\title{
Radiocarbon Dated Trends and Central Mediterranean Prehistory
}

\author{
Eóin W. Parkinson, et al. [full author details at the end of the article]
}

Accepted: 13 August 2021 / Published online: 7 October 2021

(c) The Author(s) 2021

\begin{abstract}
This paper reviews the evidence for long term trends in anthropogenic activity and population dynamics across the Holocene in the central Mediterranean and the chronology of cultural events. The evidence for this has been constituted in a database of 4608 radiocarbon dates (of which 4515 were retained for analysis following initial screening) from 1195 archaeological sites in southern France, Italy and Malta, spanning the Mesolithic to Early Iron Age periods, c. 8000 to 500 BC. We provide an overview of the settlement record for central Mediterranean prehistory and add to this an assessment of the available archaeological radiocarbon evidence in order to review the traditional narratives on the prehistory of the region. This new chronology has enabled us to identify the most significant points in time where activity levels, population dynamics and cultural change have together caused strong temporal patterning in the archaeological record. Some of these episodes were localized to one region, whereas others were part of pan-regional trends and cultural trajectories that took many centuries to play out fully, revealing prehistoric societies subject to collapse, recovery, and continuing instability over the long-term. Using the radiocarbon evidence, we model growth rates in the various regions so that the tempo of change at certain points in space and time can be identified, compared, and discussed in the context of demographic change. Using other published databases of radiocarbon data, we have drawn comparisons across the central Mediterranean to wider prehistoric Europe, and northern Africa. Finally, we include a brief response to the synchronously published but independently developed paper (Palmisano et al. in J World Prehist 34(3), 2021). While there are differences in our respective approaches, we share the general conclusions that large-scale trends can been identified through meta-analyses of the archaeological record, and these offer new perspectives on how society functioned.
\end{abstract}

Keywords Italy $\cdot$ France $\cdot$ Malta $\cdot$ Mediterranean $\cdot$ Mesolithic $\cdot$ Neolithic $\cdot$ Copper age $\cdot$ Bronze age $\cdot$ Radiocarbon dating $\cdot$ Palaeodemography

\section{Riassunto}

Il presente contributo esamina la presenza di trends nei livelli di attività antropiche e nelle dinamiche popolazionistiche del Mediterraneo centrale durante l'Olocene. I dati 
consistono in un database di 4608 datazioni al radiocarbonio provenienti da 1195 siti archeologici dalla Francia meridionale, dall'Italia e da Malta, che coprono un arco cronologico che va dal Mesolitico all'Età del Ferro (8000-500 a.C. circa). A seguito di uno screening iniziale, 4515 datazioni al radiocarbonio sono state selezionate per l'analisi finale. Si fornisce una panoramica generale sulla preistoria del Mediterraneo centrale assieme a una valutazione delle datazioni archeologiche al radiocarbonio al fine di rivalutare le interpretazioni tradizionali sulla preistoria dell' area analizzata. Questo approccio ha consentito di identificare i momenti più significativi nei quali i livelli di attività antropica, le dinamiche popolazionistiche e i cambiamenti culturali hanno congiuntamente causato forti patterns temporali nel record archeologico. Alcuni di questi fenomeni sono circoscritti a una singola regione, mentre altri fanno parte di tendenze pan-regionali e traiettorie culturali che hanno richiesto molti secoli per essere pienamente realizzate, mostrando società preistoriche soggette a collasso, ripresa e continua instabilità nel lungo periodo. Utilizzando le datazioni al radiocarbonio, il presente contributo propone modelli sui tassi di crescita delle diverse regioni in modo da identificare nello spazio e nel tempo momenti di cambiamento, comparandoli e discutendoli alla luce della fluttuazione demografica. L'articolo propone inoltre un confronto tra il Mediterraneo centrale, l'Europa preistorica e l'Africa settentrionale attraverso l'utilizzo di altre datazioni al radiocarbonio disponibili in letteratura. Infine, si presenta una breve risposta all'articolo sviluppato contemporaneamente ma in maniera indipendente da Palmisano et al. (2021). Anche se i due contributi presentano evidenti differenze nei rispettivi approcci, questi condividono le conclusioni generali secondo cui la meta-analisi del record archeologico può identificare tendenze su larga scala e offrire nuove prospettive sulle società antiche.

\section{Introduction}

The use of large databases of radiocarbon dates to explore past levels of anthropogenic activity and settlement patterns is an approach to archaeology that has recently gathered much momentum. Estimates have been made of past human activity and demographic fluctuations by assuming a relationship between levels of human activity or population size and the frequency with which datable material enters the archaeological record (Haynes, 1969; Rick, 1987). In this paper, we review the radiocarbon and settlement evidence for the prehistory of the central Mediterranean region, identify trends in prehistoric activity levels and settlement patterns, and discuss their potential causes in terms of demography, migration and the response to environmental change, with detailed reference to relevant archaeological context.

The prehistoric central Mediterranean (Fig. 1) comprises a rich and varied archaeological record of pronounced cultural developments within an extremely diverse physical landscape. The study of prehistory in the central Mediterranean has stood somewhat apart from wider continental traditions, with the region having been historically divided into distinctive sub-regional academic traditions split between the natural sciences and more humanities-leaning approaches (Guidi, 2010). As a consequence of these localized research traditions, the application of archaeological science has been far more widespread in the central-northern Italian peninsula 
A

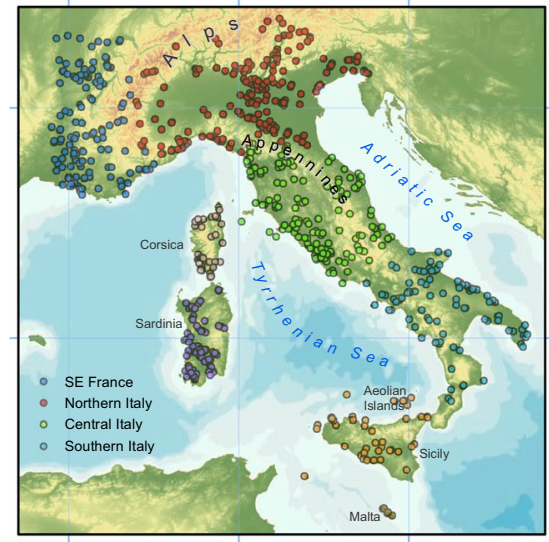

B

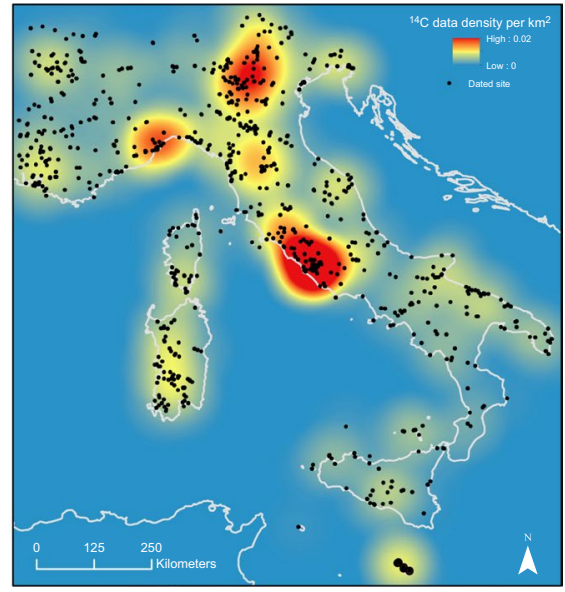

Fig. 1 Maps showing: a the topography of the central Mediterranean region and the location of archaeological sites included in this study; and $\mathbf{b}$ spatial density of radiocarbon dates in the study

than in southern Italy and the surrounding islands. Chronology building in the central Mediterranean has traditionally been focused on developing typo-chronologies of ceramic styles and artefacts, resulting in an extremely refined relative chronology. However, whilst traditional typo-chronologies have both practical and ontological uses, they often confuse and hamper broader regional syntheses and offer little insight into the timing and tempo of cultural change in prehistory. In contrast, radiocarbon evidence offers an independent opportunity to identify the absolute chronology and explore the dynamics within past human societies.

One barrier to achieving this synthesis is that the available radiocarbon evidence for the prehistoric central Mediterranean is limited in contrast to other areas of continental Europe. Although the situation has rapidly improved in recent years, the paucity of radiocarbon evidence has long been recognized as particularly problematic in Mediterranean island contexts such as Malta, Sicily and Sardinia (Burleigh, 1984). Whilst there were early attempts to draw together the radiocarbon evidence for discrete periods of central Mediterranean prehistory (Renfrew, 1971; Whitehouse \& Renfrew, 1974), a surge of research on Italian prehistory by Italian and Anglo-American researchers throughout the 1990s led to the first attempts to gather together systematically the available radiocarbon evidence for the central Mediterranean (Bagolini \& Biagi, 1990; Pluciennik, 1994; Skeates, 1994, 1996; Skeates \& Whitehouse, 1994b; Trump, 1996). The most significant contribution of all was Skeates and Whitehouse's (1994a, 1994b) volume Radiocarbon Dating and Italian Prehistory, which provided the first exhaustive list of radiocarbon dates for prehistoric Italy and serves as the foundation for our study. In recent years, a renewed focus on evaluating the radiocarbon evidence for the central Mediterranean Mesolithic (Lo Vetro \& Martini, 2016), Neolithic (Binder et al., 2017; Lugliè, 2018; Natali \& Forgia, 2018; Pearce, 2013; Skeates, 2013; Starnini et al., 2018), Copper Age (Cocchi Genick, 2013), Bronze Age (Alberti, 2013b; Capuzzo, 2014; Capuzzo 
et al., 2014) and, to a lesser extent, Iron Age (van der Plicht et al., 2009) periods has provided a strong basis on which to explore long-term regional trends in radiocarbon data. Recent studies by Palmisano et al. (2017) and Stoddart et al. (2019) have utilized a multi-proxy approach combining archaeological surveys, sites and summed probability distributions of radiocarbon dates to explore long-term demographic trends in central Italy, demonstrating the effectiveness of radiocarbon evidence as an estimate of past demography and human activity in a central Mediterranean context. Similar studies analysing large bodies of radiocarbon dates have been undertaken for elsewhere in Italy (Martínez-Grau et al., 2020; Parkinson \& McLaughlin, 2020) and the wider Mediterranean region (McLaughlin et al., 2020a; Broodbank and Lucarini, 2020; Fernández-López de Pablo, 2019; Welberg et al., 2019; Berger et al., 2019; Palmisano et al., 2019), underscoring the value of such approaches.

A further challenge in constructing regional syntheses that extend beyond modern political boundaries is terminology. Overall, a broad division of Mesolithic, Neolithic, Bronze and Iron Age applies across all the regions considered here, but the terminology related to sub-periods varies considerably between Italy, France and the Maltese Islands. This situation is further compounded by the complicated typochronologies that exist for some time periods. For example, there has been some debate over the phasing of the Italian Neolithic (see Whitehouse, 2013), with Tinè (1983) proposing a tripartite division consisting of an Early, Middle and Late phase, although including 11 sub-divisions. This was subsequently revised by Whitehouse (1986), who reshuffled the boundaries of the tripartite scheme and added a fourth Final Neolithic phase that coincided with Tinè's (1983) Late Neolithic. Whilst the initial tripartite scheme remains in use among Italian scholars (Pessina \& Tinè, 2018), the two schemes are still used interchangeably, but with a general preference among Anglo-American scholars towards Whitehouse's (1986) revision. The picture gets muddied further when we consider other, closely related, cultural sequences in the region, such as the Maltese Islands where the Early Neolithic defined by Trump (1966b) falls within the southern Italian Middle to Final Neolithic cultural setting as designated by Tinè (1983) and Whitehouse (1986). In the later Neolithic, further regional variation in terminology confuses synthesis. Most notable is the definition of the Late Neolithic and Copper Age which differs between Italy and France: where mid fourth millennium BC introduces the Copper Age, or Eneolithic, in Italy, the term 'Late Neolithic' continues in use within French literature, lasting into the third millennium BC until the onset of the Bronze Age (see Pearce, 2019 for a historical perspective on the term 'Copper Age' and the impact of regional terminologies).

The division of the central Mediterranean Bronze Age is primarily based on pottery typology and in Italy is separated into Early, Middle, Recent and Final phases, each with numeric sub-phases. On the Maltese Islands, the Bronze Age is divided into Early, Middle and Late phases, and in France into Early, Middle and Final phases. Here we aim to use the relevant regional terminologies specific to whichever region is being discussed, although by virtue of Italy's geographical dominance in the central Mediterranean, there is a general reliance on Italian chronological frameworks. A summary of the main terminologies used and a chrono-typological sequence for the central Mediterranean is offered in Fig. 2. This scheme does not, however, include numeric sub-phases (e.g. Middle Bronze Age I, Middle Bronze 


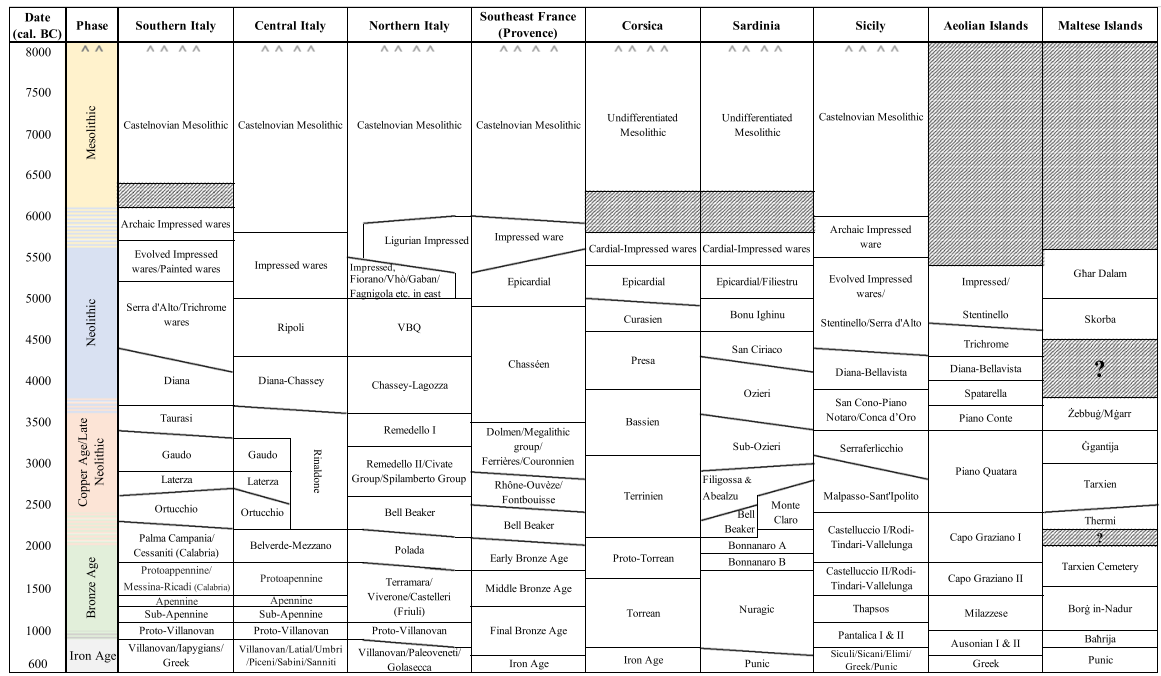

Fig. 2 Simplified relative chronology for the central Mediterranean 8000-600 cal. BC. Sub-phases not included

Age II). Ultimately, attempts to formulate such schematic views of cultural change in prehistory are fraught with challenges and will inevitably have shortcomings, but Fig. 2 is intended to provide a context for the archaeological background and radiocarbon trends discussed here.

Although Italy's landmass dominates much of the central Mediterranean-and therefore prehistoric studies in the region-the importance of considering non-Italian islands has also long been recognized (Malone, 2003; Robb, 2007; Tykot, 1994). Following Skeates' (1994) initial synthesis of radiocarbon dates for the Italian Palaeolithic to Iron Age periods, calls were made for a broader overview of the central Mediterranean that included the Maltese Islands (Skeates \& Whitehouse, 1994a; Trump, 1995), with subsequent date lists aimed at addressing this issue (Skeates, 2000a; Trump, 1996). Only in studies documenting the spread of the Neolithic across the central Mediterranean has specific attention been paid to non-Italian territories, rightly highlighting the close relationships between Sardinia and Corsica (Lugliè, 2018), Liguria and south-east France (Binder et al., 2017; Maggi et al., 2020; Pearce, 2013) and the Adriatic coast of the Italian peninsula and Dalmatia (Conati Barbaro, 2019, pp. 79-83; Forenbaher \& Miracle, 2005; Pearce, 2013, pp. 85-159) during the transition to agriculture. Such approaches have yet to be widely applied to later time periods, in particular the Bronze and Iron Ages, which are instead defined by long standing regional scholarly traditions. 


\section{Methodological Context}

The availability of large datasets and methodological developments have together transformed our ability to extract meaningful time series from aggregated radiocarbon data. Pioneering, continental-scale studies (Hinz et al., 2012; Peros et al., 2010; Shennan \& Edinborough, 2007) summed the radiocarbon dates from a region to construct a model of human activity, settlement dynamics or population levels through time. A full description of the methods, their robusticity and interpretation, is provided in the Methods section of the paper and more detail is given in the online Supporting Information. Although this approach to the archaeological record has incurred some criticism (Attenbrow \& Hiscock, 2015; Carleton \& Groucutt, 2021; Contreras \& Meadows, 2014; Torfing, 2015), further developments in simulation and bootstrapping have introduced methods that deal with calibration noise and enable identification of points in time where activity levels significantly deviate from null models of uniform or exponential growth (Carleton \& Groucutt, 2021; Timpson et al., 2014). More recently, methods for formally testing the difference in activity and dynamics at various co-ordinates in time or space have been published (Crema et al., 2017; Edinborough et al., 2017) and, as discussed below, kernel density estimation (KDE) is a useful alternative to summed probability modelling for archaeological data (Bronk Ramsey, 2017; Brown, 2017; McLaughlin, 2019).

Recently published case-studies dealing with large-scale meta-analysis of radiocarbon data are now moving beyond methodological development, and instead seek to frame cultural evolution and population history within specific questions of, for example, continuity (Morin et al., 2018), oral traditions (Edinborough et al., 2017), climate and landscape change (Jørgensen, 2018), and economic history (McLaughlin, 2019). These studies, combined with discussions about what aggregated radiocarbon data actually mean in terms of past activity (Freeman et al., 2018), represent a considerable theoretical movement within archaeology, but a timely one given the renewed interest in past demography engendered by studies of ancient DNA. Irrespective of its methodological and theoretical approach, the current study is an expansion of work already completed for prehistoric central Italy (Palmisano et al., 2017, 2018), south-eastern France (Berger et al., 2019) and central-southern Europe in the Bronze Age (Capuzzo et al., 2018), and has been undertaken in the wider context of a burgeoning number of detailed, time-series-based syntheses of the archaeological record from macro-regions as diverse as Korea (Oh et al., 2017), Peru (Riris, 2018), North America (Zahid et al., 2016), and the British and Irish Isles (Bevan et al., 2017). We aim to contribute to this larger effort of systematically organizing archaeological information and uncovering new insights into large-scale patterns in world history. 


\section{Archaeological Context}

\section{The Mesolithic}

The evidence for human activity during the Mesolithic period in the central Mediterranean (c. 9700 to $6000 \mathrm{BC}$ ) varies by sub-region. On the Italian peninsula, Mesolithic settlement largely occurred in caves and rock-shelters and is broadly characterized by the earlier 'Sauvetterrian', and later 'Castelnovian' lithic industries (or the 'first' and 'second' Mesolithic in French literature), whilst the surrounding islands are associated with undifferentiated lithic traditions (see Lo Vetro \& Martini, 2016). Northern Italy has a particularly well-documented Mesolithic, and settlement evidence demonstrates use of both lowland and upland or mountainous territories (see Fontana \& Visentin, 2016), with sites known in the Trieste Karst, Adige Valley, Tuscan-Emilian and eastern Ligurian Apennines, and Po Plain (Biagi et al., 1988; Franco, 2016; Kompatscher et al., 2016; Scoz et al., 2015; Visentin \& Carrer, 2017; Visentin et al., 2014, 2016). In central and southern Italy, local terrestrial and marine resources appear to have been exploited in a pattern consistent with the seasonal utilization of coastal caves and rock-shelters (Lo Vetro \& Martini, 2016). In general, however, earlier Mesolithic settlement in the south shows particular focus on coastal areas, as on the Salento peninsula in Puglia, in contrast to greater exploitation of inland areas in central (Pluciennik, 2008) and northern Italy (Fontana et al., 2013).

Among the islands of the central Mediterranean, Sicily has some of the most important Mesolithic sites. A cluster of well-studied cave sites with Mesolithic occupation and burial is known in north-west Sicily (D'Amore et al., 2010a, 2010b; Lo Vetro \& Martini, 2016; Lo Vetro et al., 2016; Tagliacozzo, 1994), whereas in southern Sicily the comparative dearth of Mesolithic activity (Martini et al., 2007) resembles the situation in the Maltese Islands, which have no evidence for Mesolithic occupation (Bonanno, 2000). In Sardinia and Corsica, the Mesolithic period is similar to that of peninsular Italy, although marked differences that stem from the natural isolation of the two islands are reflected in the archaeological record. Settlement of the Tyrrhenian islands is defined by shortterm and discontinuous occupation of small coastal rock-shelters (Costa et al., 2003; Lugliè, 2009a), although Mesolithic presence in larger caves is documented in Sardinia (Lugliè, 2009a, 2018). The Mesolithic economy of Sardinia and Corsica reflects exploitation of local terrestrial and marine resources, with a significant reliance on the endemic small mammal Prolagus sardus (Vigne, 1998). It has been suggested that, taken together, the evidence indicates short-term seasonal visits to the islands by small sea-faring groups from the Italian mainland (Costa et al., 2003).

The end of the Mesolithic was also regionally varied. In southern and central Italy, there appears to be a clearer chronological gap between the last Mesolithic hunter-gatherers and the arrival of the first Neolithic farmers (Perrin \& Manen, 2021; Pluciennik, 1997), while the situation is considerably more varied in the north. Along the northern cost of the Tyrrhenian Sea, an area without any late 
Mesolithic sites spanning western Liguria and eastern Provence lies between the Rhône valley and the eastern Ligurian Apennines where later Mesolithic sites are documented (Battentier, 2018; Biagi et al., 1988; Maggi et al., 2020). This distinctive pattern of late Mesolithic activity appears to have had a major bearing on the settlement pattern of northern Italy's earliest Neolithic pioneers, who spread along coastal routes, favouring areas without Mesolithic hunter-gatherers (see below). In the rest of northern Italy, along the Po and northern Apennines, the available radiocarbon data reveal a much murkier picture, and it is difficult to prise apart the relationship - and potential interactions-between the earliest farmers and last hunter-gatherers in the region (Martínez-Grau et al., 2020; Pearce, 2013, pp. 159, 204-207; Perrin \& Manen, 2021).

\section{The Neolithic}

The transition to agriculture in the central Mediterranean in the run-up to the sixth millennium BC brought with it technological innovations, new belief systems, domesticated animals and traditional 'Neolithic package' crops (Guilaine et al., 2019; Malone, 2003; Ucchesu et al., 2017). The earliest Neolithic settlements in Italy associated with impressed-ware ceramics have been found along the lowland coastal areas of south-east Italy on the Salento peninsula and Tavoliere of Apulia (Brown \& Alexander, 2013; Natali \& Forgia, 2018). The region is perhaps best known for its many large ditch-enclosed settlements (villaggi trincerati) (Delano Smith, 1978; Jones, 1987), and with some 774 such sites of varying size documented on the Tavoliere alone (Whitehouse and Hamilton, 2020, p. 163), the Neolithic of southern Italy marks a point of major population increase and settlement density. The majority of ditched villages consisted of small groups of ditch-enclosed farmsteads set within larger perimeter ditches spanning areas of 4-7 hectares, but megasites such as Passo di Corvo reached up to 130 ha (Tinè, 1983; Trump, 1987, pp. 118-129). The Neolithic then rapidly spread westward into Calabria (Morter, 2010) and Sicily (Leighton, 1999, pp. 66-74; Natali \& Forgia, 2018). In Sicily, Neolithic settlement was contained within caves and in open-air ditched village sites along the northern and southern coasts. Most of the known Sicilian open-air villages were excavated in the late nineteenth and early twentieth century along the south-eastern coast of the island (Orsi, 1899, 1921) and have received little attention since. Only a few later village sites located further west, such as at Stretto-Partanna and Piano Vento, have undergone more systematic investigation (Castellena, 1985; Martínez Sánchez et al., 2016). Most of our understanding of the Early Neolithic in Sicily therefore stems from two cave sites in western Sicily-Grotta dell'Uzzo and Grotta d'Oriente-where transitional Neolithic-Mesolithic stratigraphy has been identified (Tagliacozzo, 1994; Lo Vetro and Martini, 2016).

The spread of the Neolithic to central and northern Italy can be viewed as a series of parallel maritime expansions along the Adriatic and Tyrrhenian coastlines, including Sardinia and Corsica (for detailed discussion see Pearce, 2013, pp. 21-158). The speed at which agriculture spread northwards is demonstrated by the extremely early introduction of the Neolithic to western Liguria and eastern 
Provence by as early as 5900 cal. BC (Binder et al., 2017; Maggi et al., 2020). In Adriatic central and northern Italy, where the spread of agriculture was intertwined with its spread along the adjacent eastern Adriatic coasts of Albania, Montenegro and Croatia (Conati Barbaro, 2019, pp. 71-83; Ferrari et al., 2018; Forenbaher \& Miracle, 2005), the Neolithic arrived several centuries later (Martínez-Grau et al., 2020). This combination of routeways for the spread of the Neolithic into northern Italy resulted in the development of regionally distinct cultural traditions that can be divided between the north-western Italian Ligurian Impressed wares, and the Vhò, Fiorano, Gaban and Fagnigola groups to the east across the Po and Alpine valleys (Starnini et al., 2018). In central Italy, Early Neolithic settlements are found in subcoastal areas and lowlands on terraces overlooking rivers and lakes (Conati Barbaro, 2019, p. 13; Fugazzola Delpino et al., 2003a, pp. 94-99; Radi et al., 2018; Malone et al., 1992), whereas the settlement pattern in the north is one of cave and rock-shelters in the west and open-air villages in the east (Bagolini, 1980; Pessina $\&$ Tinè, 2018), further echoing the west-east differentiation in cultural traditions for the North Italian Neolithic.

In Sardinia, the arrival of the Neolithic around 5800-5600 cal. BC also saw complete genetic and cultural discontinuity with the preceding Mesolithic, as attested by stratigraphic information from Grotta Su Coloru (Lugliè, 2009b, 2018), radiocarbon data (Perrin et al., 2021), and aDNA studies (Modi et al., 2017). Together with the suggestion that Mesolithic activity on Sardinia and Corsica may have been restricted to occasional visits by groups from the Italian mainland (see above), this may therefore indicate that the Tyrrhenian islands were largely-if not entirely-depopulated by the time the earliest Neolithic settlers arrived. Following an initial Neolithic pioneer phase, the Neolithic in Sardinia signalled a period of significant settlement expansion, as indicated by the number of archaeological sites especially on the west coast, whilst, by contrast, Early Neolithic expansion in Corsica was more muted (Lugliè, 2009b, 2018).

Narratives of the Middle and Late Neolithic describe how gradual economic diversification and pastoralism occurred in increasingly dispersed and varied settlement contexts (Barker, 1999, pp. 13-14; Dolfini, 2020, p. 515; Malone, 2003, p. 299). Whereas areas of previous intense human occupation in southern Italy and Sicily-namely the Tavoliere and Catania plains-declined (Leighton, 1999, pp. 53-54; Fiorentino et al., 2013; Skeates, 2015; Whitehouse, 2013), there was expansion into a variety of upland and lowland areas, but also into small islands. The Maltese archipelago was settled by $5500 \mathrm{cal}$. BC, with occupation in both caves (Despott, 1917) and open-air settlements (Brogan et al., 2020; McLaughlin et al., 2020b, pp. 154-155; Trump, 1966b, 2015). In the larger islands of Sardinia and Corsica, Middle and Later Neolithic human occupation spread into a range of inland and coastal lagoon areas (Dyson \& Rowland, 2007, pp. 36-37). Within central Italy, Middle and Late Neolithic settlement continued in subcoastal areas but also penetrated further inland to the Apennine valleys and wetland areas (Fugazzola Delpino et al., 2003a, pp. 97-99; Malone, 1994, 1994a, 1994b, pp. 67-80). A similar situation occurred further north, with open-air settlement expansion into wetland zones and into the upland Alpine and Apennine areas (Mottes et al., 2009; Skeates, 2013, p. 8; Visentini, 2006). 


\section{The Final Neolithic and Copper Age}

The fourth and third millennia $\mathrm{BC}$ broadly correspond to the Copper Age in the central Mediterranean (Final or Late Neolithic in French and Maltese literature) and are defined as a period of social and economic transformations which developed out of the later Neolithic. The settlement record for the Italian Final Neolithic and Copper Age is spotty at best, but in general the period saw a movement away from nucleated villages towards more dispersed settlement into a wider variety of landscape settings (Dolfini, 2015, pp. 30-33, 2020, p. 517) and continued expansion into upland zones-where the latter narrative has been driven further by the discovery of the Tyrolean Iceman in the Ötztal Alps (Barfield, 1994b; Spindler, 2000). Traditionally, the lack of open-air settlement for Copper Age Italy was explained within the mid-twentieth-century culture-historical framework as evidence that the period was characterised by nomadic 'warrior pastoralists' who migrated into the central Mediterranean and introduced metal working into the region (Trump, 1966a, pp. 79-80; see Robb, 2007, p. 288; Dolfini, 2020, p. 524). Barker (1981a) was the first to argue against the 'warrior pastoralist' narrative, and discoveries of numerous settlements over the last 20 years (largely thanks to developer-led archaeology) further refute the long-held view that Copper Age settlement was ephemeral and suggest that the role of transhumant pastoralism during the period has been over-emphasized (Cardarelli, 2015, pp. 154-156). Settlement evidence for the central Mediterranean Copper Age has changed drastically, particularly in the central-southern Italian peninsula (Anzidei et al., 2007; Baioni \& Poggiani-Keller, 2013; Giola et al., 2007; Tunzi et al., 2013), and several substantial domestic sites indicate that larger stable settlements endured throughout the Copper Age (Anzidei et al., 2016; Bernabò Brea et al., 2011; Fugazzola Delpino et al., 2003b; Manfredini, 2014; Salerno and Marino, 2011). Many Italian sites also show continuity from the Late Neolithic to the Early Bronze Age (Baioni \& Poggiani-Keller, 2013; Fugazzolo Delpino et al., 2003a, p. 101; Ingravallo, 1980; Silvestrini \& Pignocchi, 1997; Talamo, 2006), suggesting relative homogeneity in settlement patterns throughout the fourth and third millennia BC.

The north Italian Copper Age was traditionally associated with the Remedello culture that extended across the Po Valley (Barfield, 1971). As is the case with much of the central Mediterranean, systematic research in recent decades has shown that the archaeological record is in actual fact considerably more nuanced (De Marinis, 1997). To the south of the Po River, inhumation cemeteries and settlements are found associated with the Spilamberto Group (Bagolini, 1981; Miari, 2014; Miari \& Benazzi, 2018; Miari et al., 2017) and to the north the Civate Group is known from burial in caves and statue menhirs in the Alpine regions (Barfield, 1983). Copper Age settlement in northern Italy appears on fluvial terraces and on the slopes of the pre-Alps, where multi-stratified sites demonstrate long occupation histories spanning the duration of the Copper Age (e.g. Lovere-Colle del Lazzaretto and Monte Covolo in Lombardy: Baioni \& Poggiani-Keller, 2013). Similarly long occupation spans also occur in the inner Alpine valleys, as at Latsch, Vinschgau (Festi et al., 2011), which are exploited from the Late Neolithic onwards (Putzer et al., 2016). Copper Age settlements also occurred on the southern Po Plain, with some focus on 
the margin of the Apennines in Emilia-Romagna (Bernabò Brea et al., 2011; Berni et al., 2011; Miari, 2014).

The Rinaldone culture traditionally defined the central Italian Copper Age (Trump, 1966a, pp. 72-80), although recent research has shown the complex spatial and temporal relationship between Italy's traditional Copper Age 'cultures' in central and southern Italy (see Fig. 2). Areas such as the 'core' Rinaldone zone on the Tuscany-Latium border still lack definitive settlement evidence (Fugazzola Delpino et al., 2003a, pp. 100-101), but a large number of sizeable cemetery sites suggests considerable population increase during this period (Negroni Catacchio, 2006; Negroni Catacchio et al., 2016). Some of the most important developments have occurred in the area south of Rome, where excavations have uncovered extensive evidence for Copper Age settlement in the area between the Tiber river and the Colli Albani and redefined the entire Copper Age sequence for central-southern Italy (Anzidei et al., 2007, 2012, 2016; Carboni \& Anzidei, 2013; see Anzidei \& Carboni, 2020) by revealing the complicated spatial and temporal relationships between the Rinaldone, Gaudo, Laterza and Ortucchio ceramic styles (Fig. 2). The RomaColli Albani sites indicate dense and stable settlement in southern Rome from the mid fourth to late third millennia BC, alongside continuity in economy and burial traditions across the entire Late Neolithic and Copper Age sequence. On the Adriatic coast of central Italy, Copper Age activity is known in Marche along the narrow coastal plains surrounding Ancona and into the Apennines, with funerary sites situated towards the coast and settlement located inland (Fugazzola Delpino et al., 2003a, p. 101; Manfredini et al., 2009; Skeates, 1997). Large open-air villages are also known in Marche at Conelle di Arcevia (Cazzella \& Moscoloni, 1999; Cazzella \& Recchia, 2014) and Maddalena di Muccia at Macerata (Manfredini, 2014) and attest to the existence of substantial and stable Copper Age settlement here too.

The southern Italian Copper Age was until recently known solely from large rockcut tomb cemeteries associated with the Gaudo culture in Campania and the Laterza culture in Apulia (Biancofiore, 1967; Whitehouse \& Renfrew, 1974, pp. 349-357). The Roma-Colli Albani sites mentioned above have highlighted the complexities of the Copper Age in southern Italy too, extending the distribution of Gaudo and Laterza ceramic styles to central Italy, and as actually reflecting chronologically discrete cultural horizons-Gaudo representing the middle Copper Age and Laterza representing the recent Copper Age (Carboni, 2020a, p. 89, 2020b; Carboni \& Anzidei, 2013, pp. 149-161; Fig. 2). The recent introduction of a new earlier Taurasi phase associated with cremation cemeteries in Campania (Passariello et al., 2010), Apulia and Basilicata (Aprile et al., 2013; Quarta et al., 2014), further demonstrates the true complexity of the south Italian Copper Age. In Campania, Middle Copper Age settlements from the early third millennium BC are situated on the fertile coastal plain north of Naples (Aurino, 2013). At the settlement of Caivano, two successive phases of occupation associated with the Gaudo culture were separated by the Agnano 3 eruption horizon (Passariello et al., 2010), demonstrating a rapid reoccupation of the area following the event. The settlement record for later prehistory in Campania also shows general consistency from the Late Neolithic to Early Bronze Age, with settlements known in both lowland and upland areas, with those in the highlands appearing to relate to the control of natural route ways (Talamo, 2006). In Apulia, Copper 
Age activity on the Tavoliere was minimal, and Final Neolithic-Copper Age settlements are found on the Murge plateau (Fiorentino et al., 2013), the Salento peninsula and Basilicata (Pacciarelli et al., 2015). The picture for the Late Neolithic and Copper Age of Apulia has started to improve in recent years, and the recent excavation of a settlement at Tegole represents a rare and important Copper Age presence on the western margin of the Tavoliere (Tunzi et al., 2013, 2017).

Turning to the islands, the Sicilian 'proto-Eneolithic' during the late fifth to early fourth millennia $\mathrm{BC}$ is largely associated with the development of rock-cut tomb cemeteries in the south related to the San Cono-Piano Notaro culture, such as Piano Vento (Castellana, 1995) and Scintilia (Gullì, 2014), and with the Conca d'Oro culture in the north (Tinè, 1960). Copper Age settlement sites in Sicily show utilization of a variety of landscape locations, and like adjacent areas of peninsular Italy, there was continuity with Late Neolithic and Early Bronze Age patterns (Leighton, 1999, p. 100). The period is characterized in general by an expansion into the uplands (Leighton, 2005), apparent in both the earlier Copper Age (Cazzella \& Moscoloni, 2012, pp. 59-62) and middle and later Serraferlicchio and later Malpasso cultural contexts (Giannitrapani et al., 2014; Malone et al., 2003). In southeast Sicily, areas of dense Early Neolithic settlement on the coastal plains surrounding Syracuse and Catania remained largely unused during the Copper Age (Leighton, 1999, pp. 89, 100), but use of cave sites for habitation, burial and cult purposes continued in the coastal areas of Agrigento in southwest Sicily (Gullì, 2011).

In the Sardinian Copper Age, it appears that Early Copper Age Sub-Ozieri and Middle Copper Age Abealuzu and Filigosa settlement shows general continuity with the Late Neolithic Ozieri phase (Melis, 2000, p. 141; Melis, 2009), which is also reflected in continuity in funerary traditions (Melis, 2014). Interpretation of the details of Copper Age settlement patterns in Sardinia should, however, proceed with some caution, given the stylistic similarities in material culture across the Late Neolithic and earlier Copper Age and the fact that most sites are known from either surface features or find scatters (Webster \& Webster, 2017, p. 57). The chronology of the Sardinian Copper Age has received much-needed attention in recent years (Melis, 2013; Melis et al., 2017), but many questions remain over the spatial and temporal interplay between cultural phases in the third millennium BC. More recently, Pearce's (2017) updated chronology (see Fig. 2) has expanded the Ozieri phase to 4200-3400 cal. BC and Sub-Ozieri to 3600-2800 cal. BC. By the early third millennium BC, the Filigosa and Abealzu phases emerged alongside the distinctive Monte Claro phase, which spanned the majority of the third millennium BC and overlapped with the Sardinian Bell Beakers (Melis, 2013, pp. 206-207). Marked differences in settlement and material culture are more apparent in Monte Claro phase contexts (Melis, 2000, p. 144), with the emergence of large villages in some cases consisting of up to 60 huts, as at Monte Pranu (Manunza et al., 2014). In general terms, Monte Claro phase settlements were primarily located on lowlands in the south and hills to the north, in contrast to the coastal settings of earlier periods (Lai, 2008, p. 102).

Finally, the fourth and third millennia BC on the Maltese Islands saw the rise of a complex culture characterized by elaborate and sophisticated megalithic 'temples', art and ritual processes that expressed a strong local identity (Bonanno et al., 
1990). The sharp cultural discontinuity between the Early Neolithic (Ghar Dalam and Skorba phases) and the Late Neolithic 'Temple Period' has been the focus of much discussion (Trump, 2002, pp. 238-241), establishing a theoretical framework that suggested cycles of relative isolation and insularity over time (Stoddart et al., 1993; Trump, 1961); this has since been challenged (Grima, 2002; Robb, 2001), and then reiterated in both cultural and biological detail (Malone \& Stoddart, 2004; Ariano et al. in press). Domestic evidence for the Temple Period on the Maltese Islands is extremely scant (Malone et al., 2009), in contrast to a wealth of ritual architecture (Trump, 2002). Aside from unconvincing arguments that subsidiary structures at megalithic sites represent huts (Sagona, 2015, pp. 55,78), only two Temple Period domestic structures have been excavated in the archipelago, both on the smaller island of Gozo (Malone et al., 1988, 2020a).

\section{The Bronze Age}

The Italian Bronze Age has been divided into four phases, Early, Middle, Recent and Final. Traditions of scholarship dictate that the Bronze Age of northern Italy has been studied in the context of its close ties with broader continental Europe (Barfield, 1994a). The north Italian Early Bronze Age is represented by the Polada culture, noted for numerous lake settlements distributed along the southern Alps, particularly along Lake Garda, and limited settlement on the Po Plain (Barfield, 1994a; Capuzzo, 2014; Nicolis, 2013). This settlement pattern changed greatly throughout the mid second millennium BC in the Middle Bronze Age, which was marked by the rise of the Terramare system. The Terramare was accompanied by a dense settlement shift to the central-southern Po Plain and considerable population increase (Bernabò Brea et al., 2018; Vanzetti, 2013), which reached a peak at the turn of Middle Bronze Age and Recent Bronze Age (Cardarelli, 2009, p. 468). The Terramare settlements were essentially planned villages of pile-built houses that were serviced with drainage and enclosed within quadrangular banks (Pearce, 1998). By the Recent Bronze Age, the Terramare settlements had become more complex, showing greater monumentality in their earthworks, which implies a necessity for defence, alongside technological advancements in metallurgy and agriculture (Bernabò Brea et al., 1997; Blake, 2014).

A subsequent decline of the Terramare system led to an eventual collapse at the end of the Recent Bronze Age (Cardarelli, 2009, p. 485); however, this collapse was not universal, since some Terramare north of the Po River continued into the Final Bronze Age (Cupitò et al., 2015). The decline of the Terramare is associated with a large-scale demographic collapse (Cardarelli, 2009; Rondelli, 2008), caused by a variety of factors, including environmental decline and climatic deterioration (Cremaschi et al., 2006, 2016; Whitehouse, 2001) or social and political instability (Cardarelli, 2009, p. 471). Overall, the region inhabited by the Terramare group has limited evidence for much of the Final Bronze Age and Early Iron Age (Barfield, 1994a), with the exception of the Valli Grandi Veronesi sites (Cardarelli, 2009, p. 506). A similar abandonment of Recent Bronze Age settlements is attested in other areas of the Peninsula, such as the Romagna plain (Von Eles \& Pacciarelli, 
2018) and a substantial part of the Marche region (Cardarelli, 2009, p. 507). Recent authors (Pearce, 2020; Stoddart, 2020c; Zamboni, 2021) have also sought to consider the extent to which the Terramare actually reflected a form of 'fragile' protourbanism in the later Bronze Age that deviated from the typical model of Mediterranean urbanisation, which revolved around long established centres.

Central Italy is an example of this 'typical' process, where the Bronze Age is defined by gradual development in social and political complexity that ultimately led to state development in the Iron Age (Bietti Sestieri, 2010, pp. 356-358; Pacciarelli, 2000; Stoddart, 2020a, 2020b). Although interpretation must proceed with caution because of the methodological and geographical biases implicit in the data (Stoddart, 2020a, pp. 13-22), central Italy is nonetheless the best-resolved Italian region. Most of the work has been concentrated on South Etruria (Northern Lazio) (Barbaro, 2010; Di Gennaro, 1986; di Gennaro \& Pacciarelli, 1992), Latium vetus (Southern Lazio), the area close to Rome (Cardarelli, 2018), and the Marche on the Adriatic coast (Cardarelli et al., 2017), although notable exceptions such as Gubbio, in Umbria, have some of the highest densities of pottery in the region (Malone and Stoddart, 1994).

The social and political transformations of the Bronze Age were clearly accompanied by an increase in archaeological sites and population (Barker, 1999; Barker \& Stoddart, 1994), which has been corroborated by the available radiocarbon evidence (Palmisano et al., 2017). Settlement patterns for the Early and Middle Bronze Age of central Italy show occupation of both upland and lowland areas as part of a mixed economy (Barker, 1981b, 1999, 2005). The Recent Bronze Age in Italy corresponds to a period of profound social and political change, and it has been argued that it is under-represented in the archaeological record, especially through surface survey (Barker \& Stoddart, 1994). This pattern of demographic growth continued to develop into the Final Bronze and is associated with a general increase in sites, in contrast to northern Italy. Increased density of settlements and associated cemeteries in South Etruria during the Final Bronze Age has also been interpreted as evidence for increasing social hierarchy (Barbaro, 2010; di Gennaro \& Barbaro, 2008) and cultural homogeneity, recognized as Proto-Villanovan material culture and latter attested in a significant part of the Italian peninsula (Negroni Catacchio, 2010). A further profound change took place at the transition to the Iron Age in Etruria, when settlement concentrated on larger plateaux or alternatively neighbouring hills with a significant extension of 125-180 ha or 40-90 ha in case of smaller centres (Pacciarelli, 2000, p. 279); in some cases (e.g., Tarquinia) these were already occupied from the last phase of the Final Bronze Age (Bietti Sestieri, 2010). There has been much discussion regarding the politics of how this process was accomplished, with interpretations ranging from collective action to the authority of a restricted leadership (see Stoddart, 2010; Stoddart et al., 2020).

For the southern part of the central Mediterranean, the picture of the Bronze Age is one of considerable regional diversity. Early Bronze Palma Campania villages in the south of the peninsula show varied use of settlement locations, including coastal and riverine areas, lowlands sites and mountain camps (Di Vito et al., 2019; Talamo, 1996), indicative of small societies engaged in mixed agriculture and smallscale pastoralism (Albore Livadie, 2007; Di Vito et al., 2019). Evidence from the 
exceptionally well-preserved settlement of Nola-Croce del Papa in Campania shows a reliance on ovicaprines, pig and cattle, alongside active food storage (Albore Livadie \& D'Amore, 1980; Albore Livadie and Vecchio, 2020). Traditionally, Early Bronze Age occupation of Campania was thought to have been severely impacted by the Avellino Pumice eruption of c. 1935 to 1880 cal. BC (Albore Livadie et al., 1998; Passariello et al., 2009), with some sites showing delayed reoccupation only in the Middle Bronze Age (Di Lorenzo et al., 2013; Di Vito et al., 2019), although recent research has also demonstrated considerable continuity and rapid resettlement of the area following the eruption (Albore Livadie et al., 2019).

Major sites such as Toppo Daguzzo (Basilicata) and La Starza (Campania), located between environmental zones on communication routes, seem positioned as important or central places (Malone et al., 1994a, 1994b). Excavations at Poggiomarino, Campania, have revealed a significant wetland site that was established during the Middle-Late Bronze Age and persisted into the Iron Age (Albore Livadie et al., 2010; Price, 2013), showing the presence of large and complex settlements in southern Italy during the second millennium BC, echoing the pattern known from further north. During the Middle Bronze Age, settlement is variable throughout southern Italy although there is significant use of cave sites and shelters for ritual, funerary and seasonal purposes, one of the most significant being the Grotta Cardini di Praia (Bietti Sestieri, 1997). Sites on the coast are also widespread, particularly in the Adriatic and Ionic regions, whilst fortified sites in Apulia, such as Roca Vecchia and Coppa Nevigata (Alberti, 2013b), and Broglio di Trebisacce in the Sibaritide (Peroni and Trucco, 1994), may have been connected with increased maritime trade at the time. In the Late Bronze Age, a pattern similar to that of central Italy occurred, in that the numbers of sites increased, and focus shifted to sites in naturally defensible locations (Malone et al., 1994a, 1994b).

The Sicilian Early Bronze Age is represented by the Castelluccio phase when settlement expanded to defended sites located inland, associated with increasing pastoralism, and some coastal settlements (Malone et al., 1994a, 1994b; Leighton, 1999, p. 114, 2005). On the Aeolian Islands, as the Early Bronze Age Capo Graziano phase progressed, there was a shift to settlement on higher ground (Alberti, 2013a; Leighton, 1999). On Malta and Gozo, the transition from the Temple Period to the Bronze Age now appears to be characterised by the appearance of an intermediate 'Thermi ware' phase and a subsequent hiatus before the start of the Early Bronze Age Tarxien Cemetery phase (McLaughlin et al., 2020a, 2020b, p. 33), when levels of activity on the islands are much reduced. For Sardinia, the defining feature of the Bronze Age is the Nuragic period (Lilliu, 1963; Webster, 2015), which saw a massive population increase and settlement expansion across the island. The Nuragic period is defined by its eponymous architectural feature, the nuraghe, consisting of a large conical tower, with later nuraghi featuring multiple towers and a large number of subsidiary structures. Early Nuragic sites, or proto-nuraghi, tend to be distributed in western-central Sardinia, north of Cabras (Demurtas \& Demurtas, 1992), before the tradition expanded across the entire island. As the Nuragic period developed during the Middle to Recent Bronze Age, settlements increased in number, size, and elaboration, culminating in complex nuraghi (Depalmas, 2009a,2009b,2009c; Melis, 2017), such as at Su-Nuraxi/Barumini. With an estimated 7000 nuraghi found across Sardinia (Klob, 2005), the Bronze Age in Sardinia is seen as a period of considerable population increase, similar to northern 
Italy. Although nowhere else hosts such elaborate sites in such high densities, parallel traditions to the nuraghi occur in other western Mediterranean islands, such as the Torre of southern Corsica (Peche-Quilichini \& Cesari, 2017), Sesi in Pantelleria (Orsi, 1899) and Talayots on the Balearic Islands (Gili Suriñach et al., 2006). In the Maltese Islands, villages associated with the Middle Bronze Age Borg in-Nadur phase were located within large walled enclosures that also recall this wider tradition (Evans, 1971; Tanasi and Vella, 2011).

\section{The Iron Age and the End of Prehistory}

The end of the prehistoric period in the central Mediterranean was a complex set of transformations brought about by the indigenous development of pre-Roman Iron Age states in central Italy (Pacciarelli, 2000; Perego \& Scopacasa, 2016; Peroni, 2000; Stoddart, 2020a, 2020b, 2020c), increasing presence of Phoenician and Greek colonies in southern Italy, Sicily, Sardinia and the Maltese Islands, and Italic and, later, Gallic settlement of the northern parts of the central Mediterranean region. The cultural homogeneity that characterized the Final Bronze Age then dissolved, giving way to distinct regional cultural groupings (Riva, 2010). This regional diversity, generated by special chains of networks and relationships (Bietti Sestieri, 2012; Blake, 2014; Di Gennaro, 1996), and increasing entanglement in wider worlds, also saw economic transformation and significant changes in patterns of agriculture, land use and settlement. The archaeological evidence for this period takes many forms and is not easily summarized; but in general terms there was a greater degree of long-distance trade, centralized authority, nucleated settlement and technological sophistication than in any preceding period. From this patchwork of independent, and sometimes competing social units, Rome in the eighth Century BC rose to dominate first central Italy, then the entire central Mediterranean region, culminating in a civilization that spanned much of Europe, North Africa and the Middle East. Rome's political and cultural legacies were so pervasive that they are still strongly felt throughout the world today.

\section{Methods}

This study comprises the Italian peninsula, Sicily, Sardinia, the Maltese Islands, Corsica and southeast France spanning the Mesolithic to Early Iron Age. To investigate regional trends, we divided the Italian peninsula into separate northern, central and southern areas using modern regional borders. Whilst the use of modern administrative and political borders may not seem ideal in a prehistoric context, they do broadly correspond to landscape features across the Italian peninsula and therefore have useful heuristic value.

A database of radiocarbon dates for prehistoric Italy was compiled through the aggregation of existing databases (McLaughlin et al., 2020a; Palmisano, et al., 2017; Pearce, 2013; Pinhasi et al., 2005; Skeates \& Whitehouse, 1996; Skeates, 1994, 
Table 1 The number of archaeological sites and radiocarbon dates retained for analysis for the present study, and their spatial density

\begin{tabular}{lccclc}
\hline Region & No. sites & No. dates & Area, $\mathrm{km}^{2}$ & Sites $/ 100 \mathrm{~km}^{2}$ & Dates $/ 100 \mathrm{~km}^{2}$ \\
\hline SE France & 264 & 565 & 94,000 & 0.28 & 0.60 \\
Northern Italy & 350 & 1566 & 120,000 & 0.29 & 1.31 \\
Central Italy & 266 & 1047 & 60,000 & 0.44 & 1.75 \\
Southern Italy & 133 & 501 & 123,000 & 0.10 & 0.41 \\
Corsica & 47 & 185 & 8680 & 0.54 & 2.13 \\
Sardinia & 79 & 263 & 24,090 & 0.33 & 1.09 \\
Sicily & 47 & 233 & 25,711 & 0.18 & 0.90 \\
Malta & 9 & 155 & 316 & 2.85 & 49.10 \\
Total & 1195 & 4515 & 455,797 & 0.26 & 0.99 \\
\hline
\end{tabular}

The most sparsely dated region is Southern Italy

Table 2 Numbers of radiocarbon dates from the various categories of sample per region

\begin{tabular}{|c|c|c|c|c|c|c|c|c|c|c|c|}
\hline Region & A & B & $\mathrm{C}$ & $\mathrm{D}$ & $\mathrm{H}$ & $\mathrm{R}$ & $\mathrm{O}$ & S & $\mathrm{Sc}$ & $\mathrm{U}$ & W \\
\hline SE France & 6 & 91 & 324 & 4 & 12 & 0 & 10 & 1 & 9 & 8 & 97 \\
\hline N. Italy & 52 & 54 & 670 & 1 & 298 & 0 & 8 & 14 & 41 & 242 & 186 \\
\hline C. Italy & 23 & 36 & 353 & 0 & 244 & 10 & 17 & 22 & 19 & 182 & 141 \\
\hline S. Italy & 25 & 49 & 186 & 0 & 57 & 0 & 2 & 11 & 36 & 130 & 5 \\
\hline Corsica & 0 & 12 & 105 & 0 & 2 & 0 & 1 & 0 & 0 & 65 & 0 \\
\hline Sardinia & 11 & 56 & 59 & 0 & 22 & 0 & 0 & 2 & 1 & 110 & 2 \\
\hline Sicily & 18 & 8 & 124 & 0 & 6 & 0 & 0 & 2 & 9 & 65 & 1 \\
\hline Malta & 8 & 0 & 10 & 0 & 25 & 0 & 0 & 0 & 53 & 0 & 0 \\
\hline Totals & 143 & 306 & 1831 & 5 & 666 & 10 & 52 & 38 & 168 & 802 & 432 \\
\hline
\end{tabular}

The codes used are (A) animal bone, (B) undetermined bone, (C) charcoal, (D) bulk deposit, (H) human bone, $(\mathrm{M})$ marine (a different ${ }^{14} \mathrm{C}$ reservoir), $(\mathrm{R})$ mortar, $(\mathrm{O})$ other, $(\mathrm{S})$ short-lived plant, (Sc) domesticated cereal grain, (U) unknown, (W) wood. Marine samples (6 from Southern Italy, 4 from Central Italy, 3 from Northern Italy, 1 from Sardinia, 11 from SE France, and 16 from Sicily have been excluded from the analysis but their details are provided in the Supplementary Information, available online)

1998, 2000a, 2003; Trump, 1996), and a literature review (see supplementary data). The database was imported into various Geographical Information Systems (ArcGIS 10.5, QGIS 3.4, GRASS 4.1 and maptools 0.9) for visualization and analysis. Spatial density was computed using a two-dimensional kernel density estimator with a search radius of $100 \mathrm{~km}$.

Each entry in the database consisted of a radiocarbon age determination $\left({ }^{14} \mathrm{C}\right.$ yrs \pm standard deviation), geographic attributes, some contextual information and details of the material that constituted the sample. The total number of dates from each region is given in Table 1 and each sample type in Table 2. These data were audited, pruning from the database 128 measurements with excessive error terms $\left(>400{ }^{14} \mathrm{C}\right.$ years) or dates that could not be unequivocally identified with human activity, such as samples of bulk sediment. Hierarchical cluster analysis was 
performed in order to identify individual unique site phases (Bevan \& Crema, 2020, see Supporting Information document p. 2), enabling the analysis to be undertaken using only one date from each site phase, thus avoiding overrepresentation of any one site (i.e. a particularly well-dated site) in the KDE models.

To process these data and develop density models on a calendar time scale, we used kernel density estimation (KDE) (Bronk Ramsey, 2017; Brown, 2017; McLaughlin, 2019). This method calculated the probability density of radiocarbon activity in each region with a fixed bandwidth of 75 years - the bandwidth being a smoothing parameter intended as a model of sampling error. For detailed study of rapid changes in the density models, we re-calculated them using a bandwidth of 30 years. By bootstrapping thousands of individual KDE models built from repeated 'Monte Carlo' random samples drawn from the posterior probability densities of each calibrated radiocarbon date, we were able to express in the KDE models uncertainty introduced by the radiocarbon calibration process. A relevant advantage to this approach is that radiocarbon dates with large error terms, such as the dates obtained during pioneering work in the 1960s and 1970s, can be included in the density models in a meaningful way, in contrast to summed probability approaches where the posterior probabilities of such dates are so low that they are lost among noise in the calibration curve (Brown, 2017). We repeated the density modelling process using multiple permutations of the dataset and with a sample of $50 \%$ of the dates in the database across multiple sampling runs (see Supporting Information document pp. 9-11). This process expressed a further uncertainty interval caused by the stochasticity of the data. This inherent variability, caused by archaeological factors such as site density and the average number of radiocarbon dates per site, was checked through random sampling of the data that ensures that no one site or regional research effort has undue influence over the overall results. The atmospheric or marine IntCal20 (Reimer et al., 2020) calibration datasets were used to calculate as appropriate, using rowcal (McLaughlin, 2019); for convenience in most cases the marine samples were simply excluded from the analysis, as they are so few in number (Table 2). We also performed some modelling using simulated ensembles of 'back-calibrated' radiocarbon dates to see how various modelled scenarios are represented in the radiocarbon KDE.

\section{Interpreting Kernel Density Estimation (KDE) Models}

The method used here for calculating radiocarbon kernel density models is one of a range of similar approaches that aggregate radiocarbon data and visualise their inherent trends. A KDE model can be interpreted much like a histogram representing the number of dates falling within a time slice or 'bin', which is analogous to the bandwidth of the KDE. Whilst a histogram consists of counts of dates within fixed breakpoints, the KDE is a continuous function that creates a smoothing effect that is naturally better at resolving sudden changes (Fig. 3) and is therefore our preferred means of visualising these data. Furthermore, because each calibrated date has a large range of uncertainty, bootstrapping techniques must also be employed to develop a confidence envelope for the counts of each histogram bar. As Fig. 3 

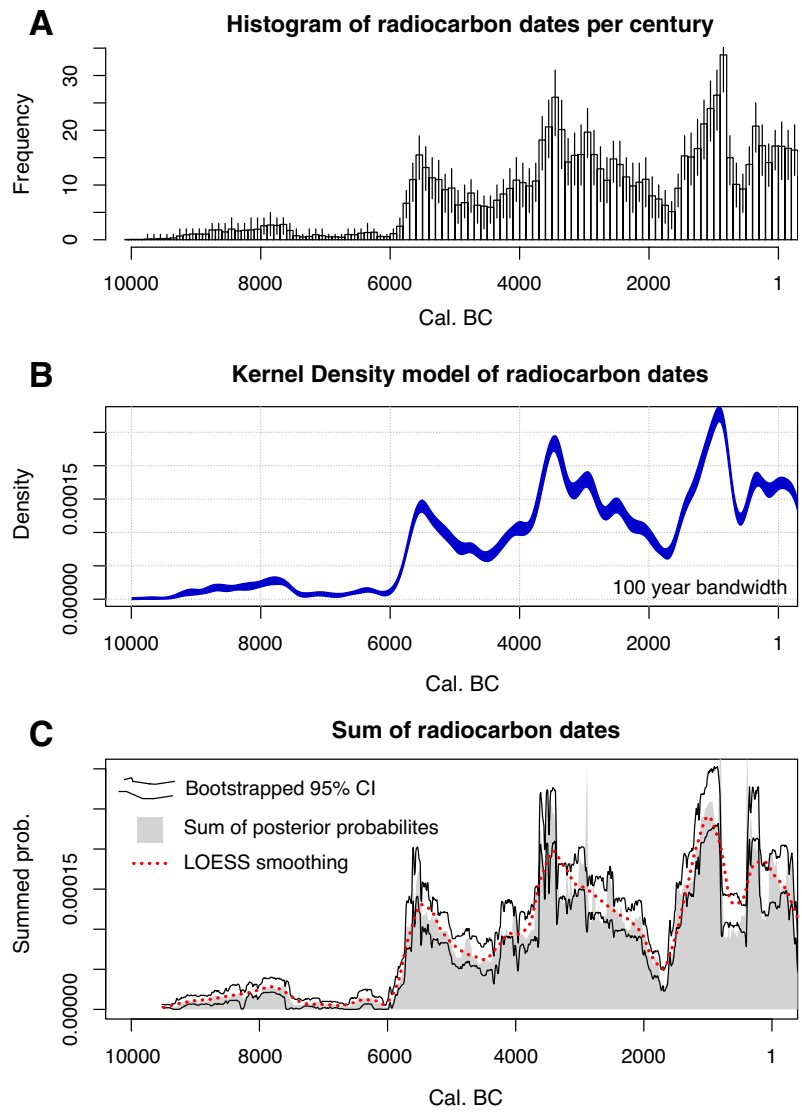

Fig. 3 A comparison of a histogram, KDE, and summed probability distribution of the same set of radiocarbon dates (in this case, the central Italian data discussed below). The confidence interval of the summed probability distribution has been calculated using the method of Fernández-López de Pablo et al. (2019)

demonstrates, not only is the uncertainty of the histogram greater, but subtleties in the data are also more difficult to identify.

A closely-related alternative is the use of summed probability distributions, which are very often used to summarize sets of radiocarbon dates. The summing approach can be criticized on the grounds that spurious artefacts are introduced into the sums via the idiosyncrasies of the calibration curve. However, the latest refinements in smoothing and bootstrapping have moved towards addressing these issues. Compared with the KDE or histogram (Fig. 3), the summed probability distributions contain more calibration noise, and although this can be removed with locallyestimated scatterplot smoothing algorithms (LOESS modelling), we prefer the KDE approach as the underlying assumptions in the smoothing model are easier to relate to real-world conditions. 
The KDEs were numerically differentiated in order to calculate annual average growth rates (see Supporting Information document pp. 21-22). The radiocarbon database, and the $\mathrm{R}$ code used to undertake the analysis are included in this paper as electronic supplementary information, which also contains some supplementary analysis and alternative projections of the data.

\section{Results}

The KDE activity models for each region in the study are plotted in Fig. 4 and animated maps showing spatio-temporal patterning of the data are included as supplementary material. The results of the KDE analysis are described in overview here, and in general show fluctuating patterns in human activity levels, with multiple periods of increase and decline in anthropogenic activity. Turning first to the Mesolithic period, represented by approximately 500 dates, the models show a constant low level of activity across the central Mediterranean (Fig. 4; see Supplementary Figure S1). The Neolithic transition, which occurred during the onset of the sixth millennium $\mathrm{BC}$, signals a period of significantly higher activity throughout the region. The beginnings of this phenomenon around $6200 \mathrm{cal}$. BC in southern Italy are associated with the initial introduction of the Neolithic into the wider central and western Mediterranean (Fig. 4, point A). This led to a pronounced apogee in activity in around the mid sixth millennium BC in southern Italy, central Italy, Sardinia, Corsica and the Maltese Islands (Fig. 4, point B). In contrast, the apex of Neolithic activity occurs later in southeast France and northern Italy during the mid fourth millennium BC (Fig. 4, point C).

The early-mid fourth millennium BC sees a modular pattern of activity across the entire central Mediterranean area at the interface between the Neolithic and Copper Age, with significant spikes occurring in both mainland areas and the islands (Fig. 4, point D). Where southern Italy and Corsica exhibit low levels of activity, the KDE models show a sharp increase in activity in Sicily, central Italy, Sardinia and southeast France during the early-mid fourth millennium BC, whilst northern Italy sees only a modest non-significant rise. In all regions, the later fourth millennium $\mathrm{BC}$ and majority of the third millennium $\mathrm{BC}$ is a period of long-term low-level stability, with the exception of the Maltese Islands, which seem to flourish at this time (Fig. 4, point D). A pronounced drop around 3000 cal. BC punctures intense anthropogenic activity in the Maltese archipelago, which is the setting for another significant peak of activity in the mid third millennium BC (Fig. 4, point E) at a time of continued subdued activity across the entire central Mediterranean. The mid third millennium BC increase observed on the Maltese Islands gradually declines and a coeval increase occurs in neighbouring Sicily, associated with the Early Bronze Age (Fig. 4, point F). Only in southeast France and northern Italy does a similar increase occur with the inception of the Early Bronze Age (Fig. 4, point F), with central and southern Italy and the Tyrrhenian islands showing no such pattern.

The development of the Bronze Age in southeast France, central Italy, Sardinia and Sicily is interrupted by a significant drop in the KDE models (Fig. 4, point G), 

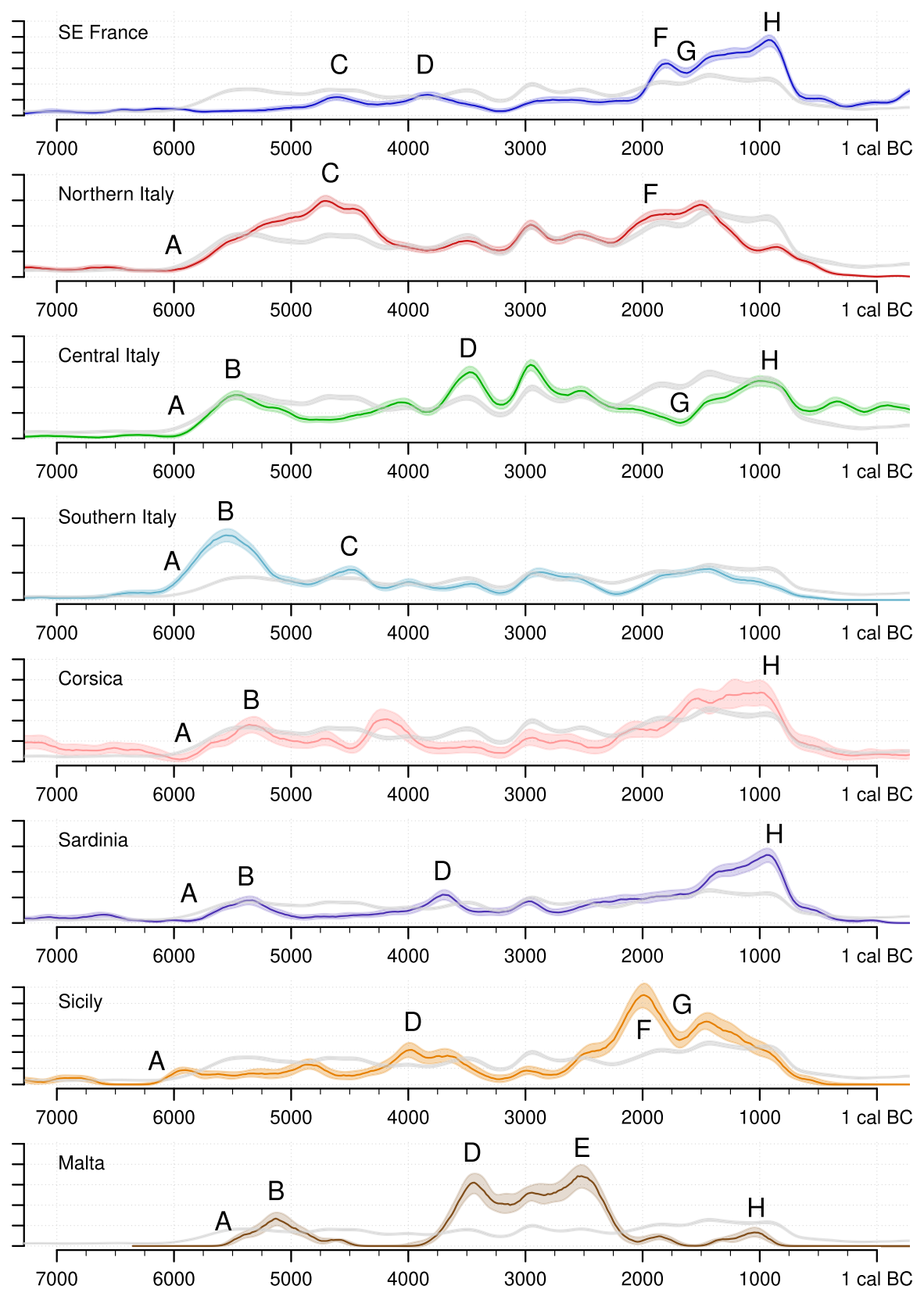

Fig. 4 KDE models (75 year bandwidth) of past human activity for each region. Letters denote the main points of discussion throughout the article. The faint grey ribbon is the KDE for the entire 4515 dates from all regions 
although weak traces of this trend can be observed across almost all of the central Mediterranean. A later collapse is then seen in the early first millennium BC, occurring earlier in the islands of Malta, Sardinia and Corsica, and slightly later in central Italy (Fig. 4, point $\mathrm{H}$ ).

It is also possible to visualize these trends as an animation by drawing a map for each calendar year and plotting the position of each radiocarbon sample as a point that is size-scaled to the posterior probability of the sample dating to that year
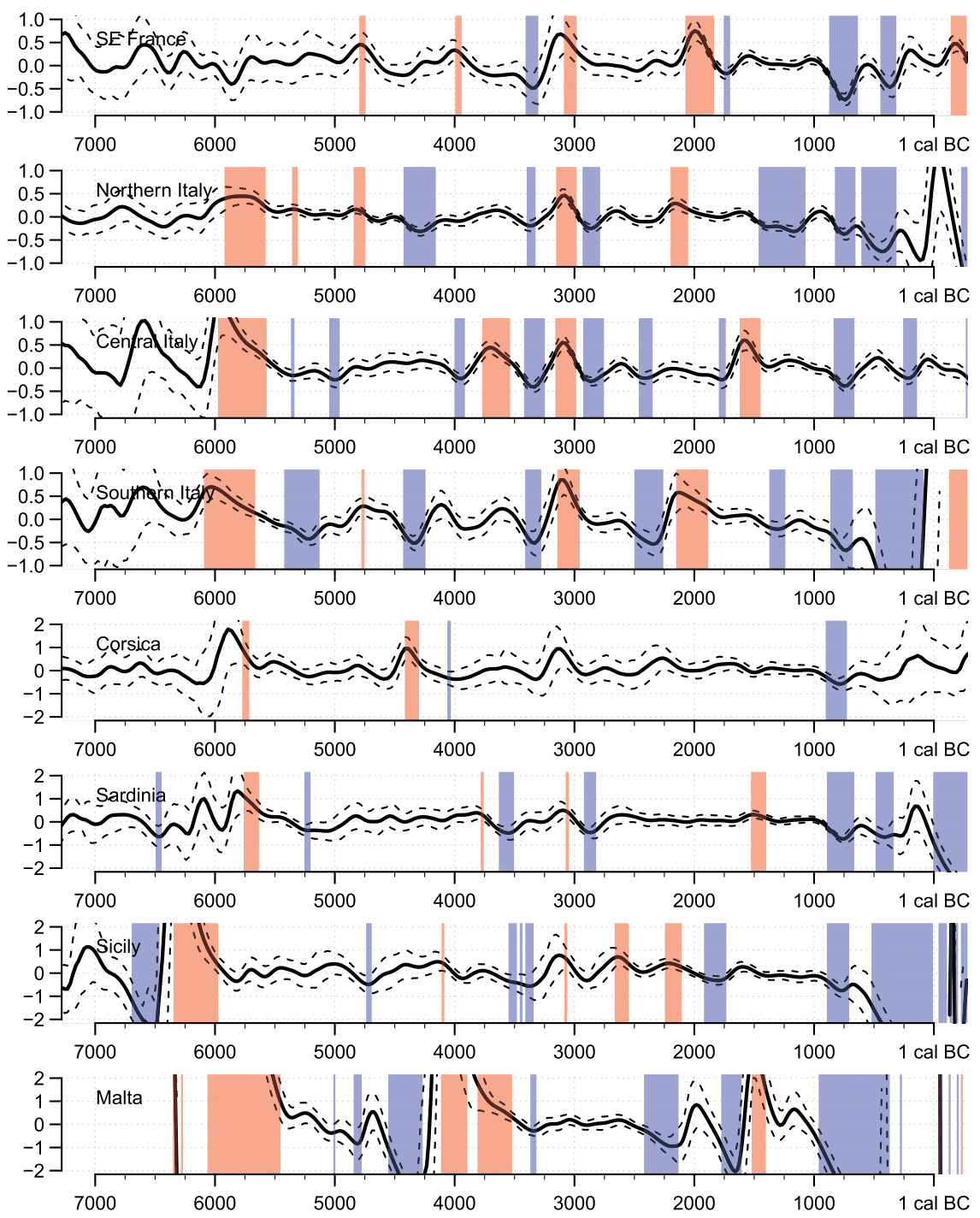

Fig. 5 Average annual growth rates (\%) for central Mediterranean (Table 4) (see Supporting Information document pp. 21-22) 
(McLaughlin et al., 2016). This analysis highlights a number of interesting spatiotemporal patterns in settlement and anthropogenic activity, especially in the Early Neolithic and Bronze Age of the Italian peninsula. In particular, the animated maps display very clearly the sparse activity throughout the region during the Mesolithic, and subsequent dense settlement in southern Italy following introduction of the Neolithic. After 6000 cal. BC, the animated maps effectively visualize the rapid maritime spread of agriculture along the Adriatic and Tyrrhenian coasts (Fig. 5) in a pattern that reflects the 'wave-of-advance' model (Ammerman \& Cavalli-Sforza, 1979) that was proposed for the introduction of agriculture into the central Mediterranean, and similar to that reported for wider Europe by Pinhasi et al. (2005). The animated maps also document the decline of intensive settlement following the initial introduction of agriculture, which is particularly noticeable on the Apulian Tavoliere in
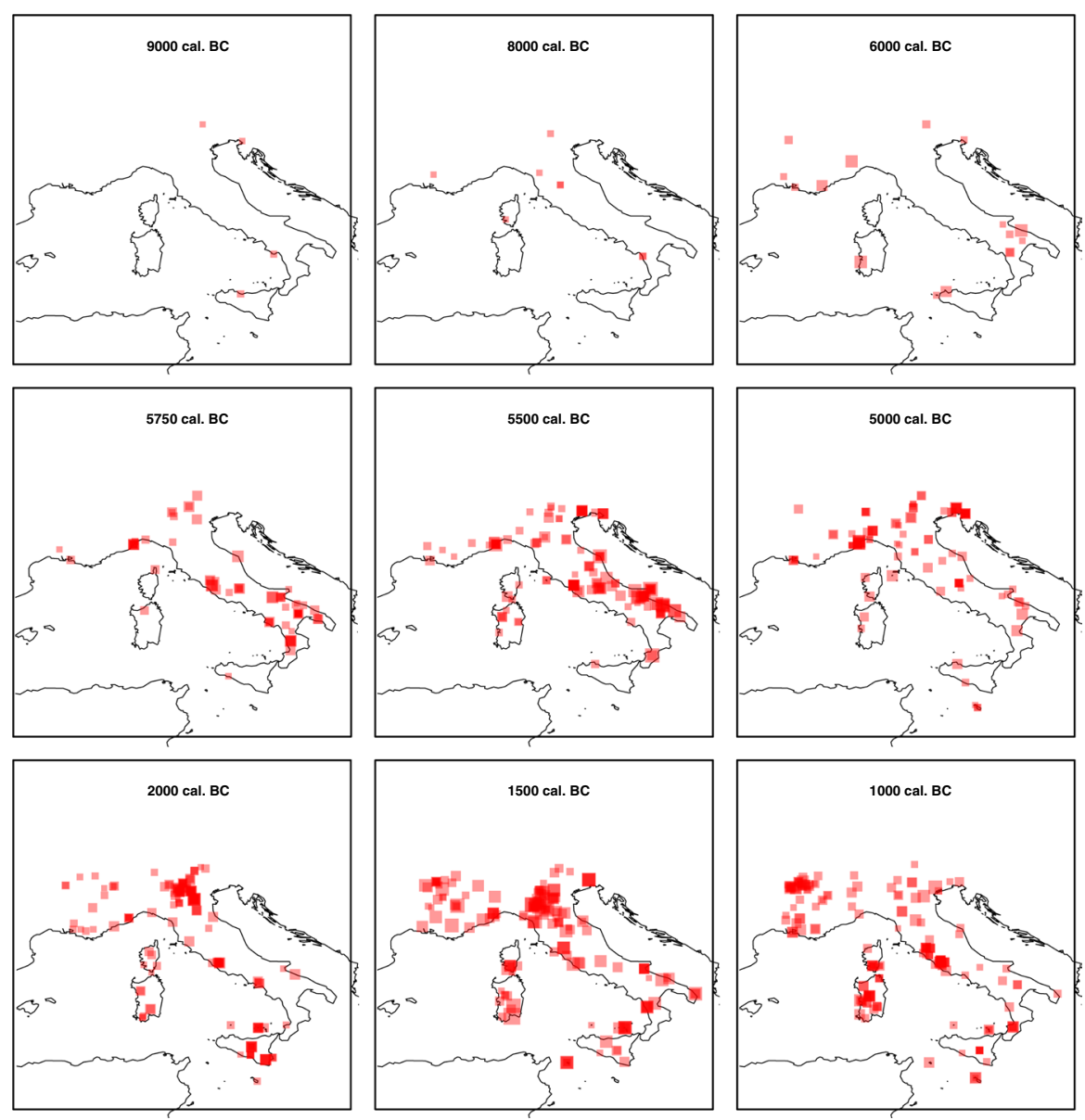

Fig. 6 Individual frames from the animated radiocarbon map included as electronic supplementary data, indicating (top) the sparse Mesolithic settlement of the region; (middle) Neolithic expansion from south to north; and (bottom) a Bronze Age shift in settlement, in the central part of the Po Plain especially 
southern Italy where activity is muted for much of the later sixth and fifth millennia BC. Changing settlement patterns over the course of the north Italian Bronze Age are also visualised, charting the marked shift in settlement from the sub-Alpine lake dwellings of the Early Bronze Age Polada culture in the late second millennium BC, to the dense settlement of the central Po Plain with the rise of the Terramare system in the mid second millennium BC (Fig. 6). As with the Neolithic however, the eventual decline of activity on the Po Plain at the end of the Bronze Age and Early Iron Age is readily apparent, and contrasts with the situation in central Italy and southeastern France, which appears more sustained.

In addition to analysing spatio-temporal trends in the archaeological record, the results highlight regional biases in coverage of radiocarbon dates (Fig. 1, Table 1). Northern and central Italy have a longer tradition of widespread and systematic application of radiocarbon dating, in contrast to the south of Italy and the islands of Sicily and Sardinia. Where northern Italy is represented by 1566 radiocarbon dates, and central Italy by 1047 radiocarbon dates, the south of Italy has just 501, representing the lowest density of radiocarbon dated sites in the central Mediterranean. Sicily and Sardinia are similarly problematic, with 233 and 263 radiocarbon dates respectively. The density of radiocarbon dates is slightly better on Corsica (185 dates), and on the Maltese Islands (155 dates) when their smaller size is taken into consideration (Table 1). In essence, these regional biases in the radiocarbon record reflect long standing scholarly traditions that divide the study of prehistory in Italy (Guidi, 2010), and have seen the application of scientific methodologies in northern-central Italy more frequently than in southern Italy and the islands (Burleigh, 1984; Malone, 2003, p. 236; Tykot, 1994). Even within regions with good coverage there is a degree of unevenness in research (Fig. 1b), with significant clusters of well-dated sites in the vicinity of Rome, on the northern fringes of the Po Valley in Veneto, in northern Tuscany, and in Liguria.

The phases of growth and decline that mark the beginning and end of defined cultural phases can also be detected in the KDE models. Most regions demonstrate marked change in activity levels during most episodes of cultural change, although the observed patterns are not universal and differ in both timing and region (Table 3). To supplement the visual comparison provided in Fig. 4, we have calculated the average growth rate for each of these events in terms of percentage change per year (Table 4) and present modern and historic population growth rates (Table 5). This is especially useful for the interpretation of the KDE models as a potential proxy for population (Haynes, 1969; Rick, 1987; Shennan et al., 2013), as annual growth rate is a well-documented statistic available for modern and historical populations. As discussed below, there are issues with interpreting radiocarbon data as a proxy for population levels, but such comparisons remain instructive and enable a further exploration of the trends we see in prehistory. 


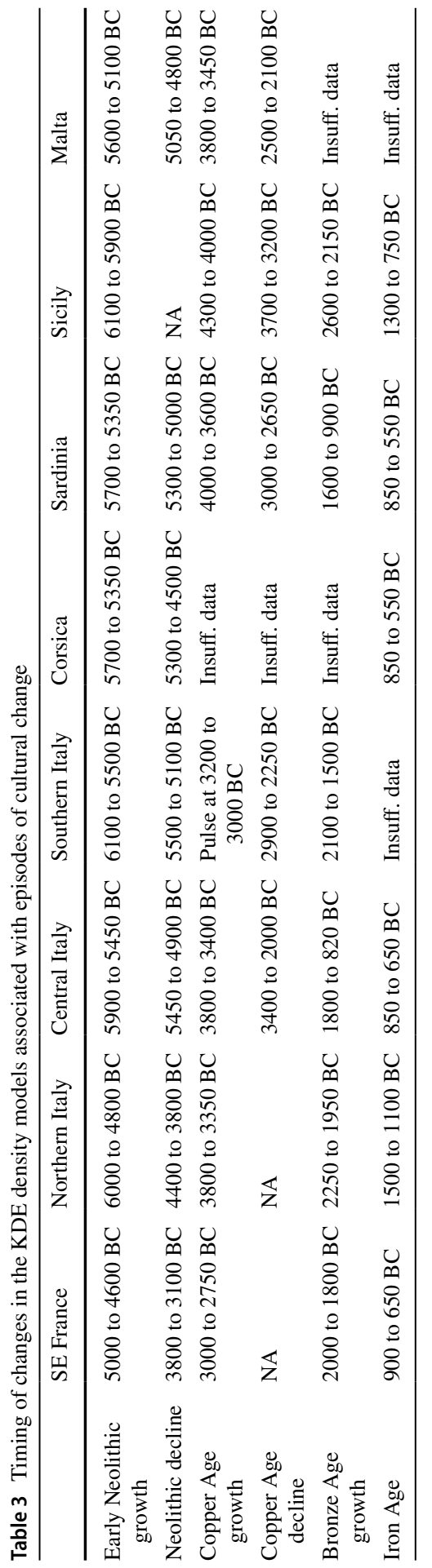




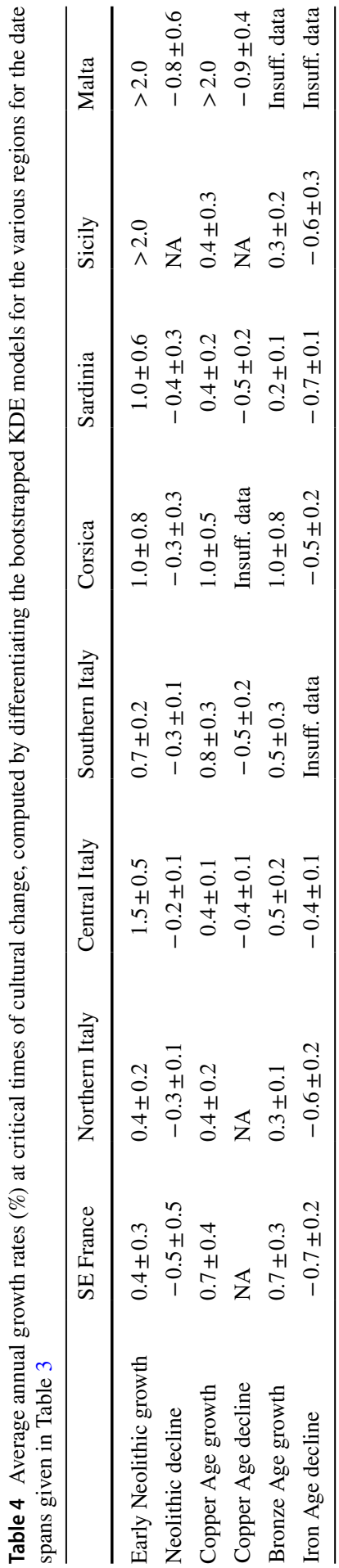


Table 5 A selection of modern and historic population growth rates, for comparison with Table 4

\begin{tabular}{lcl}
\hline Context & $\begin{array}{l}\text { Annual growth rate } \\
(\%)\end{array}$ & References \\
\hline Modern Japan & -0.23 & UN (2015) \\
Modern Italy & -0.13 & UN (2015) \\
Modern USA & 0.71 & UN (2015) \\
Modern India & 1.1 & UN (2015) \\
Modern Nigeria & 2.58 & UN (2015) \\
Global average 2015-2020 & 1.09 & UN (2015) \\
Europe, fourteenth century & -1.6 & Russell (1958) \\
USA, 1950 'baby boom' & 2.0 & US Census Bureau \\
Ireland, late nineteenth century 'potato famine' & -3.4 & Cullen (1974-5) \\
Late Mesolithic (palaeoanthropological ${ }^{\mathrm{a}}$ ) & 0.05 & Bocquet-Appel (2002) \\
Early Neolithic (palaeoanthropological ${ }^{\mathrm{a}}$ ) & 1.24 & Bocquet-Appel (2002) \\
\hline
\end{tabular}

${ }^{a}$ Derived from the proportion of immature skeletons in relatively large burial assemblages; population growth rate tends to correlate with the relative frequency of child and young adult remains in a given context

\section{Discussion}

In the following sections we discuss the main features of the KDE models in chronological order within the framework of their cultural setting. It is important, however, to acknowledge the methodological challenges that are inherent in studies of this kind. The most significant limitation of this study is that we, as archaeologists, are always constrained by the available data and by the nature of the archaeological record and the research traditions that shape it. We have attempted to gather together as many data as possible for the Italian peninsula, Sardinia, Sicily and the Maltese Islands, but acknowledge that the pressure of research has been less for Corsica and south-eastern France; similarly, our chronological focus has been the period before c. $700 \mathrm{cal}$. BC. Practical reasons have prevented us from conducting an exhaustive study of the radiocarbon evidence of the Iron Age civilizations of central Italy and the intertwined Phoenician and Greek colonization of other areas. We suspect, however, that our data constitute a robust and representative sample of the limited data available in total for the later first millennium BC. But despite the even research pressure we have applied to the Italian peninsula, some regions (the south in particular) have much less data density than others (see Table 1). Thus, a different kind of trend - the behaviour of archaeologists towards radiocarbon dating - has a powerful effect on the observed patterns, although this is extremely difficult to quantify. There may or may not be a priori biases in research interests for scholars within a given cultural context, but there are almost certain to be different research traditions, attitudes and funding priorities affecting work when different cultural contexts are compared. For this reason, it is not appropriate to compare, for example, Neolithic and Iron Age activity levels on absolute terms, although on-going work is already redressing this imbalance by engaging more with scientific dating, and comparison 
of radiocarbon evidence to other quantitative proxy measures of human activity and demography, such as surface survey (Stoddart et al., 2020, 2020a; Stoddart et al., $2020 \mathrm{~b}, 2020 \mathrm{c}$ ) and aDNA. We do, however, argue that relative changes in activity over the shorter term, or coeval comparisons of activity between neighbouring regions, remain valid because there can be no point in time when such biases suddenly take hold.

The imprecise nature of fieldwork, heterogeneous preservation of sites, and the preference for certain kinds of radiocarbon samples can, in theory, influence the results. These are essentially stochastic, or random, variables that will, according to the central limit theorem in statistics, tend to self-cancel if (and only if) a large enough dataset is under analysis. It is difficult to guess at how many dates are 'enough', and although the numbers of dates analysed here comfortably exceed the heuristic minima suggested by Williams (2012), at sub-regional levels there are very few dates for some discrete points in time or even occasional gaps in the record. We have therefore chosen an analytical scale where the KDE process produces models that evince long-term trends, sometimes operating over millennia or spanning different archaeological cultures (effectively dampening such biases), and occasionally manifesting as simultaneous peaks and troughs in different regions. Such patterns therefore simply must be independent of research and taphonomic bias. And so, although it is important to bear these various methodological limitations in mind, they do not dominate or obscure the signals we can detect. Instead these signals are being driven by events in the distant past, and we predict they will continue to improve in strength and quality as research accumulates.

We also contextualize the results of this study within the archaeology of wider Mediterranean and European regions. This too is hampered by the availability of data; if we have tended to look towards other Western European regions it is because these areas have been so well researched. Other meaningful comparisons must be left to future work, especially the archaeology of North Africa and the Balkans. We have included a preliminary comparison with North Africa in this paper, but because the spatial density of excavated and dated sites in Europe and Africa is so very different, we are simply not comparing like with like.

\section{The Mesolithic}

The KDE models suggest that there was little overall variation in the level of Mesolithic human activity in the central Mediterranean as a whole, other than a very gradual increase over time. Activity models for mainland Italian regions, Sardinia and Sicily for the period 10,000 to $6000 \mathrm{cal}$. BC are given in the Supporting Information document (pp. 6-7). These models indicate a degree of fluctuation in most regions, and occasionally significant differences from the overall picture, but given the relatively small sample sizes, these patterns could also be the product of differential preservation and other sources of bias. A weakly significant spike in activity in Sicily around $7700 \mathrm{cal}$. BC is due to a tradition of burial in caves and long-term occupation that is both archaeologically visible and well researched at a number of 
sites in the northwest of the island (D'Amore et al., 2010a, 2010b; Lo Vetro \& Martini, 2016; Lo Vetro et al., 2016).This could, on some level, reflect the underlying demography but further investigation of this phenomenon is something we leave for future work. It would be possible to extract all open-air settlement sites from the database and analyse them separately, for example, to see whether they conform to a similar trend, although reducing the size of the dataset reduces its statistical power. Similarly, decreasing levels of activity in the mid eighth millennium BC in central Italy are interesting, especially since the climate and landscape were still in a state of post-glacial flux, transitioning from the Boreal to Atlantic phases of the Holocene.

In general, however, any features and trends in the radiocarbon record of the central Mediterranean before c. $6000 \mathrm{cal}$. BC are quite weak and reflect an archaeological record that is for the most part defined by short-term occupation in rock-shelters and caves across the central-southern peninsula (Lo Vetro \& Martini, 2016; Pluciennik, 1994, 2008) and the surrounding islands (Costa et al., 2003; Lugliè, 2009a). The notable steady state of the density models for much of the Mesolithic period does not show the long-term increase in activity that would be expected under a model of stationary growth coupled with the underrepresentation of older sites due to taphonomic bias (Surovell et al., 2009). In the case of the central Mediterranean, this trend is most likely due to the predominance of cave sites, which are not subject to the same taphonomic processes as open-air sites.

\section{The Neolithic 'Boom and Bust'}

The transition to agriculture is clearly visible as a sharp increase in the gradient of the KDE density models (marked 'A' in Fig. 4), reflecting the rapid population growth and settlement density that is associated with the European Neolithic. This process did not occur simultaneously across the central Mediterranean, but once it became manifest, a similar trajectory of gradually rising then declining activity played out. In southern Italy and Sicily, the transition is first signalled in the KDE models around $6200 \mathrm{cal}$. BC, but in central Italy, southern France and the Tyrrhenian Islands it occurred later, between 5900 and $5800 \mathrm{cal}$. BC. The Neolithic reached the Maltese archipelago around $5500 \mathrm{cal}$. BC; however, activity on the islands declined around $5200 \mathrm{cal}$. BC and soon faded away entirely. New multi-proxy evidence from Malta and Gozo suggests either abandonment of the islands during this time, or a low population size and substantial landscape reorganization that left a limited trace on the island's landscape (Grima et al., 2020, p. 228; McLaughlin et al., 2020a, p. 31). Although aDNA studies have been lacking for the region until recently, current evidence from central Italy (Antonio et al., 2019), Sicily (Fernardes et al., 2020) and Sardinia (Modi et al., 2017) shows that central Mediterranean Neolithic groups conform to wider European trends by showing typical Anatolian farmer ancestry, indicating that the transition to agriculture in the region was indeed characterised by the movement of people who introduced the Neolithic way of life. The peaks in the KDE models and their timing likely reflect the demographic signature of a 'travelling wave' as suggested by Silva and Vander Linden (2017) for the European 
Neolithic, with a 'boom' in emigrants followed by a 'bust' in immigrants (see below for discussion on wider Neolithic Europe).

In most regions, the pronounced increase in Early Neolithic activity reaches a peak several centuries after the introduction of farming (identified ' $B$ ' in Fig. 4). In central and southern Italy, this occurred at $5500 \mathrm{cal}$. BC, $5300 \mathrm{cal}$. BC in Corsica and Sardinia, and $5200 \mathrm{cal}$. BC in the Maltese Islands. The staggered dates for this high point of activity in Corsica, Sardinia and Malta match the pattern of later introduction of the Neolithic to these islands and suggest that the Neolithic cultural phenomenon followed a similar trajectory in these places, but at different times, further exemplifying the 'boom and bust' characteristic of the Early Neolithic in Europe (Shennan et al., 2013). Nowhere is this more pronounced than in southern Italy, where the signal of intensification and subsequent decline is primarily driven by sites on the Tavoliere plain in Apulia.

The ditched villages of the Apulian Tavoliere have traditionally defined the Neolithic of southern Italy (Delano Smith, 1978; Pessina \& Tinè, 2018). Whilst it is clear that the ditched villages were not all occupied at once, the Tavoliere represents the densest area of settlement anywhere in Neolithic Europe (Brown, 2003), which peaked in the mid sixth millennium BC (Fiorentino et al., 2013; Parkinson \& McLaughlin, 2020), representing a major demographic event in an area with no Mesolithic presence in the preceding centuries (Perrin et al., 2021). This archaeological evidence for population increase and dense settlement activity is clearly reflected in the KDE models (Fig. 4) and animated maps (see Supplementary Information). Comparisons between historic or modern population growth rates and those derived from the radiocarbon data therefore provide a particularly useful benchmark against which the results can be interpreted (see Supporting Information, pp. 21-22). In the case of southern Italy, growth associated with the Early Neolithic started around $6200 \mathrm{cal}$. BC and increased by approximately $0.7 \pm 0.2 \%$ per year, which is less than the current global population growth rate of $1.09 \%$ and estimations for the wider European Neolithic, but similar to modern growth rates in the USA (Table 5). Our results indicate that the peak of the southern Italian Neolithic occurred between 5700 and $5450 \mathrm{cal}$. BC and signals a major demographic event, before the region entered a phase of slow decline akin to population decline rates in modern Japan (Table 5). According to Skeates (2000b), the following 5500 to 5250 cal. BC period is considered a phase of continuity among the ditched villages of the Apulian Tavoliere, with the radiocarbon evidence suggesting a general backdrop of declining activity levels and settlement intensity. In central Italy, an Early Neolithic peak occurred at $5500 \mathrm{cal}$. BC, and although this was followed by a reduction in activity, the decline was much more gradual than it was in the south.

The eventual abandonment of the Tavoliere, so visibly apparent in the KDE models for southern Italy and animated maps, has been hypothesized to be the result of possible land exhaustion and overpopulation that led to settlement expansion into nearby valleys (Malone, 2003, pp. 252-253; Whitehouse, 2013). Fiorentino et al. (2013) identified a wet period that occurred on the Tavoliere between 6200 and 5500 cal. BC, which was followed by a dry period, coinciding directly with the growth and subsequent decline observed in the KDE analysis presented here. This may suggest that favourable climatic factors played a major role in shaping the 

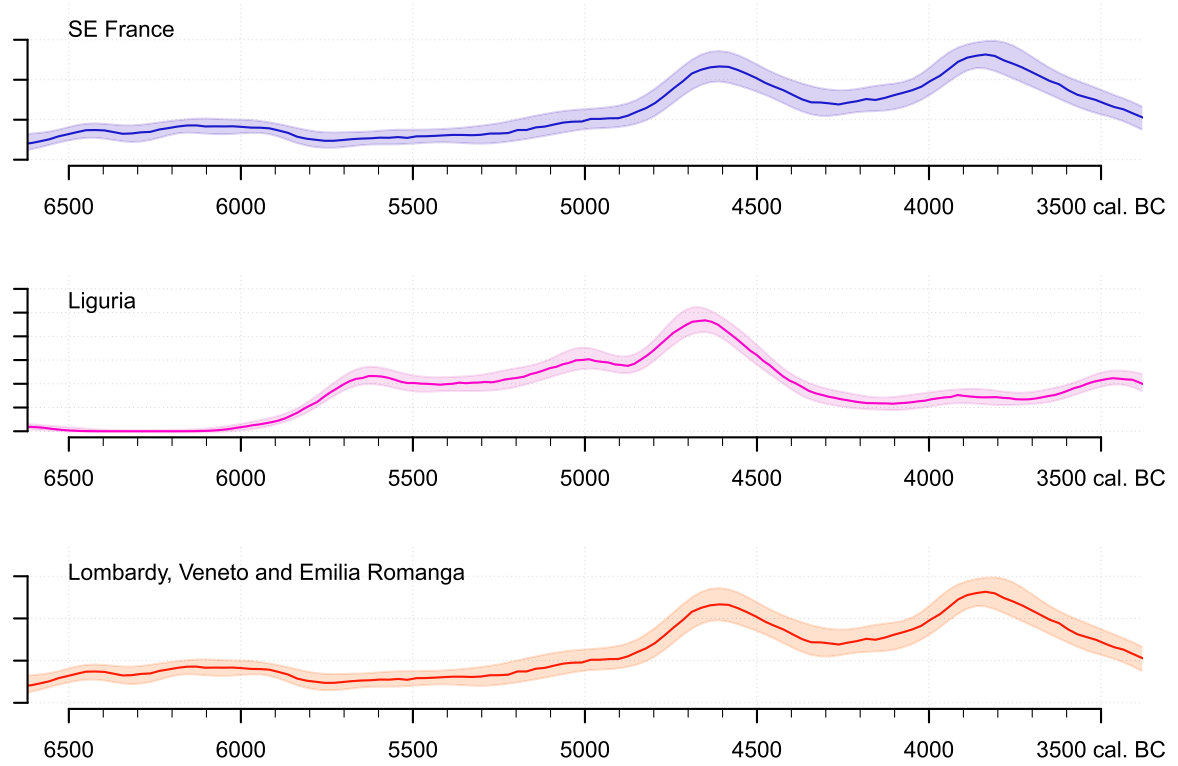

Fig. 7 Regional differences between the Neolithic in southeast France, northwest Italy (Liguria) and regions in central-northeast Italy (Lombardy, Veneto and Emilia-Romagna) (see Supporting Information document pp. 8-9)

southern Italian Neolithic, and that a mixture of overpopulation, land exhaustion and climate probably triggered a decline in human activity and settlement in the area. This observation is corroborated by a second spike in the KDE model for southern Italy during the later Neolithic at around 4500 cal. BC (Fig. 4, point C), which corresponds with a second brief wet period recorded on the Tavoliere by Fiorentino et al. (2013).

In northern Italy, our results show how the transition to agriculture played out in a markedly different way, characterised by an initial period of relatively rapid growth which slowed at $5500 \mathrm{cal}$. BC before finally peaking around $4800 \mathrm{cal}$. BC. However, when viewed at a sub-regional level, the results illustrate the stark differences between north-western and north-eastern Italy during the Early Neolithic (Fig. 7). The early arrival of the Neolithic in the north-western region of Liguria is apparent in Fig. 7 (Binder et al., 2017; Maggi et al., 2020) and contrasts with the much more muted introduction of agriculture towards the north-east on the Po Plain. These regional differences have long been acknowledged in the cultural setting of the Early Neolithic of northern Italy, which is characterized by a variety of regional ceramic traditions (Malone, 2003, p. 251) including the Ligurian impressed wareswhich display a visible influence from southern Italy - and, to the north-east, the Isolino, Fiorano, Vhò, Gaban and Fagnigola groups on the Po and in the Alpine valleys, which so clearly stand apart from the broader central-western Mediterranean context. Rather than directly relating to the broader Impressed-Cardial complex that characterises the Early Neolithic of the central-western Mediterranean, the ceramic traditions of north-eastern Italy have been argued to be influenced by Adriatic or 
central Italian traditions (Biagi et al., 2020, pp. 194-195; Pearce, 2013, p. 204). The evidence for continued Mesolithic presence in parts of northern and central Italy has also been cited as a factor in how the Neolithic played out in this part of Italy and its timing (for discussions see Binder, 2000; Pearce, 2013, pp. 206-207), but overlaps between Mesolithic groups and Neolithic groups now seem less likely (MartínezGrau et al., 2020). In terms of settlement, the record for the Early Neolithic of the Po Plain area is scant, in strong contrast to the south, with much of the evidence stemming from the so-called fondi di capanna, large storage pits previously considered to be hut foundations (Biagi et al., 2020), and the results of the KDE and animated map seem to illustrate this general picture. There are therefore still significant issues pertaining to the mechanisms behind the introduction and subsequent trajectory of the Neolithic into the central/north-eastern areas of Italy, the timing of which was perhaps additionally influenced by climatic factors and differences in physical

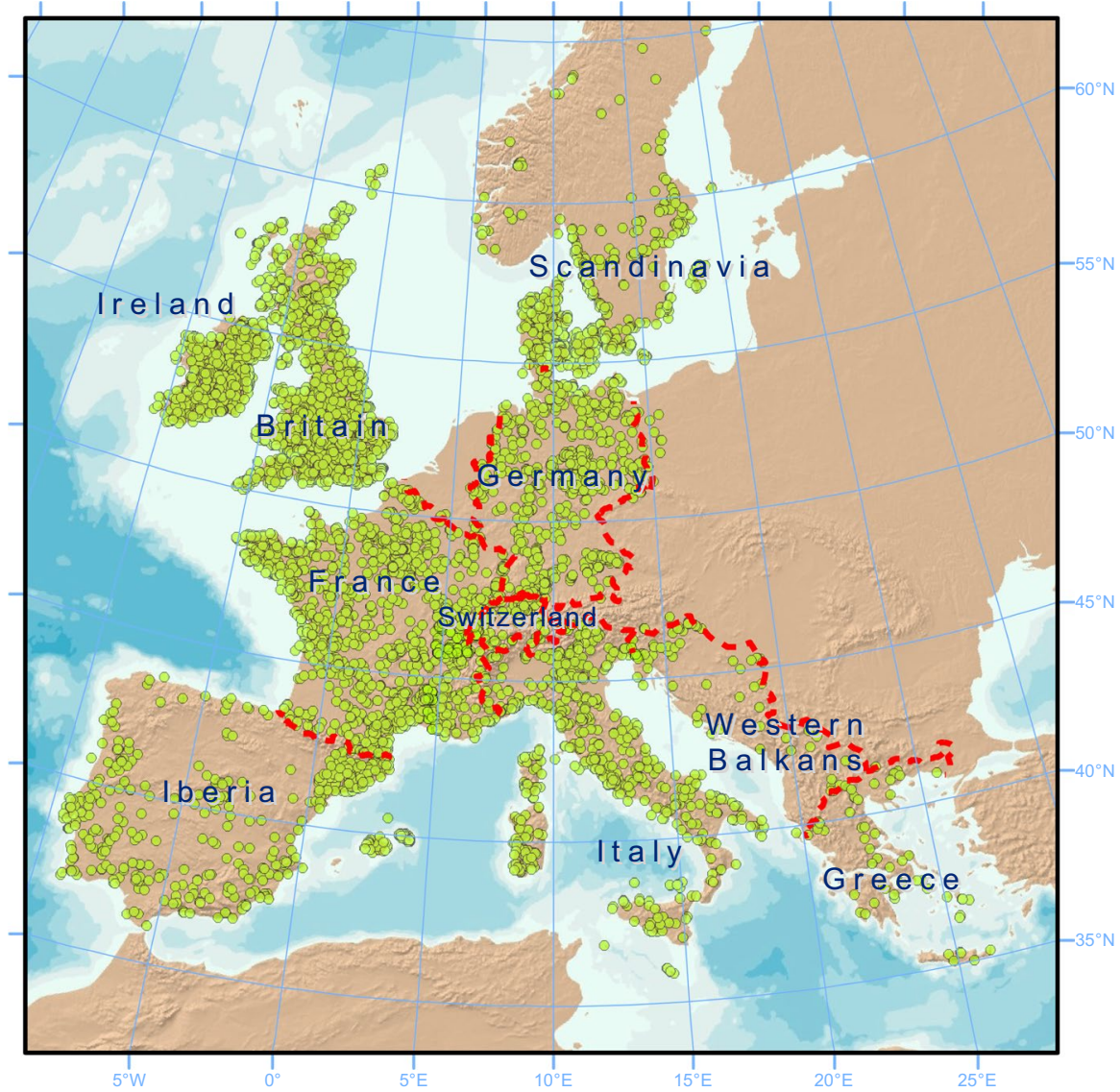

Fig. 8 Locations of comparative 14C samples analysed in this paper, including those drawn from Bevan et al.'s (2017) data, and the BANADORA, RADON and RADON-B databases. These data are used in Figs. 9 and 12 in a comparison with the central Mediterranean 

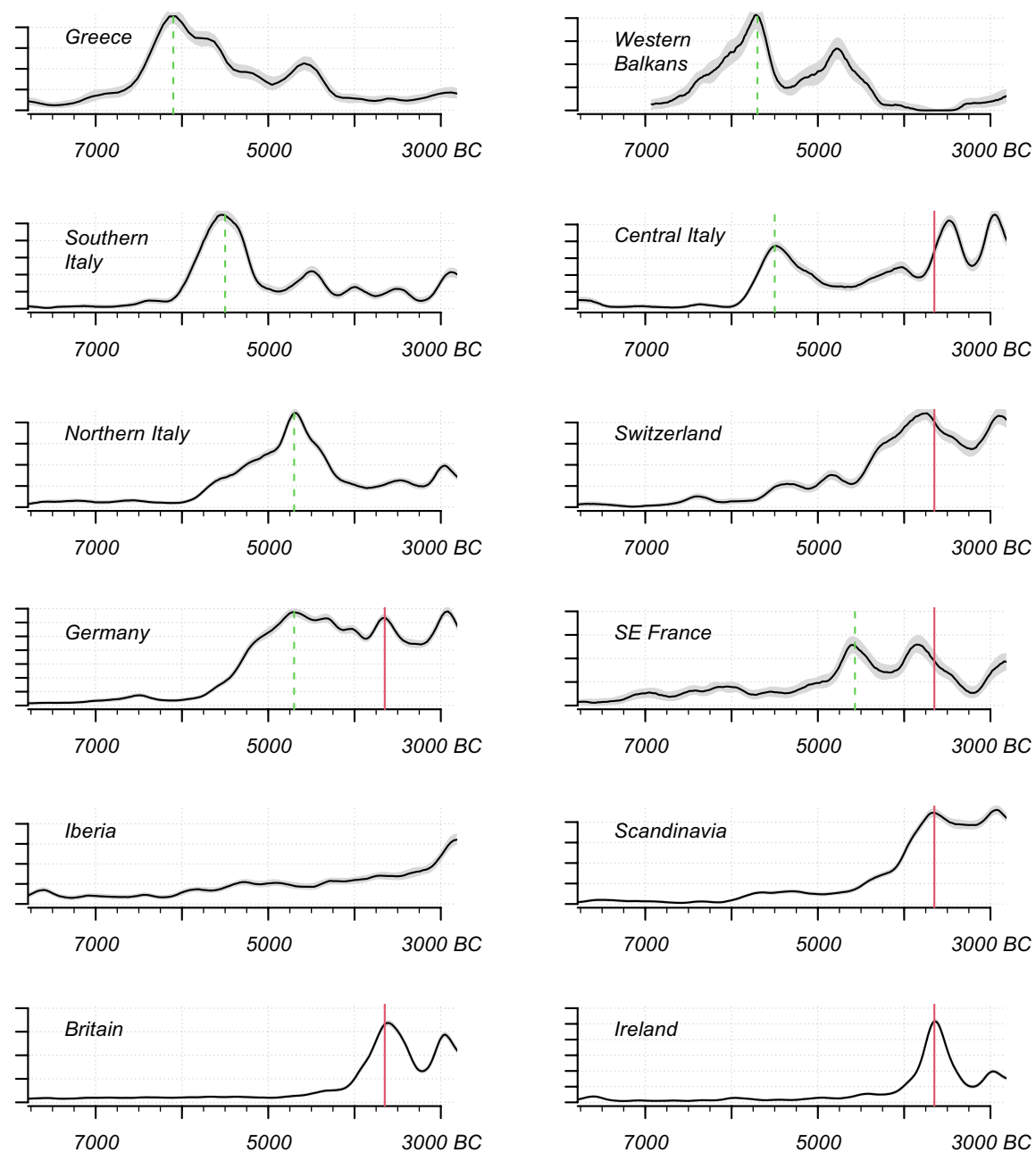

Fig. 9 Early Neolithic KDE prehistoric activity models (75-year bandwidth) for peninsular Italy and other European regions, with the Early Neolithic 'boom' highlighted with a dashed line and 3700 BC highlighted with a solid line. Data sources: Italy, this paper; Britain and Ireland, Bevan et al. (2017); France, the BANADORA database (http://www.arar.mom.fr/banadora/); and other regions, the RADON database (http://radon.ufg.uni-kiel.de)

landscape. Ultimately, these can only be resolved by future research and targeted radiocarbon dating in the Adriatic area, as well as further consideration of the eastern shore of the Adriatic, which is vital to this story, and is currently the topic of further research by the authors.

The availability of databases of radiocarbon dates for neighbouring regions (RADON and BANADORA) also allows for comparisons to be drawn between the central Mediterranean and other European regions (Figs. 8 and 9). Although there are obvious differences in timing, the comparison demonstrates that southern Italian 
settlement patterns in the Early Neolithic were very similar to those on the opposite side of the Adriatic. Likewise, there are commonalities between subsets of these European regions throughout time. For example, the northern Italian apogee of 4500 cal. BC was also manifested less prominently, but still significantly in southern Italy (Fig. 4, point 'C'), and is also apparent in the records from south-eastern France, Iberia and Germany. The German case was associated with the final phases of LBK culture and the conclusion of 600 years of growth. In northern Italy, the increase at $4800 \mathrm{cal}$. BC is related to the widespread distribution of Middle Neolithic VBQ/Square-Mouthed Pottery sites across the region (Mottes et al., 2009; Visentini, 2006), which are well documented in the Ligurian caves, but also by a density of sites on the central Po Plain. Later, a widespread spike in activity early in the fourth millennium BC can be detected in central Italy, Switzerland, Germany, France, Scandinavia, Britain and Ireland. There are differences in the timing of this spike, which again allow us to visualise the 'boom and bust' and 'travelling wave' characteristics of the European Neolithic at the continental level (Shennan et al., 2013; Silva \& Vander Linden, 2017). That said, almost everywhere saw a downturn in the mid fourth millennium BC.

Comparisons with North Africa (north of $13^{\circ} \mathrm{N}$ ) can be made using the archaeological radiocarbon dataset published by Manning and Timpson (2014). This dataset captures the continental-scale demographic transformations brought about by the start and end of the African Humid Period (8500 to 3500 cal. BC) and, importantly, a temporary decline in activity spanning 5600 and 4700 cal. BC. In addition, the more detailed database published by Lucarini et al. (2020) of African sites in Mediterranean regions can be used to compare regional European patterns with those in Africa (Fig. 10). Whilst the sparse nature of the African data precludes a detailed spatial analysis, the overall signals of activity from North Africa and the European central Mediterranean share many characteristics. In particular, the Early Neolithic lull at $5100 \mathrm{cal}$. BC is common to both continents, although the fluctuations in activity that followed over the subsequent millennia were rather different. As discussed by Manning and Timpson (2014), such trends in the combination of archaeological data over a huge area suggest that human activity in prehistory was strongly influenced by climatic forces, even though the human response to these environmental challenges was different in each region and time period.

The mid fourth millennium BC is associated with the start of the Copper Age in the central Mediterranean, which brought with it marked regional diversity in the archaeological record, particularly in the island contexts of Sicily, Sardinia and the Maltese archipelago — as illustrated in the density models (Fig. 4, point 'D'). Peninsular Italian Copper Age groups show genetic continuity from the Neolithic, in contrast to later Bronze Age groups (D’Amore et al., 2010a, 2010b; Saupe et al., 2021), indicating apparent population stability during the period. In central Italy, a gradual increase in activity occurred from $3800 \mathrm{cal}$. BC, peaking at $3500 \mathrm{cal}$. BC. Settlement evidence for the central Italian Copper Age is fairly patchy, although the occurrence of densely clustered cemeteries in areas lacking definitive settlement evidence (e.g. the Tuscany-Latium border), as well as a growing body of stable settlement evidence in areas of Marche and central Latium (Anzidei \& Carboni, 2020; Cazzella, \& Moscoloni, 1999; Manfredini, 2014) paints a picture of population increase 

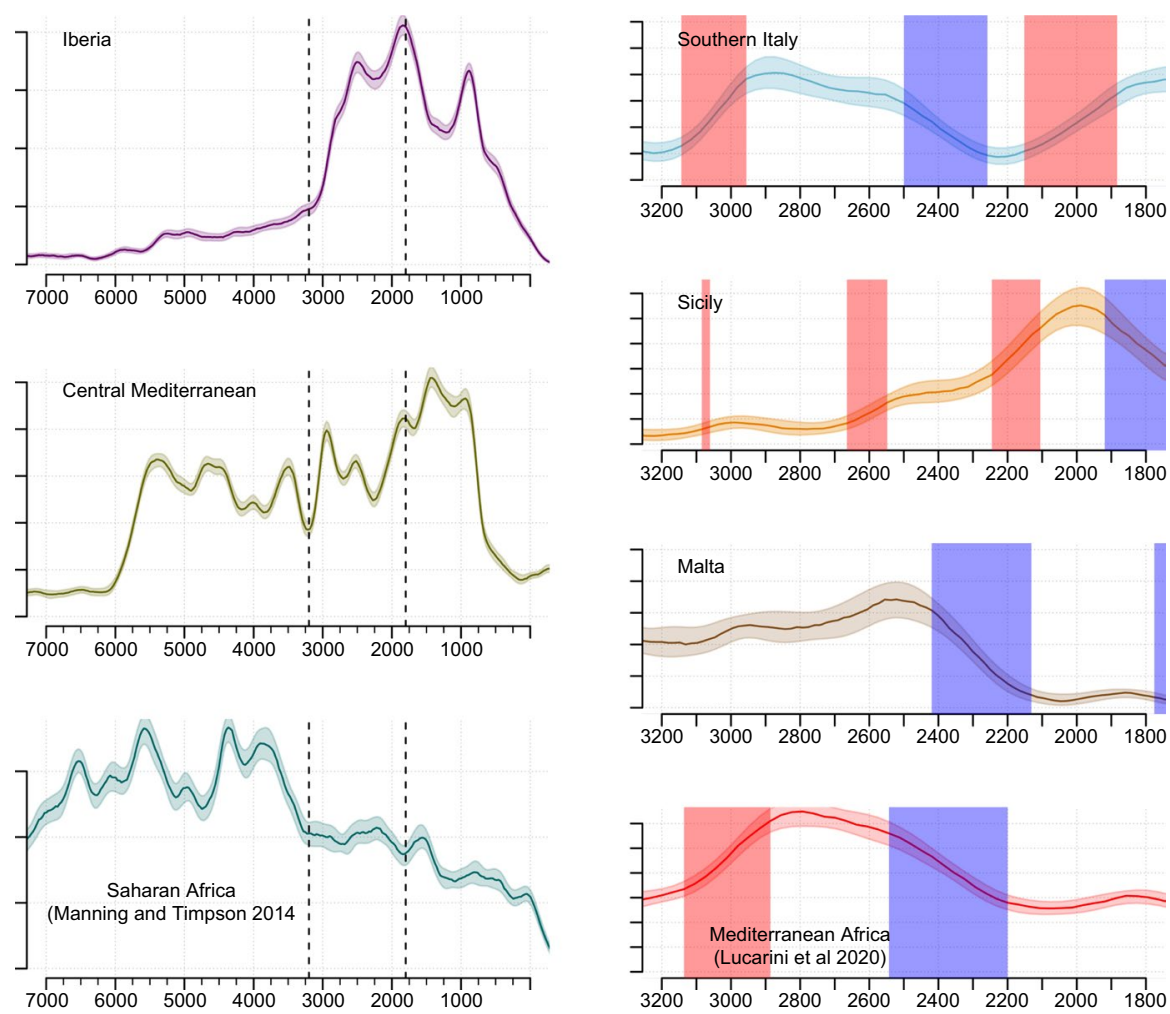

Fig. 10 KDEs for Iberia (RADON database) and central Mediterranean Europe (this paper) and North Africa (Lucarini et al., 2020; Manning \& Timpson, 2014) for 7000 BC onwards (left panels) and a selection of results from the Copper Age and Early Bronze Age (right panels), with periods of significant positive or negative growth shaded

during the earlier Copper Age in this region of Italy, and seems to be reflected in the KDE model. These results are similar to those reported for the fourth millennium BC by Palmisano et al., $(2017,2018)$; however, in discussing their results they incorrectly state the beginning of the Copper Age in central Italy as 3000 cal. BC, when it is widely acknowledged as starting at approximately 3600 cal. BC (Dolfini, 2010, 2013; Cocchi Genick, 2013). Thus, the discussion by Palmisano et al. (2017, 2018) of trends across the fourth millennium BC is not framed within the appropriate cultural context, underscoring the importance of acknowledging local chronologies within larger syntheses so that they remain relevant to the traditions of research in the region.

In contrast to central Italy, activity in southern Italy remained low, reflecting the scarce evidence for Copper Age settlement in regions such as Apulia, and only a slight rise can be observed for northern Italy. In Sicily, a significant upturn in activity at $4000 \mathrm{cal}$. BC corresponds to the beginning of the 'proto-Eneolithic', where an increase in the number of archaeological sites is associated with the San Cono-Piano 
Notaro and Conca d'Oro cultures. Unlike on the mainland, in Sicily the peak steadily decreased throughout the first half of the fourth millennium BC (Fig. 4, point 'D'). By this time, activity in the Maltese Islands underwent a significant increase, with growth rates above $2 \%$ per annum, from 3800 cal. BC until a peak at 3400 cal. BC. This is associated with the Żebbug and Ggantija phases, which saw the development of megalithic architecture, which proliferated throughout the 'Temple Period' then briefly declined during the transition to the third millennium BC. The close parallels between Sicilian San Cono-Piano Notaro and Maltese Żebbug material culture (Leighton, 1999, p. 93; Speciale, 2011), and evidence for direct exchange of material culture (Barone et al., 2010), clearly demonstrate contact between the two islands at a time of fluctuating activity levels. While we should be cautious about stretching our interpretations of the data too far, the sustained phase of growth in the activity model for the Maltese Islands could be interpreted as a response to demographic pressures in Sicily, and may reaffirm that the unique 'Temple Period' cultures of Malta and Gozo had an antecedent in Sicily around $4000 \mathrm{cal}$. BC.

In Sardinia and southeast France, significant peaks occurred early in the fourth millennium BC. These points represent relatively short-term flares of activity and only in northern Italy does a modest mid-fourth-millennium BC increase appear more sustained, as it was during the Neolithic. The fourth millennium BC in the central Mediterranean shows asynchronous developments in anthropogenic activity, most of which occur in what are Late/Final Neolithic cultural contexts (Sardinia, Sicily, SE France, Maltese Islands) rather than in the Copper Age as in central Italy. This not only highlights the gradual nature of the transformations from the Neolithic and Copper Age in the central Mediterranean, but also suggests that the driving features of these trends were probably the social and economic developments that characterize the fourth millennium BC, rather than the impact of technological developments related to metal working and resource exploitation.

\section{The Apogee of the Temple Period on the Maltese Islands (Fig. 4, Point E)}

Whilst the density models suggest lower but stable levels of human activity across much of the central Mediterranean in the third millennium BC, there is a distinctive apogee in the KDE models at $2500 \mathrm{cal}$. BC in the Maltese Islands (Fig. 4, point 'E'; see also Fig. 10). The mid-third-millennium BC peak followed a downturn around 3000 cal. BC, and possibly reflects a period of population recovery and eventual flourishing of ritual activity on the islands after an apparently difficult few centuries. Current evidence indicates that the soil cover of the Maltese Islands became progressively denuded over the course of the Temple Period, and that soil amendment processes were undertaken possibly as early as the early-mid third millennium BC (French et al., 2018). This may suggest that land management practices played a part in averting total collapse of the Temple Period around $3000 \mathrm{cal}$. BC, and instead triggered a rebound. It has long been suggested that agriculture intensified towards the end of the Temple Period, during the concluding Tarxien phase, under a more controlled system for which megalithic sites formed a focus, and possibly in response to increasing economic and environmental instability (Stoddart et al., 
1993; Trump, 1980). Recent work has significantly added to this picture by arguing that the Maltese megalithic sites played an important economic role in facilitating the display, consumption and organisation of resources within the restricted environment of the islands (Barratt et al., 2020; Malone et al., 2020b, p. 477). Archaeological evidence from excavated sites shows evidence for increased ritual activity at 2500 cal. BC (McLaughlin et al., 2020a; Thompson et al., 2020), and whilst the phasing of the Maltese temples remains difficult (Grima, 2008), it has been suggested that the present form of most megalithic sites on the islands reflects a final episode of restructuring and ritual elaboration at a crucial point towards the end of the Temple Period (Malone, 2007). Episodes of crisis management have been noted in monument-building societies elsewhere, as in the Sardinian Bronze Age (Ialongo, 2018), although in the case of the Maltese Islands the recovery was short lived. Activity on the islands appears to have tipped into decline after 2500 cal. BC, during a period that is associated with declining population health, the eventual end of monument building and significant environmental change driven by increasing aridity (French et al., 2020, p. 320).

This localized trend embodies the singularity of the Maltese archipelago's archaeological course during the fourth and third millennia BC. Elsewhere in the central Mediterranean, it is only on neighbouring Sicily that a significant increase in activity is initiated at around 2800 cal. BC (Fig. 4, point 'F'; Fig. 10), as part of a gradual intensification leading into the Early Bronze Age (see following section for discussion). Whilst the gradual growth in Sicily seems somewhat concurrent with the decline on the Maltese Islands at $2500 \mathrm{cal}$. BC, the growth in Sicily is initiated some three hundred years earlier. It has been proposed that the end of the Maltese Temple Period prompted an exodus out of the islands into neighbouring areas, most likely Sicily (Bonanno, 1993), and archaeological evidence points towards increasing ties between the two regions in the later third millennium BC (Procelli, 1996; Leighton, 1999, p. 137; Tanasi, 2014). The results of the KDE, therefore, do not appear to support this directly, and recent research has instead shown that the end of the Maltese Temple Period was defined by a gradual transition into the Early Bronze Age with a transitional 'Thermi' ware phase in the mid-late third millennium BC (McLaughlin et al., 2020a, p. 33).

\section{Early Bronze Age Intensification and Middle Bronze Age Dynamics (Fig. 4, Points F and G)}

The decline in activity levels at the close of the third millennium BC in the Maltese Islands is also mirrored by the KDE models from southern Italy and Mediterranean Africa (Fig. 10). As the Early Bronze Age emerged, only in southeast France, northern Italy, and Sicily was a significant increase in activity observed (Fig. 4, point ' $F$ '). Northern Italy enjoyed stability during the first half of the second millennium BC, in contrast to the adjacent areas of southeast France and central Italy, where a pronounced drop in activity appears to have occurred (Fig. 4, point ' $G$ '). In Sicily, this pattern is also apparent, as the end of the Copper Age and Early Bronze Age signalled a 500-year period of sustained growth 
that reached its peak at $2000 \mathrm{cal}$ BC (Fig. 4, point ' $F$ '), followed by a significant decrease in activity around $1700 \mathrm{cal}$. BC in the lead-up to the Middle Bronze Age (Fig. 4, point ' $G$ ').

The Early Bronze Age of Sicily is traditionally recognized as a period of considerable settlement expansion and population increase (Malone et al., 1994a, 1994b), but Leighton (2005) has argued that a lack of landscape survey data for Sicily may mean that this narrative has been historically overemphasized (Leighton, 2005). The density models seem to support the former interpretation, although understanding the decline around 1700 cal. BC is more problematic. Leighton (2005) further suggested that contraction and discontinuity in settlement patterns occurred between the Early and Middle Bronze Ages in Sicily, whilst the Aeolian Islands show similar contraction of settlement into nucleated villages located on naturally defended higher ground as the Early Bronze Age progressed (Alberti, 2013a; Bietti Sestieri, 2013b). In central Sicily, site counts also suggest a sharp increase in Late Copper Age and Early Bronze Age settlement, followed by a considerable drop in the Middle Bronze Age (Giannitrapani, 2016), mirroring the trends in our density model. The results of the KDE analysis (Fig. 4, point ' $G$ ') may therefore corroborate the evidence for settlement nucleation and a punctuated transition between the Sicilian Early and Middle Bronze Ages_-although the decline observed at $1700 \mathrm{cal}$. BC does appear to have been a synchronous phenomenon across the wider central Mediterranean. Interestingly, the dynamics of human activity in Sicily, as suggested by the $\mathrm{KDE}$ and observed in the archaeological record, also appear to correspond loosely with episodes of demographic change on the island, namely the arrival of Steppe ancestry by $2200 \mathrm{cal}$ BC and possible Aegean ancestry between 1800 and 1500 cal. BC (Fernandes et al., 2020).

The density models and animated map are particularly illustrative of events in Early and Middle Bronze Age northern Italy, where the radiocarbon dates derive largely from Polada pile dwellings along the southern fringe of the Alps, and the Terramare system on the central Po Plain. The rapid demographic development and settlement density that is associated with the Polada culture (Barfield, 1994a; Nicolis, 2013) is clearly reflected in the KDE models (Fig. 4, point 'F') and the subsequent rise of the Terramare system sees further development of this trend. The demographic increase associated with the Terramare was accompanied by a general increase in site size over time (Cardarelli, 2009; Vanzetti, 2013), with the largest sites estimated to have accommodated up to a thousand people (Nicolis, 2013), and with population estimates for the entire system as high as 150,000 people (Cardarelli, 2018). With the exception of an insignificant decrease around $1700 \mathrm{cal}$. BC, the density models show consistent activity levels between the Early and Middle Bronze Age in northern Italy. This trend is unsurprising, given that both periods are associated with increased population levels, with the major change across the Early Bronze Age-Middle Bronze Age transition being a marked spatial shift in settlement from the southern fringe of the Alps to the Po Plain. The shift towards extremely high settlement density on the Po Plain and continuing demographic expansion is therefore better visualized in the animated radiocarbon maps from 2200 to 1450 cal. BC (Fig. 5; see supplementary data). The consistency in the KDE models does, however, indicate some degree of continuity between the two periods, and may in 
some way contribute to the remaining debate as to whether the Terramare developed out of the earlier Polada pile dwellings (Nicolis, 2013; Vanzetti, 2013).

At the end of the Terramare, the gradual decline documented in the density models spanning approximately 1500 and 1100 cal. BC (approximately $0.9 \%$ per annum) does not reflect the collapse that is traditionally associated with the north Italian Recent Bronze Age between 1350 and 1150 BC (Cardarelli, 2009; Vanzetti, 2013). Whilst Terramare sites suffered decline in the southern Po Plain towards the end of the second millennium BC, several well-studied larger villages in the Grandi Valli Veronesi north of the Po River continued to thrive into the Final Bronze Age (Cupitò et al., 2015), and were engaged in broader continental and eastern Mediterranean trade networks as well as a high degree of intergroup mobility between settlements (Cavazutti et al., 2019). However, it is still a matter of debate whether the sites were suddenly abandoned at exactly the same time throughout the territory or whether the abandonment occurred over a prolonged period of crisis (Cardarelli, 2009, p. 485). Whilst the KDE models reflect the general timing of the Terramare collapse, the precise dynamics of the Recent and Final Bronze Age in northern Italy are perhaps better visualised in the animated maps where the activity associated with the Grandi Valli Veronesi sites is apparent (see supplementary data).

The results of the KDE models from $1100 \mathrm{cal}$. BC, following the decline of the Terramare, reflect the reduced levels of human activity on the Po Plain during the Final Bronze Age and Early Iron Age (Barfield, 1994a), in comparison with neighbouring areas of southeast France and central Italy which saw sustained and gradual growth (Fig. 4) (cf. Mathers and Stoddart, 1994 who registered these unaligned cycles of expansion and decline). The extent to which this trend may relate to demographic shifts is difficult to assess and touches upon a controversial theme that dominated research on the Terramare until the mid twentieth century (see Pearce, 1998). However, this period in southeast France is associated with north Italian influences on material culture (Mordant, 2013), also seen to a lesser extent in central Italy (Cardarelli, 2009; Manfredini et al., 2009). By contrast, southern Italy remained very quiet at this time, as reflected in the archaeological record (Bietti Sestieri, 2013a), but the impact of negative research bias must be emphasized, as the south of the Italian peninsula has on the whole fewer dated sites to represent later periods.

\section{Early First Millennium BC Collapse (Fig. 4, Point H)}

A significant and rather sudden decline in the KDE models occurs in central Italy, Corsica and Sardinia in the early first millennium BC (Fig. 4, point ' $H$ '). This is most pronounced in the record from Sardinia associated with the end of the Nuragic civilization. From 1500 cal. BC activity on the island gradually increased year-onyear, reaching its most intense level at a point between 980 and $820 \mathrm{BC}$, which was apparently succeeded by sudden collapse. Using simulation and back-calibration we have modelled different scenarios for this process (Fig. 9, see Supporting Information pp. 18-20); the models most consistent with the data feature an abrupt drop in activity around 800 cal. BC (Fig. 9, simulations 1 and 2). Although it is important to acknowledge that this approach does not 'prove' the mathematical correctness of the 
model, it nonetheless provides a plausible explanation for patterning of the radiocarbon data. The density models suggest that there was between a four- and 13-fold reduction in activity in Sardinia over a 150-175 year period, beginning between 980 and $820 \mathrm{BC}$. Whilst these results could reflect an edge effect as a result of negative research biases, clear regional differences across Sardinia during the Final Bronze Age (Lo Schiavo, 2013), and the apparent weakening and restructuring of the political structure of Nuragic civilization in the face of increasing foreign contact (Blake, 2015), are important factors that led to the decline of the nuraghi at the onset of the Iron Age. The first millennium BC in Sardinia also appears to signal a period of significant genomic transformation on the island (Marcus et al., 2020), with postNuragic period Iron Age individuals showing less evidence for pre-Bronze Age indigenous ancestry (Fernandes et al., 2020), altering the previously-held view that Sardinia was isolated from substantial genetic admixture and population migrations since the Neolithic (see Chang et al., 2018 for overview).

The same period in central Italy saw a similar, but less dramatic, reduction, which by virtue of a better-resolved record, can be more precisely dated to between 900 and $820 \mathrm{BC}$. In central Italy, the decline was a two- to three-fold reduction over the course of about 175 years. Significantly, in central Italy the reduction in activity recovered and by 600 cal. BC activity was once again intensifying, now associated with the emergence of city states (Barker \& Stoddart, 1994). It will be important to concentrate research and future dating projects on this period between 900 and $600 \mathrm{BC}$, in conjunction with use of Bayesian statistics on relevant stratigraphies at the beginning of the Hallstatt plateau to investigate this significant phase of central Italian state formation and whether nucleation was accompanied by demographic pressures. Some important stratigraphies in the powerful places of Etruria cross this boundary (e.g. Tarquinia) and could be employed to test alternative interpretations and the validity of the demographic changes. In Sardinia, however, the recovery never came following the endemic collapse of 900 cal. BC (Fig. 4, point H), after which settlement and burial activity declined (Tronchetti, 2015), with most Nuragic sites abandoned and the nuraghe itself being reduced to an almost totemic symbol of Sardinian identity (Blake, 1997; Minoja and Usai, 2015).

The question of whether this decline was sudden or gradual is therefore an important one. Although radiocarbon data are not well suited to reflecting rapid change due to the uncertainties involved, simulation modelling can be used to build hypothetical models of activity, and via a stochastic 'Monte Carlo' process, calculate how this pattern would be reflected in archaeological radiocarbon data. Such exercises also exclude the possibility that plateaux in the calibration curve influence the kernel density estimates. Testing three alternative scenarios in this way (Fig. 11), we can see that the Nuragic decline more closely corresponds to a sudden and drastic reduction in activity, rather than a gradual one.

It is possible to draw further parallels between the significant trends of central Italy, Sardinia and Corsica with events occurring elsewhere, using data from the RADON-B database. The downturn of 900-820 BC seen in the radiocarbon record from central Italy is mirrored, somewhat surprisingly, by events much further north in Scandinavia and Ireland (Fig. 12). In all three cases the density model plummets to lower values that are then sustained from c. $700 \mathrm{cal}$. BC. The pattern is also weakly 


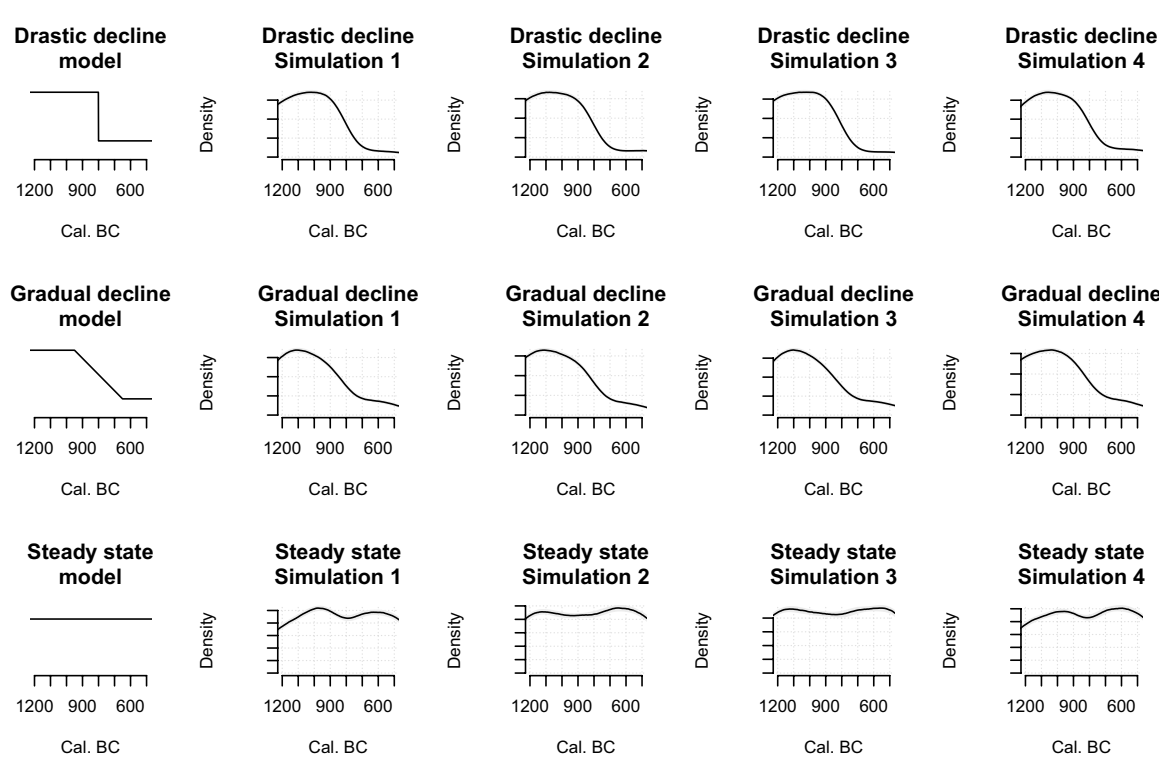

Fig. 11 Density models for multiple simulated sets of radiocarbon dates consisting of a list of 1000 'back calibrated' dates whose distribution in calendar time conforms to the three models presented on the left. Note that whilst KDE models are unable to articulate sudden change, they produce stable patterns that recover the underlying models without the noise inherent to the alternative SPD technique

represented by perturbations in the activity models from southern Italy, France and Britain. Switzerland experiences decline at this point, but no recovery from 700 cal. $\mathrm{BC}$; instead the falling activity levels are sustained into the Iron Age. In Iberia, a similar pattern of intensification and subsequent decline also occurred, although slightly earlier than elsewhere. In their wider European context, Sardinia and Corsica present cases that mirror the rapid downturn seen in central Italy, Scandinavia and Ireland, but the timing of the collapse in the Mediterranean seems slightly earlier. The hypothetical model of drastic decline presented in Fig. 11 is consistent with real archaeological data from a great variety of locations and together they indicate a major mid-ninth-century BC event that impacted human activity across Europe. In some regions this manifests as a decline, in others as an apparent collapse. If real, this is a pattern that must have had a major bearing on the many cultural transitions that were occurring during this period, for example by causing abandonment of some localities and nucleation in others. In the case of central Italy, the period c. 950-800 BC was a period of centralisation into fewer settlements and our data are compatible with multiple ways of modelling this process. Nucleation may have been a response to demographic decline, and a collective solution to the problem of weakening social connections in an otherwise more dispersed settlement system. Alternatively, it may simply reflect a situation where fewer sites are represented by fewer dates. Our resolution of these processes is obviously hampered by the fact that there have been fewer attempts to apply radiocarbon dating to Iron Age, Phoenician and Classical contexts, and the subsequent 'Hallstatt' plateau in the calibration curve. We, however, contend that the pattern observed here for the early first millennium 

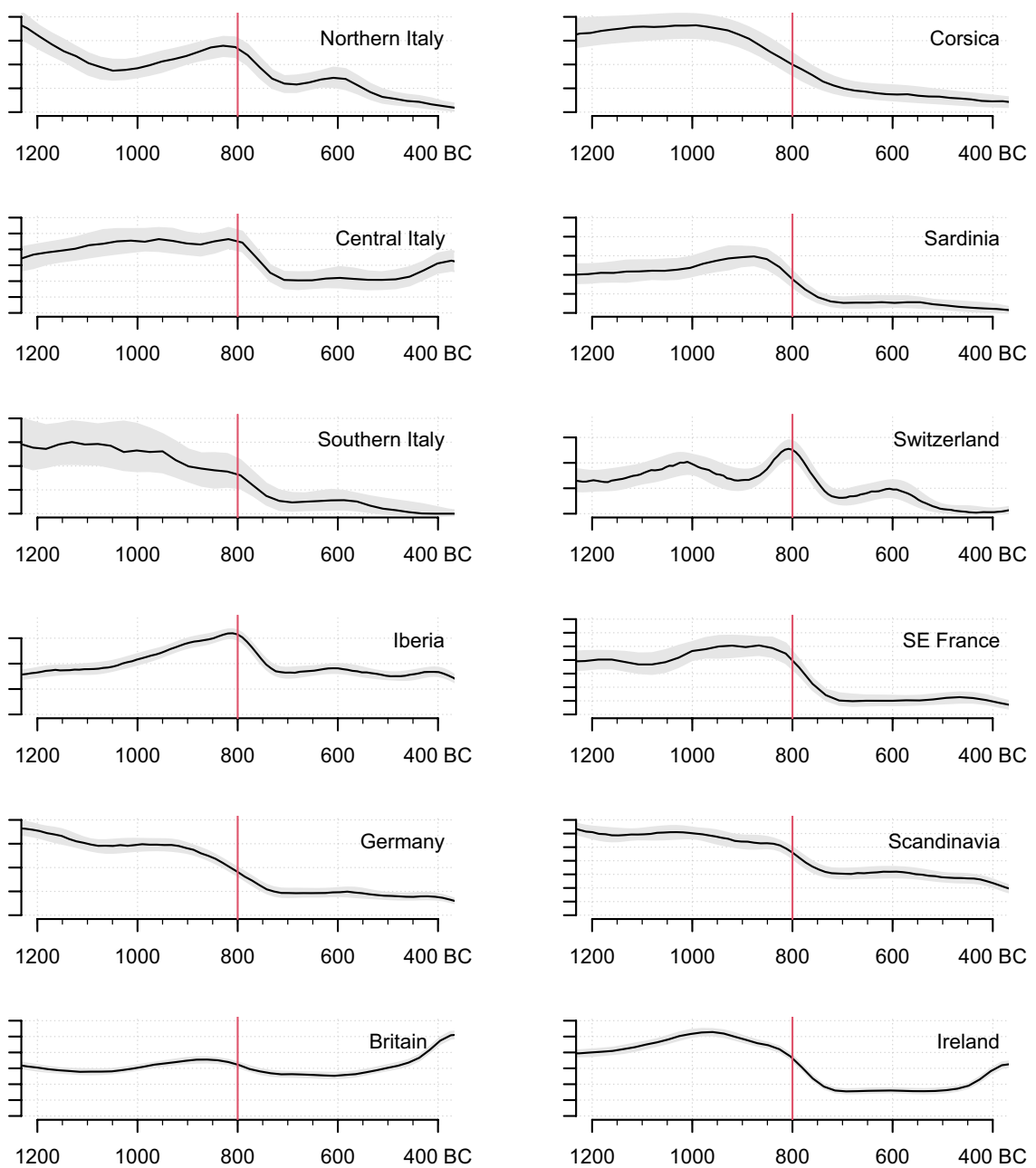

Fig. $12 \mathrm{KDE}$ activity models (30-year bandwidth) for selected European regions at the interface between the Bronze and Iron Ages with 800 BC highlighted. Data sources: Italy, this paper; Britain and Ireland, Bevan et al. (2017); France, the BANADORA database (http://www.arar.mom.fr/banadora/); and other regions, the RADON-B database (http://radon.ufg.uni-kiel.de)

BC is broadly valid, given its occurrence in certain independent and extremely wellresolved radiocarbon datasets (such as Ireland, which is unaffected by such research biases), and highlights both an urgent need to undertake assessments of alternative proxies for activity (such as frequency of pottery finds), and the utility of extending studies of prehistoric demography beyond their usual $750 \mathrm{BC}$ cut-off date. 


\section{Conclusion}

This study presents the first attempt at exploring long-term radiocarbon dated trends, settlement activity and population dynamics across the entire central Mediterranean region. The database used in this study comprises 4608 dates from Italy, France and the Maltese Islands ranging from the Mesolithic to Early Iron Age, which in itself represents an important step towards synthesizing central Mediterranean prehistory. The analysis presented here has shown that whilst some trends were local or regional in character, other events were shared with pan-European phenomena. We have tried to contextualise our results through reference to the archaeological record, palaeoenvironmental studies, and by acknowledging research biases, as well as the picture emerging from recent aDNA studies in the region. Our work has incorporated pre-existing databases of radiocarbon data for comparative purposes because the cost of their analysis has been greatly reduced by the time and effort already invested in them by others. In a similar vein, we offer our central Mediterranean database to the public domain in the hope that it will be useful to future researchers undertaking pan-regional studies in world prehistory.

The low level of human activity during the central Mediterranean Mesolithic acts as a prelude to the beginning of the Neolithic, where the comparative density models for wider Europe (Fig. 4) illustrate similar, but asynchronous, patterns of rising and falling activity. These results suggest an endogenous, historically-determined regimen of local resource exploitation that was a common feature of the wider European Neolithic (cf. Shennan et al., 2013; Timpson et al., 2014). However, the signals also carry evidence for certain events that occurred synchronously in radically different cultural, environmental, and geographical contexts, and in these cases it is difficult to frame an explanation for the observed trends without invoking a climatic cause; our discussion on the apparent influence of climatic factors on erratic fluctuations in anthropogenic activity across the Neolithic in southern Italy stands out here.

In particular, evidence from the south of the Italian peninsula seems to suggest that settlement on the Apulian Tavoliere was so dense and rapid, reaching a level not seen in central or northern Italy, that the growth was simply unsustainable. The results, coupled with the lack of intensive use of the Tavoliere for the remainder of prehistory, may support the suggestion that land exhaustion was a driving factor in this decline, and if anything, emphasize the need to undertake more palaeoenvironmental research on this important landscape.

Taking a broader view, an interesting characteristic of the Neolithic 'boom and bust' pattern in the central Mediterranean is that regions where initial growth was rapid, such as the Tavoliere and the island settings of Malta and Corsica, also declined more quickly once the Early Neolithic peak passed (see Table 3). The pronounced 'boom' in these settings can be best explained by the processes of neolithization, namely sustained migration en masse coupled with strong natural population growth. The correlation between relatively rapid growth and decline in the same regional settings indicates that, as a general rule, rapid growth led to equally rapid decline, which has been interpreted elsewhere for Early Neolithic Europe as the signal of a 'travelling wave' (Silva \& Vander Linden, 2017). A similar symmetry 
in growth and decline occurred during the Late Neolithic 'Temple Period' of the Maltese Islands. We therefore propose a model for the Neolithic whereby rapid prehistoric decline was caused, at least in part, by an unsustainable upward cultural trajectory initiated centuries beforehand.

By contrast, the Copper Age in central and northern Italy was a time of sustained activity levels. Although such models of stationary growth may not contain the intriguing oscillations in activity seen in earlier and later contexts, they are nonetheless interesting as they hint at a world where the economy and population-and by extension rates of food production, fertility and mortality-were held in balance. The reasons for this are probably rooted in social and political conditions that made manifest a pattern of stability and resilience in the face of the many risks common to prehistoric societies everywhere.

Through time, there seems to have been an inverse correlation between activity levels on the Maltese Islands and Sicily, with a decrease on one island signalling an increase on the other. Whilst this can be explained by expansion of people and ideas at given moments, as demonstrated by the spread of the Neolithic, the reciprocal relationship between the Maltese Islands and Sicily after 4000 cal. BC is harder to explain. It may be tempting to hypothesise that these patterns indicate population shifts that occurred between the two (see Bonanno, 1993), but the overlaps in the development and decline of activity in the Maltese Islands and Sicily illustrate that there is not a simple relationship between levels of human activity in the two regions. Similarly, the evidence for Sardinia and Corsica, and to lesser extent northern Italy and southeast France, illustrates the parallel cultural trajectories of these regions, thus emphasizing the importance of looking beyond modern national or political borders when trying to come to terms with patterns in the archaeological record. In this regard, a consideration of the western Balkans will be a valuable future step, especially given the important role of the region in the diffusion of culture and technology during the Neolithic (Conati Barbaro, 2019; Pearce, 2013).

Patterns of activity during the central Mediterranean Bronze Age varied by region, and following initial rapid growth, northern Italy saw steady decline. By contrast, central Italy saw an initial slow decline transformed to steady growth until c. $820 \mathrm{BC}$, when activity levels in most central Mediterranean regions (and beyond) fell dramatically. The causes of this decline were probably rooted in the effects of a worsening climate, changing political and cultural circumstances, and perhaps weakening of agricultural productivity at a time when European society was undergoing restructuring brought about by the introduction of iron. This probably caused activity levels in central Italy to fall to half their previous levels, although from 550 BC they recovered, while in Sardinia the Nuragic period ended rather suddenly. However, our efforts to map out the long-term consequences of the ' $820 \mathrm{BC}$ event' are hampered by the limited number of dates for later time periods.

Such are the constraints of the current study, in that the application of radiocarbon dating has been uneven and has resulted in greater uncertainty about the underlying trends in some regions. However, the results presented here offer a step towards synthesizing the prehistory of a geographical area where comprehensive 
English-language regional syntheses are lacking. Furthermore, the patterns revealed by the analysis illustrate how dynamic the central Mediterranean was. Unlike the similar and predictable patterns of activity that dominate the archaeology of northern Europe, the central Mediterranean was a melting pot of cultures and ideas, within a highly diverse physical landscape. The islands of the central Mediterranean also offer unique microcosms where the pace of development of cultural change in the past can be read from the radiocarbon record and compared to the macro-trends operating in less insular settings. The new results presented in this paper have considerable implications for interpreting demographic history and the ecological relationships between people and their environment, which we hope will stimulate the course of future bioarchaeological and palaeoenvironmental research in the region.

The central Mediterranean landscape is today regarded as an idyll by many; it is certainly rich and diverse, but one recurring trend in the prehistory of its human settlement stands out: since the Neolithic, high levels of human activity and settlement density have not been sustained indefinitely anywhere in this region. Rather, as exemplified in the southern Italian Neolithic, or in the Maltese Islands during the Temple Period, or in Sardinia during the Bronze Age, high activity levels drew society inevitably towards long-term decline when the cumulative demand on resources fell afoul of the capacity of the environment to meet those demands. Some prehistoric societies were more resilient than others, but the recurring pattern was one of instability over the longer term and occasional episodes of crisis. This is a stark reminder from the prehistoric past that the human dimension is as fragile as any other component in an ecosystem, and given our species' long intergenerational period, we tend to be rather slow in the recovery.

\section{Editor's Note}

The publication by JWP of two independently-researched palaeodemographic syntheses covering a similar region and timespan affords a rare opportunity to reflect on the relationship between theories, methods and results in our discipline. In particular, it provides a context for assessing the potential of reproducible research for increasing archaeological knowledge security. In order to make the most of this conjunction, the Editor-in-Chief exceptionally invited each team to consider the other's results. These invitations were accepted and, while the empirical contents of each paper remain unaltered from their peer-reviewed acceptance, each now concludes with a short commentary reflecting on the similarities and differences.

Timothy Taylor, Comenius University in Bratislava, August 2021. 


\section{Commentary: Parkinson et al. (2021) on Palmisano et al. (2021)}

In their paper, Palmisano and colleagues have been more ambitious than we have in framing palaeodemographics front-and-centre in their analysis. Like many works that aggregate radiocarbon dates, they have included attempts to fit their SPDs to demographic models and evaluate these using information criteria. We have attempted something more exploratory and intermediate in scope because we believe dynamic models of changing activity levels remain sensitive to the fact that each moment in time carves out a new fate for itself. After all, the world is more immediately influenced by events occurring adjacently in time and space than events occurring far away or long ago. Hopefully, our two papers will highlight cases where model-based palaeodemography is useful, as well as cases where it is arguably too reductive.

Our papers obviously differ in the wider perspectives they bring to the radiocarbon data. Palmisano et al. have gathered together an impressive number of different regional palaeoclimate records and compared them with the archaeological data, whereas we have drawn on archaeological data from adjacent regions and wider Europe as a kind of 'super-proxy' for environmental change occurring at a global scale. It is our hope that splicing together both sets of analysis will reward interested readers of this journal with their own new, independent insights. Indeed, one of the most important aspects of our work is openness and ensuring there is potential for re-use and re-evaluation. The results of our two studies bear striking similarities to each other, thus validating the theoretical underpinnings, rigour of data collection, and methodological approaches of both. The only major difference we can detect is the relatively higher levels of activity in the Bronze Age in southern Italy reported by Palmisano et al., which indicate either that our counterparts had greater success in gathering dates from this period, or that our database contains a relative wealth of dates for the Neolithic that has skewed our respective models accordingly. Despite this, the overall dynamic identified by both papers is similar, with a cycle of growth and decline occurring throughout the second millennium BC. Because both teams have followed best practice and made their data and code available as supplementary materials, we encourage readers to see whether any recently-published data generate updated models.

Despite their overall conceptual similarity, the two papers have employed different-albeit related-methodological approaches in an attempt to synthesise the radiocarbon data for central Mediterranean prehistory. We feel our Kernel Density Estimation (KDE) method better aids in the identification of shorter-term changes than the Summed Probability Distribution (SPD) and permutation testing approach used by Palmisano et al. The narrower confidence intervals in our KDE models allow us to model growth rates dynamically, which has unexpectedly revealed shared dynamics across several regions (e.g. 3000 BC). This implies there were events in prehistory that were large in geographical scale but generated subtle temporal signals, and KDEs are the best apparatus currently available for detecting these. However, we expect the methods we present here will continue to be developed, by ourselves and others. 
Perhaps the largest departure our papers make from one another is in our interpretations of the data from the first millennium BC. Palmisano et al. have interpreted the reduction in their SPD models as a weakening signal, which totally succumbs to negative research bias by the time 'complex societies' appear (their fig. 11). Whilst we too acknowledge the enormity of the problem of negative bias and 'edge effects', we also point out that there is growth as well as decline in some regions during the early first millennium $\mathrm{BC}$, indicating that a demographic signal may still be present, as it is in other, better resolved, European regions. This opens up a number of interesting thought experiments, such as the idea that Neolithic, Copper Age and Bronze Age societies were perhaps not as demographically limited as they are often assumed to be, and the complex processes that led to state formation may be a response to lower population densities rather than the consequence of rising ones. This all serves to illustrate how little we actually know about prehistoric population levels on any absolute scale, which is a challenge that the two papers make for future research in the central Mediterranean and world prehistory more generally.

Supplementary Information The online version contains supplementary material available at https://doi. org/10.1007/s10963-021-09158-4.

Acknowledgements Eóin W. Parkinson was funded through an AHRC studentship from the University of Cambridge Doctoral Cambridge Partnership. T. Rowan McLaughlin was supported by the European Research Council projects FRAGSUS (323737), PALEO-DEM (683018) and INDUCE (695539) when developing some of the methods used in this paper. Funding for the Maltese data was directly provided by the European Research Council Advanced Grant 323727 'FRAGSUS' (PI Caroline Malone). Carmen Esposito was funded by an AHRC studentship from the Northern Bridge Doctoral Training Partnership, held at Queen's University Belfast. Maps were plotted using public domain data: political boundaries, coastlines and bathythermy from NaturalEarth, and topography from the SRTM. We would also like to thank Graeme Barker, Vitale Sparacello, Cecilia Conati Barbaro, Ruth Whitehouse, Mark Pearce and those in attendance at the 2019 EAA conference session 'Scientific Dating and Central-Western Mediterranean Prehistory' (Bern, Switzerland) for their valuable discussions and insights as we developed this article. Finally, we would like to thank Racer-X and the two anonymous reviewers for their helpful critiques that strengthened this manuscript.

Open Access This article is licensed under a Creative Commons Attribution 4.0 International License, which permits use, sharing, adaptation, distribution and reproduction in any medium or format, as long as you give appropriate credit to the original author(s) and the source, provide a link to the Creative Commons licence, and indicate if changes were made. The images or other third party material in this article are included in the article's Creative Commons licence, unless indicated otherwise in a credit line to the material. If material is not included in the article's Creative Commons licence and your intended use is not permitted by statutory regulation or exceeds the permitted use, you will need to obtain permission directly from the copyright holder. To view a copy of this licence, visit http://creativecommons.org/licen ses/by/4.0/.

\section{References}

Alberti, G. (2013a). A Bayesian 14C chronology of Early and Middle Bronze Age in Sicily: Towards an independent absolute dating. Journal of Archaeological Science, 40(5), 2502-2514. https://doi.org/ 10.1016/J.JAS.2012.08.014 
Alberti, G. (2013b). Issues in the absolute chronology of the Early-Middle Bronze Age transition in Sicily and southern Italy: A Bayesian radiocarbon view. Journal of Quaternary Science, 28(6), 630640. https://doi.org/10.1002/jqs.2659

Albore Livadie, C. (2007). L'età del Bronzo antico e medio nella Campania nord-occidentale. In Atti della XL riunione scientifica IIPP: Strategie di insediamento fra Lazio e Campania in età preistorica e protostorica (Roma, Napoli, Pompei, 30 novembre-3 dicembre 2005) (pp. 179-203). Istituto Italiano di Preistoria e Protostoria.

Albore Livadie, C., Campajola, L., D’Onofrio, A., Moniot, R., Roca, V., Romano, M., Russo, F., \& Terrasi, F. (1998). Evidence of the adverse impact of the Avellino Pumices eruption of Somma-Vesuvius on old Bronze Age sites in the Campania region (Southern Italy). Quaternaire, 9(1), 37-43. https://doi.org/10.3406/quate.1998.2104

Albore Livadie, C., Castaldo, E., Castaldo, N., Cesarano, B., Citro, D., d'Avella, A., Donne, M. D., Pappalardo, M., Pizzano, N., \& Vannata, R. (2010). Le strutture abitative e di servizio dell'insediamento dell'età del ferro di Longola (Poggiomarino, NA). In N. Negroni Catacchio (Ed.), L'alba dell'Etruria: Fenomeni di continuità e trasformazione nei secoli XII-VIII a.C.-Ricerche e scavi (Valentano, VT, Pitigliano, GR, 12-14th Settembre 2008) (pp. 775-785). Centro Studi di Preistoria e Archeologia.

Albore Livadie, C., \& D’Amore, L. (1980). Palma campania (Napoli): Resti di abitato dell'età del bronzo antico. Notizie Degli Scavi Di Antichità, 34, 59-101.

Albore Livadie, C., Pearce, M., Delle Donne, M., \& Pizzano, N. (2019). The effects of the Avellino Pumice eruption on the population of the Early Bronze Age Campanian plain (Southern Italy). Quaternary International, 499, 205-220. https://doi.org/10.1016/J.QUAINT.2018.03.035

Albore Livade, C., \& Vecchio, G. (2020). Nola-Croce del Papa: Un villaggio sepolto dall'eruzione vesuviana delle Pomici di Avellino. Centre Jean Bérard.

Ammerman, A. J., \& Cavalli-Sforza, L. L. (1979). The wave of advance model for the spread of agriculture in Europe. Transformations. https://doi.org/10.1016/B978-0-12-586050-5.50023-3

Antonio, M., Gao, Z., Moots, H., Lucci, M., Candilio, F., et al. (2019). Ancient Rome: A genetic crossroads of Europe and the Mediterranean. Science, 366(6466), 708-714.

Anzidei, A. P., \& Carboni, G. (Eds.). (2020). Roma prima del mito: Abitati e necropoli dal neolitico alla prima eta' dei metalli nel territorio di Roma (VI-III millennio a.C.) (Vol. I). Archaeopress.

Anzidei, A. P., Carboni, G., Castagna, M. A., Celant, A., Cianca, M., Egidi, R., Favoritio, S., Funiciello, R., Giordano, G., Malvone, M., \& Tagliacozzo, A. (2007). L'abitato eneolitico di Osteria del Curato-via Cinquefrondi: Nuovi dati sulle facies archeologiche di Laterza e Ortucchio nel territorio di Roma. In Atti della XL riunione scientifica IIPP: Strategie di insediamento fra Lazio e Campania in età preistorica e protostorica (Roma, Napoli, Pompei, 30 novembre-3 dicembre 2005) (pp. 477-508.). Istituto Italiano di Preistoria e Protostoria.

Anzidei, A. P., Carboni, G., Catalano, P., De Angelis, F., \& Di Giannantonio, S. (2016). The Eneolithic in the territory of Rome: Funerary rituals in necropolises and settlement areas. In O. Rickards \& L. Sarti (Eds.), Biological and cultural heritage of the central-southern Italian population through 30 thousand years (pp. 15-34). UniversItalia.

Anzidei, A. P., Carboni, G., \& Mieli, G. (2012). Il gruppo Roma-Colli Albani: Un decennio di ricerche e studi sulla facies di Rinaldone nel territorio di Roma. In N. Negroni Catacchio (Ed.), L' Etruria dal Paleolitico al Primo Ferro. Lo stato delle ricerche. Atti del $10^{\circ}$ Incontro di studi preistoria e protostoria in Etruria (pp. 197-214). Centro Studi di Preistoria e Archeologia.

Aprile, G., Ingravallo, E., \& Tiberi, I. (2013). Recenti datazioni dalla necropoli di Salve (Lecce). In D. Cocchi Genick (Ed.), Cronologia assoluta e relativa dell'età del rame in Italia (Atti dell'incontro di studi Università di Verona, 25 June 2013) (pp. 149-155). QuiEdit.

Ariano, B., McLaughlin, T. R., Power, R. K., Stock, J. T., Mercieca-Spiteri, B., Stoddart, S., Malone, C., Mattiangeli, V., \& Bradley, D. (in press), aDNA origins of the early Maltese people. In S. Stoddart, P. K. Power, J. E. Thompson, B. Mercieca-Spiteri, T. R. McLaughlin, A. Pace \& C. Malone (Eds.), Temple people: Bioarchaeology, resilience and culture in prehistoric Malta (2 of the ERC-funded FRAGSUS Project). McDonald Institute for Archaeological Research.

Attenbrow, V., \& Hiscock, P. (2015). Dates and demography: Are radiometric dates a robust proxy for long-term prehistoric demographic change? Archaeology in Oceania, 50, 30-36. https://doi.org/10. 1002/arco.5052

Aurino, P. (2013). Al tempo del Gaudo: Riflessioni sull'età del rame in Campania. In D. Cocchi Genick (Ed.), Cronologia assoluta e relativa dell'età del rame in Italia (Atti dell'incontro di studi Università di Verona, 25 June 2013) (pp. 157-171). QuiEdit. 
Bagolini, B. (1980). Introduzione al Neolitico dell'Italia Settentrionale. Grafiche Editoriali Artistiche Pordenonesi.

Bagolini, B. (Ed.). (1981). Il Neolitico e L'età del Rame: Ricerca a Spilamberto-S. Cesario 1977-1980. Comune di Spilamberto.

Bagolini, B., \& Biagi, P. (1990). The radiocarbon chronology of the Neolithic and Copper Age of northern Italy. Oxford Journal of Archaeology, 9(1), 1-23. https://doi.org/10.1111/j.1468-0092.1990. tb00211.x

Baioni, M., \& Poggiani-Keller, R. (2013). L'età del Rame in Lombardia: Un breve quadro di sintesi. In D. Cocchi Genick (Ed.), Cronologia assoluta e relativa dell'età del rame in Italia (Atti dell'incontro di studi Università di Verona, 25 June 2013) (pp. 27-49). QuiEdit.

Barbaro, B. (2010). Insediamenti, aree funerari ed entità territoriali in Etruria meridionale nel Bronzo Finale. All'Insegna del Giglio.

Barfield, L. H. (1971). Northern Italy before Rome. Thames \& Hudson.

Barfield, L. H. (1983). The Chalcolithic cemetery at Manerba del Garda. Antiquity, 57(220), 116-124.

Barfield, L. H. (1994a). The Bronze Age of northern Italy: Recent work and social interpretation. In C. Mathers \& S. Stoddart (Eds.), Development and decline in the Mediterranean Bronze Age (pp. 129-144). J. R. Collis.

Barfield, L. H. (1994b). The Iceman reviewed. Antiquity, 68(258), 10-26.

Barker, G. (1981a). Landscape and society: Prehistoric central Italy. Academic Press.

Barker, G. (1981b). Prehistoric settlement patterns in southeast Italy. In R. Hodges \& G. Barker (Eds.), Archaeology and Italian society: Prehistoric, Roman and medieval studies (pp. 157-165). British Archaeological Reports.

Barker, G. (1999). Hunting and farming in prehistoric Italy: Changing perspectives on landscape and society. Papers of the British School at Rome, 67, 1-36.

Barker, G. (2005). Agriculture, pastoralism and mediterranean landscapes in prehistory. In: E. Blake \& B. Knapp (Eds.). The Archaeology of Mediterranean Prehistory (pp. 46-76). London: Wiley-Blackwell.

Barker, G., \& Stoddart, S. (1994). The Bronze Age of central Italy: C. 2000 BC. In C. Mathers \& S. Stoddart (Eds.), Development and decline in the Mediterranean Bronze Age (pp. 145-166). J. R. Collis.

Barone, G., Gullì, D., Mazzoleni, P., Raneri, S., \& Tanasi, D. (2010). Archaeometric identification of Maltese imports in prehistoric Sicily: Żebbug phase pottery from Licata-Caduta (Agrigento). Malta Archaeological Review, 10, 23-30.

Barratt, R. P., Malone, C., McLaughlin, T. R., \& Parkinson, E. W. (2020). Hypogea and the clubhouse: Neolithic Malta's houses of the living and houses of the dead. In A. Barclay, J. Leary, \& D. Field (Eds.), Houses of the dead? Neolithic studies group seminar papers (pp. 15-37). Oxbow.

Battentier, J., Binder, D., Guillon, S., Maggi, R., Negrino, F., Sénépart, I., Tozzi, C., Théry-Parisot, I., \& Delhon, C. (2018). The environment of the last hunters-gatherers and first agro-pastoralists in the western Mediterranean region, between the Rhone and the Northern Apennines (7th-6th millennium cal. BCE): Attractiveness of the landscape units and settlement patterns. Quaternary Science Reviews, 184, 167-182.

Berger, J., Shennan, S., Woodbridge, J., Palmisano, A., Mazier, F., Nuninger, L., Guillon, S., Doyen, E., Bégeot, C., Andrieu-Ponel, V., Azuara, J., Bevan, A., Fyfe, R., \& Roberts, C. (2019). Holocene land cover and population dynamics in Southern France. The Holocene, 29(5), 776-798. https:// doi.org/10.1177/0959683619826698

Bernabò Brea, M., Bianchi, P., Bronzoni, L., \& Mazzieri, P. (2011). Abitati dell'età del rame nel Parmense. In D. Cocchi Genick (Ed.), Atti della XLIII riunione scientifica IIPP_L'età del rame in Italia (Bologna, 26-29 novembre 2008): Dedicata a Gianni Bailo Modesti (pp. 233-239). Istituto Italiano di Preistoria e Protostoria.

Bernabò Brea, M., Cardarelli, A., \& Cremaschi, M. (1997). Il crollo del sistema terramaricolo. In M. Bernabò Brea, A. Cardarelli \& M., Cremaschi (Eds.), Le Terramare. La più antica civiltà padana. Modena: Catalogo della Mostra (pp. 745-756.). Electa.

Bernabò Brea, M., Cardarelli, A., \& Cremaschi, M. (2018). L'Emilia tra antica e recente età del Bronzo. In M. Bernabò Brea (Ed.), Preistoria e protostoria dell'Emilia Romagna (vol. II, età del Bronzo, età del Ferro) (pp. 9-32). Istituto Italiano di Preistoria e Protostoria.

Berni, L., Ferrari, A., Mazzieri, P., \& Steffè, G. (2011). Nuove ricerche nell'insediamento eneolitico di S. Cesario sul Panaro, Cava Marchi (Modena). In D. Cocchi Genick (Ed.), Atti della XLIII riunione scientifica IIPP_L'età del rame in Italia (Bologna, 26-29 novembre 2008): Dedicata a Gianni Bailo Modesti (pp. 613-618). Istituto Italiano di Preistoria e Protostoria. 
Bevan, A., Colledge, S., Fuller, D., Fyfe, R., Shennan, S., \& Stevens, C. (2017). Holocene fluctuations in human population demonstrate repeated links to food production and climate. Proceedings of the National Academy of Sciences of the United States of America, 114(49), E10524-E10531. https:// doi.org/10.1073/pnas.1709190114

Bevan, A., \& Crema, E. R. (2020) rcarbon v1.3.1: Methods for calibrating and analysing radiocarbon dates. Published R package, https://CRAN.R-project.org/package=rcarbon

Biagi, P., Maggi, R., \& Nisbet, R. (1988). Liguria: 11,000-7000 BP. In C. Bonsall (Ed.), The Mesolithic in Europe: Papers presented at the third international symposium (Edinburgh, 1985) (pp. 533-540). John Donald.

Biagi, P., Starnini, E., Borič, D., \& Mazzucco, N. (2020). Early Neolithic settlement of the Po Plain (northern Italy): Vhò and related sites. Documenta Praehistorica, 47, 192-221.

Biancofiore, F. (1967). La necropoli eneolitica di Laterza, origini e sviluppo dei gruppi 'protoappenninici' in Apulia. Origini, 1, 195-300.

Bietti Sestieri, A. M. (1997). Il territorio padano dopo le terramare. In M. Bernabò Brea, A. Cardarelli \& M. Cremaschi (Eds.), Le Terramare. La più antica civiltà padana. Modena: Catalogo della Mostra (pp.757-771). Electa.

Bietti Sestieri, A. M. (2010). L'Italia nell'età del Bronzo e del Ferro: Dalle palafitte a Romolo (2200-700 a.C.). Carocci.

Bietti Sestieri, A. M. (2012). Il Villanoviano: Un problema archeologico di storia mediterranea. In V. Belelli (Ed.), Le Origini degli Etruschi: Storia antropologia e archeologia (pp. 249-277). L’Erma di Bretschneider.

Bietti Sestieri, A. M. (2013a). Peninsular Italy. In H. Fokkens \& A. Harding (Eds.), The Oxford handbook of the European Bronze Age (pp. 706-718). Oxford University Press. https://doi.org/10.1093/oxfor $\mathrm{dhb} / 9780199572861.013 .0035$

Bietti Sestieri, A. M. (2013b). The Bronze Age in Sicily. In H. Fokkens \& A. Harding (Eds.), The Oxford handbook of the European Bronze Age (pp. 653-664). Oxford University Press. https://doi.org/10. 1093/oxfordhb/9780199572861.013.0036

Binder, D., Lanos, P., Angeli, L., Gomart, L., Guilaine, J., Manen, C., Maggi, R., Muntoni, I., Panelli, C., Radi, G., Tozzi, C., Arobba, A., Battentier, J., Brandaglia, M., Bouby, L., Briois, F., Carré, A., Delhon, C., Gourichon, L., Marinval, P., Nisbet, R., Rossi, S., Rowley-Conwy, P., \& Thiebault, S. (2017). Modelling the earliest north-western dispersal of Mediterranean impressed wares: New dates and Bayesian chronological model. Documenta Praehistorica, 44, 54-77. https://doi.org/10. 4312/dp. 44.4

Blake, E. (1997). Strategic symbolism: Minature nuraghi of Sardinia. Journal of Mediterranean Archaeology, 10(2), 151-164.

Blake, E. (2014). Social networks and regional identity in Bronze Age Italy. Cambridge University Press.

Blake, E. (2015). Late Bronze Age Sardinia: Acephalous cohesion. In A. B. Knapp \& P. van Dommelen (Eds.), The Cambridge prehistory of the Bronze and Iron Age Mediterranean (pp. 96-108). Cambridge University Press. https://doi.org/10.1017/CHO9781139028387.009

Bocquet-Appel, J. P. (2002). Paleoanthropological traces of a Neolithic demographic transition. Current Anthropology, 43(4), 637-650.

Bonanno, A. (1993). Tarxien and Tarxien cemetery: Break or continuity between Temple Period and Bronze Age in Malta? Mediterrâneo, 2, 35-47.

Bonanno, A. (2000). Early colonisation of the Maltese Islands: The status quaestionis. In V. M. Guerrero \& S. Gomes (Eds.), Colonización humana en ambientes insulares: Interacción con el medio y adaptación cultural (pp. 323-337). Universita de les Illes Balears.

Bonanno, A., Gouder, T., Malone, C., \& Stoddart, S. (1990). Monuments in an island society: The Maltese context. World Archaeology, 22(2), 190-205.

Brogan, C., Parkinson, E. W., McLaughlin, T. R., French, C., \& Malone, C. (2020). Skorba. In C. Malone, R. Grima, T. R. McLaughlin, E. W. Parkinson, S. Stoddart, \& N. Vella (Eds.), Temple places: Excavating cultural sustainability in prehistoric Malta (Volume 2 of the ERC-funded FRAGSUS Project) (pp. 227-244). McDonald Institute for Archaeological Research.

Bronk Ramsey, C. (2017). Methods for summarizing radiocarbon datasets. Radiocarbon, 59(6), 1-25.

Brown, K. (2003). Aerial archaeology of the Tavoliere: The Italian air photographic record and the Riley archive. Accordia Research Papers, 9, 123-146.

Brown, K., \& Alexander, C. (2013). Once is not enough: Were there two Neolithic colonisations of southern Italy? A Bayesian analysis of the radiocarbon evidence. Accordia Research Papers: Rethinking the Italian Neolithic, 13, 31-56. 
Brown, W. A. (2017). They don't look different, but they're not the same: Formal resemblance and interpretive disparity in the construction of temporal frequency distributions. http://arxiv.org/abs/1708. 00535

Burleigh, R. (1984). Radiocarbon dates for the western Mediterranean region. In W. H. Waldren (Ed.), The Deya conference of prehistory: Early settlement in the western Mediterranean islands and their peripheral areas (Part II) (pp. 277-290). British Archaeological Reports.

Capuzzo, G. (2014). Space-temporal analysis of radiocarbon evidence and associated archaeological record: From the Danube to Ebro rivers and from Bronze to Iron Ages. Unpublished Ph.D. Thesis: University of Barcelona.

Capuzzo, G., Boaretto, E., \& Barceló, J. A. (2014). EUBAR: A Database of 14C Measurements for the European Bronze Age. A Bayesian analysis of 14C-dated archaeological contexts from northern Italy and southern France. Radiocarbon, 56(2), 851-869. https://doi.org/10.2458/56.17453

Capuzzo, G., Zanon, M., Dal Corso, M., Kirleis, W., \& Barceló, J. A. (2018). Highly diverse Bronze Age population dynamics in central-southern Europe and their response to regional climatic patterns. PLOS ONE. https://doi.org/10.1371/journal.pone.0200709

Carboni, G. (2020a). Eneolitico medio: La facies del Gaudo nel territorio di Roma e nel Lazio centromeridionale (ca. 3330-2860 a.C.). In Anzidei, A. P., \& Carboni, G. (Eds.), Roma prima del mito: Abitati e necropoli dal neolitico alla prima eta' dei metalli nel territorio di Roma (VI-III millennio a.C.) (Vol. II) (pp. 89-148). Archaeopress.

Carboni, G. (2020b). Eneolitico recente: La facies di Laterza nel territorio di Roma ed aree limitrofe (ca. 2820-2620 a.C.). In Anzidei, A. P., \& Carboni, G. (Eds.), Roma prima del mito: Abitati e necropoli dal neolitico alla prima eta' dei metalli nel territorio di Roma (VI-III millennio a.C.) (Vol. II) (pp. 149-202). Oxford: Archaeopress.

Carboni, G., \& Anzidei, A. P. (2013). L'eneolitico recente e finale nel Lazio centro-meridionale: Una puntualizzazione sullo sviluppo e la durata di alcuni aspetti culturali sulla base delle più recenti datazioni radiometriche. In D. Cocchi Genick (Ed.), Cronologia assoluta e relativa dell'età del rame in Italia (Atti dell'incontro di studi Università di Verona, 25 June 2013) (pp. 91-118). QuiEdit.

Cardarelli, A. (2009). The collapse of the Terramare culture and growth of new economic and social systems during the Late Bronze Age in Italy. Scienze Dell'antichità, 15, 429-445.

Cardarelli, A. (2015). Different forms of social inequality in Bronze Age Italy. Origini, 38, 151-200.

Cardarelli, A. (2018). Before the city: The last villages and proto-urban centres between the Po and Tiber rivers. Origini, 42, 359-415.

Cardarelli, A., Bettelli, M., Di Renzoni, A., Silvestrini, M., Venanzoni, I., Cruciani, M., Ialongo, N., Schiappelli, A., Arena, A., Macerola, F., Tavolini, C., Montalvo Puente, C., \& Lago, G. (2017). Nuove ricerche nell'abitato della tarda età del Bronzo di Monte Croce Guardia (Arcevia-AN): Scavi 2015-2016. Rivista Di Scienze Preistoriche, 67, 321-380.

Carleton, W. C., \& Groucutt, H. W. (2021). Sum things are not what they seem: Problems with point-wise interpretations and quantitative analyses of proxies based on aggregated radiocarbon dates. The Holocene, 31(4), 630-643.

Castellana, G. (1985). Il villaggio neolitico di Piano Vento nel territorio di Palma di Montechiaro (Agrigento). In Atti della XXVI Riunione Scientifica dell'Istituto Italiano di Preistoria e Protostoria (pp. 147-172). Istituto Italiano di Preistoria e Protostoria.

Castellana, G. (Ed.). (1995). La necropoli protoeneolitica di Piano Vento nel territorio Palma di Montechiaro. Regione Siciliana.

Cavazzuti, C., Skeates, R., Millard, A. R., Nowell, G., Peterkin, J., Bernabò Brea, M., Cardarelli, A., \& Salzani, L. (2019). Flows of people in villages and large centres in Bronze Age Italy through strontium and oxygen isotopes. PLoS ONE. https://doi.org/10.1371/journal.pone.0209693

Cazzella, A., \& Moscoloni, M. (Eds.). (1999). Conelle di Arcevia: Un Insediamento Eneolitico nelle Marche-I. Lo scavo, la ceramica, i manufatti metallici, i resti organici. Gangemi Editore.

Cazzella, A., \& Moscoloni, M. (2012). L'età del rame in Sicilia. In Atti della XLI Riunione Scientifica: Dai Ciclopi agli Ecisti. Società e territorio nella Sicilia preistorica e protostorica (pp. 57-80). Istituto Italiano di Preistoria e Protostoria.

Cazzella, A., \& Recchia, G. (2014). The Copper Age ditched settlement at Conelle di Arcevia (central Italy). In C. A. de Valera (Ed.), Recent prehistoric enclosures and funerary practices in Europe: Proceedings of the international meeting held at the Gulbenkian Foundation (Lisbon, Portugal, November 2012) (pp. 129-138). Archaeopress. 
Chiang, C., Marcus, J. H., Sidore, C., Biddanda, A., Al-Asadi, H., Zoledziewska, M., Pitzalis, M., Busonero, F., Maschio, A., Pistis, G., Steri, M., Angius, A., Lohmueller, K. E., Abecasis, G. R., Schlessinger, D., Cucca, F., \& Novembre, J. (2018). Genomic history of the Sardinian population. Nature Genetics, 50(10), 1426-1434.

Cocchi Genick, D. (Ed.). (2013). Cronologia assoluta e relativa dell'età del rame in Italia (Atti dell'incontro di studi Università di Verona, 25 Giugno 2013). QuiEdit.

Conati Barbaro, C. (2019). Il fuoco e la memoria: I forni neolitici di Portonovo. Museo e Istituto Fiorentino di Preistoria.

Contreras, D. A., \& Meadows, J. (2014). Summed radiocarbon calibrations as a population proxy: A critical evaluation using a realistic simulation approach. Journal of Archaeological Science, 52, 591-608. https://doi.org/10.1016/j.jas.2014.05.030

Costa, L., Vigne, J.D., Bocherens, H., Desse-Berset, N., Heinz, C., de Lanfranchi, F., Magdeleine, J., Raus, M.P., Thiebault, S., \& Tozzi, C. (2003). Early settlement on Tyrrhenian islands (8th millennium cal. BC): Mesolithic adaption to local resources in Corsica and northern Sardinia. In L. Larsson, H. Kindgren, K. Knutsson, D. Loeffer, D., \& A. Akerlund (Eds.), Mesolithic on the move: Papers presented at the Sixth International Conference on the Mesolithic in Europe (Stockholm, 2000) (pp. 3-10). Oxbow.

Crema, E., Bevan, A., \& Shennan, S. (2017). Spatio-temporal approaches to archaeological radiocarbon dates. Journal of Archaeological Science, 87, 1-9.

Cremaschi, M., Mercuri, A. M., \& Torri., P., Florenzano, A., Pizzi, C., Marchesini, M., \& Zerboni, A. . (2016). Climate change versus land management in the Po Plain (Northern Italy) during the Bronze Age: New insights from the VP/VG sequence of the Terramara Santa Rosa di Poviglio. Quaternary Science Reviews, 136, 153-172. https://doi.org/10.1016/j.quascirev.2015.08.011

Cremaschi, M., Pizzi, C., \& Valsecchi, V. (2006). Water management and land use in the terramare and a possible climatic co-factor in their abandonment: The case study of the terramara of Poviglio Santa Rosa (northern Italy). Quaternary International, 151(1), 87-98. https://doi.org/10.1016/J. QUAINT.2006.01.020

Cullen, L. M. (1974-1975). Population trends in seventeenth-century Ireland. Economic and Social Review, 6, 149-165.

Cupitò, M., Lotto, D., \& Facchin, A. (2015). Dinamiche di popolamento e modelli di organizzazione del territorio nella bassa pianura veneta compresa tra Adige e Tagliamento durante l'Età del Bronzo. In G. Leonardi \& V. Tinè (Eds.), Preistoria e protostoria del Veneto (pp. 295-306). Istituto Italiano di Preistoria e Protostoria.

D’Amore, G., Di Marco, S., Di Salvo, R., Messina, A., \& Sineo, L. (2010a). Early human peopling of Sicily: Evidence from the Mesolithic skeletal remains from Grotta d'Oriente. Annals of Human Biology, 37(3), 403-426. https://doi.org/10.3109/03014461003712947

D’Amore, G., Di Marco, S., Floris, G., Pacciani, E., \& Sanna, E. (2010b). Craniofacial morphometric variation and the biological history of the peopling of Sardinia. Homo, 61(6), 385-412.

Delano Smith, C. (1978). Daunia vetus: Terra, vita e mutamenti sulle coste del Tavoliere. Amministrazione Provinciale di Capitanata.

De Marinis, R. C. (1997). The Eneolithic cemetery of Remedello Sotto (BS) and the relative and absolute chronology of the Copper Age in northern Italy. Notizie Archeologiche Bergomensi, 5, 33-51.

Demurtas, L. M., \& Demurtas, S. (1992). Tipologie nuraghiche: I protonuraghi con corridoio passante. In R. H. Tykot \& T. K. Andrew (Eds.), Sardinia in the Mediterranean: A footprint in the sea (pp. 176-184). Sheffield Academic Press.

Depalmas, A. (2009a). Il bronzo medio della Sardegna. In Atti della XLIV Riunione Scientifica: La preistoria e la protostoria della Sardegna (Cagliari, Barumini, Sassari, 23-28 novembre 2009). Volume I : Relazioni generali (pp. 124-129). Istituto Italiano di Preistoria e Protostoria.

Depalmas, A. (2009b). Il bronzo recente della Sardegna. In Atti della XLIV Riunione Scientifica: La preistoria e la protostoria della Sardegna (Cagliari, Barumini, Sassari, 23-28 novembre 2009). Volume I : Relazioni generali (pp. 112-140). Istituto Italiano di Preistoria e Protostoria.

Depalmas, A. (2009c). Il bronzo finale della Sardegna. In Atti della XLIV Riunione Scientifica : La preistoria e la protostoria della Sardegna (Cagliari, Barumini, Sassari, 23-28 novembre 2009). Volume I : Relazioni generali (pp. 141-160). Istituto Italiano di Preistoria e Protostoria.

Despott, G. (1917). Excavations conducted at Ghar Dalam (Malta) in the summer of 1917. Journal of the Royal Anthropological Institute of Great Britain and Ireland, 48, 214-221.

Di Gennaro, F. (1986). Forme di insediamento tra Tevere e Fiora dal Bronzo Finale al principio dell'età del ferro. Olschki. 
Di Gennaro, F. (1996). Protovillanoviano. Enciclopedia dell'arte antica classica e orientale, 488-496.

Di Gennaro, F., \& Barbaro, B. (2008). Territori e paesaggi mediotirrenici nella mente dei protostorici. In N. Negroni Catacchio (Ed.), Preistoria e Protostoria in Etruria: Paesaggi reali e paesaggi mentali. Ricerche e scavi (Atti dell'Ottavo Incontro di Studi) (pp. 117-128). Centro di Studi di Preistoria e Archeologia.

Di Gennaro, F., \& Pacciarelli, M. (1992). Un territorio-campione nella valle del Mignone (Prov. di Roma e Viterbo). Rassegna Di Archeologia, 10, 968-699.

Di Lorenzo, H., Di Vito, M., Talamo, P., Bishop, J., Castaldo, N., de Vita, S., Nave, R., \& Pacciarelli, M. (2013). The impact of the Pomici di Avellino Plinian eruption of Vesuvius on Early and Middle Bronze Age human settlement in Campania (southern Italy). Tagungen Des Landesmuseums Für Vorgeschichte, Halle, 9, 253-265.

Di Vito, M. A., Talamo, P., de Vita, S., Ruocco, I., Zanchetta, G., \& Cesarano, M. (2019). Dynamics and effects of the Vesuvius Pomici di Avellino Plinian eruption and related phenomena on the Bronze Age landscape of Campania region (southern Italy). Quaternary International, 499(B), 231-224.

Dolfini, A. (2010). The origins of metallurgy in central Italy: New radiometric evidence. Antiquity, 84(325), 707-723.

Dolfini, A. (2013). The Neolithic beginnings of metallurgy in the central Mediterranean region. Accordia Research Papers, 13, 131-151.

Dolfini, A. (2015). Neolithic and Copper Age mortuary practices in the Italian peninsula: Change of meaning or change of medium? In J. R. Brandt, M. Prusac, \& H. Roland (Eds.), Death and changing rituals: Function and meaning in ancient funerary practices (pp. 17-44). Oxbow.

Dolfini, A. (2020). From the Neolithic to the Bronze Age in central Italy: Settlement, burial, and social change at the dawn of metal production. Journal of Archaeological Research, 28, 503-556.

Dyson, S. L., \& Rowland, R. J. (2007). Archaeology and history in Sardinia from the Stone Age to the Middle Ages: Shepherds, sailors, and conquerors. University of Pennsylvania Museum of Archaeology and Anthropology.

Edinborough, K., Porčić, M., Martindale, M., Brown, T. J., Supernant, K., \& Ames, K. M. (2017). Radiocarbon test for demographic events in written and oral history. Proceedings of the National Academy of Sciences of the United States of America, 114(47), 12436-12441. https://doi.org/10.1073/ pnas.1713012114

Evans, J. (1971). The prehistoric antiquities of the Maltese Islands. Athlone.

Fernandes, D. M., Mittnik, A., Olalde, I., Lazaridis, I., Cheronet, O., et al. (2020). The spread of steppe and Iranian-related ancestry in the islands of the western Mediterranean. Nature Ecolology \& Evolution, 4, 334-345.

Fernandez-Lopez de Pablo, J., Gutiérrez-Roig, M., Gómez-Puche, M., McLaughlin, T. R., Silva, F., \& Lozano, S. (2019). Palaeodemographic modelling supports a population bottleneck during the Pleistocene-Holocene transition in Iberia. Nature Communications. https://doi.org/10.1038/ s41467-019-09833-3

Ferrari, A., Forenbaher, S., Micheli, R., Kokelj, M., Pessina, A., Velušček, A., \& Visentini, P. (2018). Neolithic and Eneolithic of Caput Adriae. In E. Borgna, P. Càssola Guida, \& S. Corazza (Eds.), Preistoria e protostoria del Caput Adriae (pp. 61-74). Istituto Italiano di Preistoria e Protostoria.

Festi, D., Tecchiati, U., Steiner, H., \& Oeggl, K. (2011). The Late Neolithic settlement of Latsch, Vinschgau, northern Italy: Subsistence of a settlement contemporary with the Alpine Iceman, and located in his valley of origin. Vegetation History and Archaeobotany, 20(5), 367-379. https://doi. org/10.1007/s00334-011-0308-0

Fiorentino, G., Caldara, M., De Santis, V., D’Oronzo, C., Muntoni, I. M., Simone, O., Primavera, M., \& Radina, F. (2013). Climate changes and human-environment interactions in the Apulia region of southeastern Italy during the Neolithic period. The Holocene, 23(9), 1297-1316. https://doi.org/10. $1177 / 0959683613486942$

Fontana, F., Ferrari, S., \& Visentin, D. (2013). A review on the Mesolithic of the Emilian Apennines and southern Po Plain. Preistoria Alpina, 47, 85-96.

Fontana, F., \& Visentin, D. (2016). Between the Venetian Alps and the Emilian Apennines (northern Italy): Highland vs. lowland occupation in the early Mesolithic. Quaternary International, 423, 266-278. https://doi.org/10.1016/J.QUAINT.2015.12.014

Forenbaher, S., \& Miracle, P. (2005). The spread of farming in the eastern Adriatic. Antiquity, 79(305), $514-538$.

Franco, C. (2016). Excavations at the high altitude Mesolithic site of Pian de La Lóra (Val CivettaVenetian Dolomites, Italy). Preistoria Alpina, 48, 83-87. 
Freeman, J., Byers, D., Robinson, E., \& Kelly, R. (2018). Culture process and the interpretation of radiocarbon data. Radiocarbon, 60(2), 453-467.

French, C., Hunt, C., Farrell, M., Fenech, K., McLaughlin, T. R., Grima, R., Vella, N., Schembri, P., Stoddart, S., \& Malone, C. (2020). Conclusions. In C. French, C. O. Hunt, R. Grima, T. R. McLaughlin, S. Stoddart, \& C. Malone (Eds.), Temple landscapes: Fragility, change and resilience of Holocene environments in the Maltese Islands (Volume 2 of the ERC-funded FRAGSUS Project) (pp. 303324). McDonald Institute for Archaeological Research.

French, C., Taylor, S., McLaughlin, R., Cresswell, A., Kinnaird, T., Sanderson, D., Stoddart, S., \& Malone, C. (2018). A Neolithic palaeo-catena for the Xaghra Upper Coralline Limestone plateau of Gozo, Malta, and its implications for past soil development and land use. CATENA, 171, 337-358. https://doi.org/10.1016/j.catena.2018.07.039

Fugazzola Delpino, M. A., Manfredini, A., Martini, F., Radi, G., Sarti, L., \& Silvestrini, M. (2003a). Insediamenti e strutture neolitiche ed eneilitiche dell'italia centrale. In Atti della XXXV riunione scientifica IIPP: Le comunità della preistoria italiana studi e ricerche sul neolitico e le età dei metalli (Castello di Lipari, Chiesa di S. Caterina, 2-7 hiugno 2000). In memoria di Luigi Bernabò Brea (pp. 93-112). Istituto Italiano di Preistoria e Protostoria.

Fugazzola Delpino, M. A., Salerno, A., Tagliacozzo, A., Tinè, V., \& Vanzetti, A. (2003b). Una comunità della facies di laterza nella pianura campana: L'area 'forum' di Gricignano-US Navy (CE). In Atti della XXXV riunione scientifica IIPP: Le comunità della preistoria italiana studi e ricerche sul neolitico e le età dei metalli (castello di lipari, chiesa di s. caterina, 2-7 hiugno 2000). in memoria di Luigi Bernabò Brea (pp. 199-214). Istituto Italiano di Preistoria e Protostoria.

Giannitrapani, E. (2016). The making of sacred and funerary landscapes in central Sicily between the 6th and the 1st millennium BC. In E. Herring \& E. O'Donovan (Eds.), The archaeology of death: Proceedings of the Seventh Conference of Italian Archaeology (National University of Ireland, Galway, April 16-18, 2016) (pp. 371-382). Archaeopress.

Giannitrapani, E., Ianni, F., Chilardi, S., \& Anguilano, L. (2014). Case Bastione: A prehistoric settlement in the Erei uplands (central Sicily). Origini, 35, 181-211.

Gili, S., Lull, V., Micó, R., Rihuete, C., \& Risch, R. (2006). An island decides: Megalithic burial rites on Menorca. Antiquity, 80(310), 829-842. https://doi.org/10.1017/S0003598X0009445X

Giola, P., Boccuccia, P., \& Minniti, C. (2007). L'insediamento eneolitico di Casale Massima (Roma): La seconda campagna di scavo. In Strategie di insediamento fra Lazio e Campania in età preistorica e protostorica: Atti della XL riunione scientifica (Roma, Napoli, Pompei, 30 novembre-3 dicembre 2005) (pp. 611-614). Istituto Italiano di Preistoria e Protostoria.

Grima, R. (2002). Monuments and landscapes in late Neolithic Malta. Archaeology International, 6, 25-28.

Grima, R. (2008). Landscape, territories, and the life-histories of monuments in Temple Period Malta. Journal of Mediterranean Archaeology, 21(1), 35-56. https://doi.org/10.1558/jmea.2008.v21i1.35

Grima, R., Stoddart, S., Hunt, C. O., French, C., McLaughlin, T. R., \& Malone, C. (2020). Cultural landscapes in the changing environments from 6000 to 2000 BC. In C. French, C. O. Hunt, R. Grima, T. R. McLaughlin, S. Stoddart, \& C. Malone (Eds.), Temple landscapes: Fragility, change and resilience of Holocene environments in the Maltese Islands (Volume 2 of the ERC-funded FRAGSUS Project) (pp. 223-238). McDonald Institute for Archaeological Research.

Guidi, A. (2010). The historical development of Italian prehistoric archaeology: A brief outline. Bulletin of the History of Archaeology, 20(2), 13-21. https://doi.org/10.5334/bha.20203

Guilaine, J., Radi, G., \& Angeli, L. (2019). La néolithisation de l'Italie du sud-est. Eurasian Prehistory, 15(1-2), 101-144.

Gullì, D. (2011). Tipologia e distribuzione dell'insediamento eneolitico nel territorio agrigentino. In D. Cocchi Genick (Ed.), Atti della XLIII riunione scientifica IIPP: L'età del rame in Italia (Bologna, 26-29 novembre 2008). Dedicata a Gianni Bailo Modesti (pp. 691-696). Istituto Italiano di Preistoria e Protostoria.

Gullì, D. (2014). La necropoli preistorica di contrada Scintilia: Dallo scavo alla divulgazione. In D. Gullì (Ed.), Storie Sepolte: Riti, culti e vita quotidiana all'alba del IV millennio a.C. La necropoli di contrada Scintilia di Favara (pp. 11-18). Regione Siciliana.

Haynes, C. V. (1969). The earliest Americans: New developments increase the known antiquity of man in the New World but leave many problems unsolved. Science, 166(3906), 709-715.

Hinz, M., Feeser, I., Sjögren, K., \& Müller, J. (2012). Demography and the intensity of cultural activities: An evaluation of Funnel Beaker societies (4200-2800 cal BC). Journal of Archaeological Science, 39, 3331-3340. https://doi.org/10.1016/j.jas.2012.05.028 
Ialongo, N. (2018). Crisis and recovery: The cost of sustainable development in Nuragic Sardinia. European Journal of Archaeology, 21(1), 18-38.

Ingravallo, E. (1980). L'insediamento eneolitico di Pizzica Pantanello presso metaponto (Basilicata). Atti Della Società Toscana Di Scienze Naturali, 87, 317-327.

Jones, G. D. B. (Ed.). (1987). Apulia. Volume I Neolithic settlement in the Tavoliere. Society of Antiquities.

Jørgensen, E. K. (2018). The palaeodemographic and environmental dynamics of prehistoric Arctic Norway: An overview of human-climate covariation. Quaternary International, 549, 36-51. https:// doi.org/10.1016/J.QUAINT.2018.05.014

Klob, M. J. (2005). The genesis of monuments among the Mediterranean Islands. In E. Blake \& B. A. Knapp (Eds.), The archaeology of Mediterranean prehistory (pp. 156-179). Blackwell.

Kompatscher, K., Hrozny Kompatscher, N., Bassetti, M., Castiglioni, E., \& Rottoli, M. (2016). Mesolithic settlement and mobility patterns at high altitudes: The site of Staller Sattel STS 4A (South Tyrol, Italy). Quaternary International, 423, 23-48. https://doi.org/10.1016/J.QUAINT.2015.12.090

Lai, L. (2008). The interplay of economic, climatic and cultural change investigated through isotopic analysis of bone tissue: The case of Sardinia 4000-1900 BC. Unpublished Ph.D. thesis: University of Florida. https://doi.org/10.1017/CBO9781107415324.004

Leighton, R. (1999). Sicily before history: An archaeological survey from the Palaeolithic to the Iron Age. Cornell University Press.

Leighton, R. (2005). Later prehistoric settlement patterns in Sicily: Old paradigms and new surveys. European Journal of Archaeology, 8(3), 261-287.

Lilliu, G. (1963). La Civiltà dei Sardi: Dal Neolitico all'età dei Nuraghi. ERI.

Lo Schiavo, F. (2013). The Bronze Age in Sardinia. In H. Fokkens \& A. Harding (Eds.), The Oxford handbook of the European Bronze Age (pp. 668-691). Oxford University Press. https://doi.org/10. 1093/oxfordhb/9780199572861.013.0037

Lo Vetro, D., Colonnese, A. C., Mannino, M., Kenneth, T., Di Guisseppe, Z., \& Martini, F. (2016). The Mesolithic occupation at Isolidda (San Vito Lo Capo), Sicily. Preistoria Alpina, 48, 237-243.

Lo Vetro, D., \& Martini, F. (2016). Mesolithic in central-southern Italy: Overview of lithic productions. Quaternary International, 423, 279-302.

Lucarini, G., Wilkinson, T., Crema, E. R., Palombini, A., Bevan, A., \& Broodbank, C. (2020). The MedAfriCarbon radiocarbon database and web application. Archaeological dynamics in Mediterranean Africa, ca. 9600-700 BC. Journal of Open Archaeology Data, 8(1), 1-6. https://doi.org/10. 5334/joad. 60

Lugliè, C. (2009a). Il Mesolitico. In Atti della XLIV Riunione Scientifica : La preistoria e la protostoria della Sardegna (Cagliari, Barumini, Sassari, 23-28 novembre 2009). Volume I : Relazioni generali (pp.31-36). Istituto Italiano di Preistoria e Protostoria.

Lugliè, C. (2009b). Il Neolitico Antico in Sardegna. In Atti della XLIV Riunione Scientifica : La preistoria e la protostoria della Sardegna (Cagliari, Barumini, Sassari, 23-28 novembre 2009). Volume I : Relazioni generali (pp. 37-47). Istituto Italiano di Preistoria e Protostoria.

Lugliè, C. (2018). Your path led trough the sea ... The emergence of Neolithic in Sardinia and Corsica. Quaternary International, 470, 285-300. https://doi.org/10.1016/J.QUAINT.2017.12.032

Maggi, R., Binder, D., Panelli, C., Gabriele, M., Pearce, M., Rossi, S., \& Rowley-Conwy, P. (2020). Liguria: Aperture e chiusure di un'isola fra due pianure. Rivista di Scienze Preistoriche, 70, 83-97.

Malone, C. (1994). The transition to agriculture. In C. Malone \& S. Stoddart (Eds.), Territory, time, and state: The archaeological development of the Gubbio basin (pp. 67-80). Cambridge University Press.

Malone, C. (2003). The Italian Neolithic: A synthesis of research. Journal of World Prehistory, 17(3), 235-312.

Malone, C., Ayala, G., Fitzjohn, M., \& Stoddart, S. (2003). Under the Volcano. Accordia Research Papers, 9, 7-22.

Malone, C., \& Stoddart, S. (2004). Towards an island of mind? In J. Cherry, C. Scarre, \& S. Shennan (Eds.), Explaining social change: Studies in honour of Colin Renfrew (pp. 93-102). McDonald Institute for Archaeological Research.

Malone, C. (2007). Ritual space and structure-the context of cult in Malta and Gozo. In D. A. Barrowclough \& C. Malone (Eds.), Cult in context: Reconsidering ritual in archaeology (pp. 23-34). Oxbow.

Malone, C., Grima, R., Magro-Conti, J., Trump, D. H., Stoddart, S., \& Hardisty, H. (2009). The domestic environment. In C. Malone, S. Stoddart, A. Bonanno, \& D. H. Trump (Eds.), Mortuary customs in 
prehistoric Malta: Excavations at the Brochtorff Circle at Xagћra (1987-94) (pp. 41-56). McDonald Institute for Archaeological Research.

Malone, C., Brogan, C., Grima, R., Parkinson, E., McLaughlin, T. R., Stoddart, S., \& Vella, N. (2020a). Conclusions. In C. Malone, R. Grima, T. R. McLaughlin, E. W. Parkinson, S. Stoddart, \& N. Vella (Eds.), Temple places: Excavating cultural sustainability in prehistoric Malta (Volume 2 of the ERC-funded FRAGSUS Project) (pp. 457-481). McDonald Institute for Archaeological Research.

Malone, C., McLaughlin, T. R., Armstrong, S., Bennett, J., McAdams, C., French, C., Stoddart, S., \& Cutajar, N. (2020b). Excavations at Tac்-Cawla, Rabat, Gozo, 2014. In C. Malone, R. Grima, T. R. McLaughlin, E. W. Parkinson, S. Stoddart, \& N. Vella (Eds.), Temple places: Excavating cultural sustainability in prehistoric Malta (Volume 2 of the ERC-funded FRAGSUS Project) (pp. 39-122). McDonald Institute for Archaeological Research.

Malone, C., \& Stoddart, S. (Eds.). (1994a). Territory, time and state: The archaeological development of the Gubbio basin. Cambridge University Press.

Malone, C., Stoddart, S., Barker, G., Coltorti, M., Costantini, L., Giorgi, J., Clark, G., Harding, J., Hunt, C., Reynolds, T., \& Skeates, R. (1992). The Neolithic site of San Marco, Gubbio (Perugia), Umbria: Survey and excavation, 1985-7. Papers of the British School at Rome, 60, 1-69.

Malone, C., Stoddart, S., \& Trump, D. H. (1988). A house for the temple builders: Recent investigations on Gozo, Malta. Antiquity, 62(235), 297-301.

Malone, C., Stoddart, S., \& Whitehouse, R. D. (1994b). The Bronze Age of southern Italy, Sicily and Malta c. 2000-800 BC. In C. Mathers \& S. Stoddart (Eds.), Development and decline in the Mediterranean Bronze Age (pp. 167-194). J. R. Collis.

Manfredini, A. (2014). Abitare nell'eneolitico: Il caso di Maddalena di Muccia. In G. Baldelli \& F. Lo Schiavo (Eds.), Amore per l'Antico: Dal Tirreno all'Adriatico, della Preistoria al Medioevo e oltre. Studi di antichità in ricordo di Giuliano do Marinis (pp. 379-386). Scienze e Lettere.

Manfredini, A., Fugazzola Delpino, M. A., Sarti, L., Silvestrini, M., \& Martini, F. (2009). Adriatico e Tirreno a confronto: Analisi dell'occupazione territoriale tra il Neolitico finale e l'età del rame in alcune aree campione dell'Italia centrale. Rivista Di Scienze Preistoriche, 59(1), 115-179.

Manning, K., \& Timpson, A. (2014). The demographic response to Holocene climate change in the Sahara. Quaternary Science Reviews, 101, 28-35. https://doi.org/10.1016/j.quascirev.2014.07.003

Manunza, M. R., Fenu, P., \& Nieddu, F. (2014). Approcci allo studio delle architetture domestiche di facies Monte Claro: L'abitato del Lago di Monte Pranu-Tratalias/Villaperuccio (CI). Quaderni, 25, 33-55.

Marcus, J. H., Posth, C., Ringbauer, H., et al. (2020). Genetic history from the Middle Neolithic to present on the Mediterranean island of Sardinia. Nature Communications, 11, 939.

Martínez-Grau, H., Jagher, R., Oms, F. X., Barceló, J. A., Pardo-Gordó, S., \& Antolín, F. (2020). Global processes, regional dynamics? Radiocarbon data as a proxy for social dynamics at the end of the Mesolithic and during the early Neolithic in the NW of the Mediterranean and Switzerland (c. 6200-4600 cal. BC). Documenta Praehistorica, 47, 170-191.

Martínez Sánchez, M., Martín de la Cruz, J., Tusa, S., Jiménez, L., \& Ingoglia, A. (2016). New contribution to absolute dating of the monumental Neolithic ditch-trench of Stretto-Partanna (Trapani, Sicily). Trabajos De Prehistoria, 73, 315-324.

Martini, F., Lo Vetro, D., Colonese, A. C., De Curtis, O., Di Giuseppe, Z., Locatelli, E., \& Sala, B. (2007). L'Epigravettiano finale in Sicilia. In F. Martini (Ed.), L'Italia tra 15000 e 10000 anni fa: Cosmopolitismo e regionalità nel Tardoglaciale (Atti della Tavola rotonda, Firenze 18 novembre 2005) (pp. 209-253). Museo Fiorentino di Preistoria.

McLaughlin, T. R. (2019). On applications of space-time modelling with open-source 14C age calibration. Journal of Archaeological Method and Theory, 26, 479-501. https://doi.org/10.1007/ s10816-018-9381-3

McLaughlin, T. R., French, C., Parkinson, E. W., Boyle, S., Bennett, J., Stoddart, S., \& Malone, C. (2020a). Santa Verna. In C. Malone, R. Grima, T. R. McLaughlin, E. W. Parkinson, S. Stoddart, \& N. Vella (Eds.), Temple places: Excavating cultural sustainability in prehistoric Malta (Volume 2 of the ERC-funded FRAGSUS Project) (pp. 123-169). McDonald Institute for Archaeological Research.

McLaughlin, T. R., Parkinson, E. W., Reimer, P., \& Malone, C. (2020b). Dating Maltese prehistory. In C. Malone, R. Grima, T. R. McLaughlin, E. W. Parkinson, S. Stoddart, \& N. Vella (Eds.), Temple places: Excavating cultural sustainability in prehistoric Malta (Volume 2 of the ERC-funded FRAGSUS Project) (pp. 27-38). McDonald Institute for Archaeological Research. 
McLaughlin, T. R., Whitehouse, N. J., Schulting, R. J., McClatchie, M., Barratt, P., \& Bogaard, A. (2016). The changing face of Neolithic and Bronze Age Ireland: A big data approach to the settlement and burial Records. Journal of World Prehistory, 29(2), 117-153. https://doi.org/10.1007/ s10963-016-9093-0

Melis, M. G. (2000). L'Età del Rame in Sardegna: Origine ed evoluzione degli aspetti autoctoni. Villanova Monteleone: Soter Editrice.

Melis, M. G. (2009). L'Eneolitico antico, medio ed evoluto in Sardegna: Dalla fine dell'Ozieri all'Abealzu. In Atti della XLIV Riunione Scientifica : La preistoria e la protostoria della Sardegna (Cagliari, Barumini, Sassari, 23-28 novembre 2009). Volume I : Relazioni generali (pp. 81-95). Istituto Italiano di Preistoria e Protostoria.

Melis, M. G. (2013). Problemi di cronologia insulare: La Sardegna tra il IV e il III millennio BC. In D. Cocchi Genick (Ed.), Cronologia assoluta e relativa dell'età del rame in Italia (Atti dell'incontro di studi Universita di Verona, 25 June 2013) (pp. 197-211). QuiEdit.

Melis, M. G. (2014). Sardinian prehistoric burials in a Mediterranean perspective: Symbolic and socioeconomic aspects. In B. Schulz Paulsson \& B. Gaydarska (Eds.), Neolithic and Copper Age monuments: Emergence, function and the social construction of the landscape (pp. 7-21). Oxford: Archaeopress.

Melis, P. (2017). I nuraghi. In A. Moravetti, P. Melis, L. Foddai, \& E. Alba (Eds.), La Sardegna Nuragica: Storia e monumenti (pp. 29-53). Sassari: Regione Autonoma della Sardegna.

Miari, M. (2014). La necropoli eneolitico di Celletta dei Passeri a Forlì. In R. C. De Marinis (Ed.), Atti di Convegno: Le manifestazioni del sacro e l'età del Rame nella regione alpina e nella pianura padana (Brescia, Palazzo Broletto, 23-24 maggio 2014) (pp. 223-238). Euroteam.

Miari, M., \& Benazzi, S. (2018). La necropoli di Gattolino di Cesena (Forlì-Cesena): Nuovi spunti di riflessione. In Quinto Incontro Annuale di Preistoria e Protostoria: Materiali Preziosi, Semipreziosi e Inconsueti nell'Età del Rame e nell'Età del Bronzo Italiana: Archeologia, Archeometria e Paleotecnologia (Università degli Studi di Padova, Padova, 29 Maggio 2018) (pp. 11-16). Istituto di Preistoria e Protostoria.

Miari, M., Bestetti, F., \& Rasi, P. A. (2017). La necropoli eneolitica di Celletta dei Passeri (Forlì): Analisi delle sepolture e dei corredi funerari. Rivista Di Scienze Preistoriche, 67, 145-208.

Minoja, M., \& Usai, A. (Eds.). (2015). Le sculture di Mont'e Prama: Contesto, scavi e materiali. Gangemi Editore.

Modi, A., Tassi, F., Susca, R. R., Vai, S., Rizzi, E., De Bellis, G., Lugliè, C., Fortes, G. G., Lari, M., Barbujani, G., Caramelli, D., \& Ghirotto, S. (2017). Complete mitochondrial sequences from Mesolithic Sardinia. Scientific Reports. https://doi.org/10.1038/srep42869

Mordant, C. (2013). The Bronze Age in France. In H. Fokkens \& A. Harding (Eds.), The Oxford handbook of the European Bronze Age (pp. 571-593). Oxford University Press. https://doi.org/10.1093/ oxfordhb/9780199572861.013.0032

Morin, J., Lepofsky, D., Ritchie, M., Porčić, M., \& Edinborough, K. (2018). Assessing continuity in the ancestral territory of the Tsleil-Waututh-Coast Salish, southwest British Columbia, Canada. Journal of Anthropological Archaeology, 51, 77-87. https://doi.org/10.1016/J.JAA.2018.04.004

Morter, J. (2010). The Chora of Croton 1: The Neolithic settlement at Capo Alfiere (Ed. J. E. Robb). University of Texas Press.

Mottes, E., Petrucci, G., Rottoli, M., \& Visentini, P. (2009). Evolution of the Square Mouthed Pottery culture in the Trentino-Alto-Adige, Veneto and Friuli: Cultural, chronological, palaeoeconomic and environmental aspects. Gortiana. Geologia, Paleontologia Paletnologia, 31, 97-124.

Natali, E., \& Forgia, V. (2018). The beginning of the Neolithic in southern Italy and Sicily. Quaternary International, 470, 253-269. https://doi.org/10.1016/j.quaint.2017.07.004

Negroni Catacchio, N. (2006). La cultura di Rinaldone. In N. Negroni Catacchio (Ed.), Atti del incontro di studi 77: Pastori e guerrieri nell'Etruria del IV e III millennio a.C-la civiltà di rinaldone a 100 anni dalle prime scoperte (Viterbo, 21 novembre 2003 e Valentano 17-18 settembre 2004) (pp. 31-45). Centro Studi di Preistoria e Archeologia.

Negroni Catacchio, N. (2010). L'alba dell'Etruria: Fenomeni di continuità e trasformazione nei secoli XII-VIII a.C. In N. Negroni Catacchio (Ed.), Atti del Nono Incontro di Studi: L'alba dell'Etruria fenomeni di continuità e trasformazione nei secoli XII-VIII a.C. Ricerche e scavi (Valentano-Pitigliano, 12-14 Settembre 2008 (pp. 23-35). Centro Studi di Preistoria e Archeologia.

Negroni Catacchio, N., Aspesi, M., \& Sala, A. J. (2016). The Chalcolithic culture of Rinaldone: The core area. In O. Rickards \& L. Sarti (Eds.), Biological and cultural heritage of the central-southern Italian population through 30 thousand years (pp. 41-57). UniversItalia. 
Nicolis, F. (2013). Northern Italy. In H. Fokkens \& A. Harding (Eds.), The Oxford handbook of the European Bronze Age (pp. 692-705). Oxford University Press. https://doi.org/10.1093/oxfordhb/97801 99572861.013.0038

Oh, Y., Conte, M., Kang, S., Kim, J., \& Hwang, J. (2017). Population fluctuation and the adoption of food production in prehistoric Korea: Using radiocarbon dates as a proxy for population change. Radiocarbon, 59(6), 1-10.

Orsi, P. (1899). Pantelleria: Risultati di una missione archeologica. Accademia dei Lince.

Orsi, P. (1921). Megara Hyblaea: Villaggio neolitico e tempio greco arcaico e di taluni singolarissimi vasi di Paterno. Monumenti Antichi, 27, 109-180.

Pacciarelli, M. (2000). Dal villaggio alla città: La svolta protourbana del 1000 a.C. nell'Italia Tirrenica. All'Insegna del Giglio.

Pacciarelli, M., Scarano, T., \& Crispina, A. (2015). The transition between the Copper and Bronze Ages in southern Italy and Sicily. In H. Meller, H. W. Arz, R. Jung \& R. Risch (Eds.), 2200 BC-A climatic breakdown as a cause for the collapse of the Old World? (7th Archaeological Conference of Central Germany, October 23-26, 2014, Halle, Saale) (pp. 253-281). Landesmuseums.

Palmisano, A., Bevan, A., Kabelindde, A., Roberts, N., \& Shennan, S. (2021). Long-term demographic trends in prehistoric Italy: Climate impacts and regionalised socio-ecological trajectories. Journal of World Prehistory, 34(3). https://doi.org/10.1007/s10963-021-09159-3

Palmisano, A., Bevan, A., \& Shennan, S. (2017). Comparing archaeological proxies for long-term population patterns: An example from central Italy. Journal of Archaeological Science, 87, 59-72. https://doi.org/10.1016/J.JAS.2017.10.001

Palmisano, A., Bevan, A., \& Shennan, S. (2018). Regional demographic trends and settlement patterns in central Italy: Archaeological sites and radiocarbon dates. Journal of Open Archaeology Data. https://doi.org/10.5334/joad.43

Palmisano, A., Woodbridge, J., Roberts, C. N., Bevan, A., Fyfe, R., Shennan, S., Cheddadi, R., Greenberg, R., Kaniewski, D., Langgut, D., Leroy, S. A. G., Litt, T., \& Miebach, A. (2019). Holocene landscape dynamics and long-term population trends in the Levant. The Holocene, 9(5), 708-727. https://doi.org/10.1177/0959683619826642

Parkinson, E. W., \& McLaughlin, T. R. (2020). Lifeways at the acme of the south Italian Neolithic: New chronological and bio-archaeological data from Fonteviva, Apulia. Journal of Archaeological Science: Reports. https://doi.org/10.1016/j.jasrep.2020.102589

Passariello, I., Albore Livadie, C., Talamo, P., Lubritto, C., D’Onofrio, A., \& Terrasi, F. (2009). 14C Chronology of avellino pumices eruption and timing of human reoccupation of the devastated region. Radiocarbon, 51(2), 803-816. https://doi.org/10.1017/S0033822200056113

Passariello, I., Talamo, P., D’Onofrio, A., Barta, P., Lubritto, C., \& Terrasi, F. (2010). Contribution of radiocarbon dating to the chronology of Eneolithic in Campania (Italy). Geochronometria, 35(1), 25-33. https://doi.org/10.2478/v10003-010-0008-2

Pearce, M. (1998). New research on the terramare of northern Italy. Antiquity, 72(278), 743-746. https:// doi.org/10.1017/S0003598X00087317

Pearce, M. (2013). Rethinking the north Italian Early Neolithic. Accordia Research Institute.

Pearce, M. (2017). The 'island of silver veins': An overview of the earliest metal and metalworking in Sardinia. Metalla, 23(2), 91-11.

Pearce, M. (2019). The 'Copper Age'-A history of the concept. Journal of World Prehistory, 32, $229-250$.

Pearce, M. (2020). Aspects of urbanism in later Bronze Age northern Italy. In L. Zamboni, M. Fernández-Götz, \& A. Metzner-Nebelsick (Eds.), Crossing the Alps: Early urbanism between northern Italy and Central Europe (900-400 BC) (pp. 9-25). Sidestone.

Peche-Quilichini, K., \& Cesari, J. (2017). Les architectures turriformes de l'âge du Bronze en Corse : Structure, chronologie, distribution. In A. Moravetti, P. Melis, L. Foddai, \& E. Alba (Eds.), La Sardegna Nuragica: Storia e monumenti (pp. 171-188). Regione Autonoma della Sardegna.

Perego, E., \& Scopacasa, R. (2016). Burial and social change in first-millennium BC Italy: Approaching social agents, gender, personhood and marginality. Oxbow.

Peroni, R. (2000). Formazione e sviluppo dei centri protourbani medio tirrenici. In R. Peroni (Ed.), L'Italia alle Soglie della Stori (pp. 26-31). Laterza.

Peroni, R., \& Trucco, F. (Eds.). (1994). Enotri e Micenei nella Sibaritide. Taranto: Istituto per la storia e l'Archeologia della magna Grecia.

Peros, M. C., Munoz, S. E., Gajewski, K., \& Viau, A. E. (2010). Prehistoric demography of North America inferred from radiocarbon data. Journal of Archaeological Science, 37(3), 656-664. 
Perrin, T., \& Manen, C. (2021). Potential interactions between Mesolithic hunter-gatherers and Neolithic farmers in the Western Mediterranean: The geochronological data revisited. PLoS ONE. https:// doi.org/10.1371/journal.pone.0246964

Pessina, A., \& Tinè, V. (2018). Archeologia del Neolitico: L'Italia tra VI e IV millennio a.C. Carocci.

Pinhasi, R., Fort, J., \& Ammerman, A. J. (2005). Tracing the origin and spread of agriculture in Europe. PLoS Biology. https://doi.org/10.1371/journal.pbio.0030410

Pluciennik, M. (1994). Holocene hunter-gatherers in Italy. In R. Skeates \& R. D. Whitehouse (Eds.), Radiocarbon dating and Italian prehistory (pp. 45-60). British School at Rome.

Pluciennik, M. (1997). Radiocarbon determinations and the Mesolithic-Neolithic transition in Southern Italy. Journal of Mediterranean Archaeology, 10(2), 115-150.

Pluciennik, M. (2008). The coastal Mesolithic of the European Mediterranean. In G. Bailey., \& P. Spikins (Eds.), Mesolithic Europe (pp. 328-356). Cambridge University Press.

Price, T. D. (2013). Europe before Rome: A site-by-site tour of the Stone, Bronze, and Iron Ages. Oxford University Press.

Procelli, E. (1996). Sicily between the second and third millennium BC: A brief survey. In R. Leighton (Ed.), Early societies in Sicily (pp. 89-100). Accordia Research Institute.

Putzer, A., Festi, D., Edlmair, S., \& Oeggl, K. (2016). The development of human activity in the high altitudes of the Schnals Valley (South Tyrol/Italy) from the Mesolithic to modern periods. Journal of Archaeological Science: Reports, 6, 136-147.

Quarta, G., Tiberi, I., Rossi, M., Aprile, G., Braione, E., D’Elia, M., Ingravallo, E., \& Calcagnile, L. (2014). The Copper Age mound necropolis in Salve, Lecce, Italy: Radiocarbon dating desults on charcoals, bones, cremated bones, and pottery. Radiocarbon, 56(3), 949-957.

Radi, G., \& Petrinelli Pannocchia, C. (2018). The beginning of the Neolithic era in central Italy. Quaternary International, 470, 270-284. https://doi.org/10.1016/J.QUAINT.2017.06.063

Renfrew, C. (1971). Malta and the calibrated radiocarbon chronology. Antiquity, 45(182), 141-144.

Reimer, P., Austin, W., Bard, E., Bayliss, A., Blackwell, P., Bronk Ramsey, C., Butzin, M., Cheng, H., Edwards, L., Friedrich, F., Grootes, P., Guilderson, T., Hajdas, I., Heaton, T., Hogg, A., Hughen, K., Kromer, B., Manning, S., Muscheler, R., Palmer, J., et al. (2020). The IntCal20 northern hemisphere radiocarbon age calibration curve (0-55 cal kBP). Radiocarbon, 62(4), 725-757.

Rick, J. W. (1987). Dates as data: An examination of the Peruvian preceramic radiocarbon record. American Antiquity, 52(1), 55. https://doi.org/10.2307/281060

Riris, P. (2018). Dates as data revisited: A statistical examination of the Peruvian preceramic radiocarbon record. Journal of Archaeological Science, 97, 67-76. https://doi.org/10.1016/J.JAS.2018.06.008

Riva, C. (2010). The urbanisation of Etruria: Funerary practice and social change, 700-600 BC. Cambridge University Press.

Robb, J. E. (2001). Island identities: Ritual, travel and the creation of difference in Neolithic Malta. European Journal of Archaeology, 4(2), 175-202.

Robb, J. E. (2007). The early Mediterranean village: Agency, material culture, and social change in Neolithic Italy. Cambridge University Press.

Rondelli, B. (2008). Complexity before cities: Expansion and social transformation in the Po Valley (Italy) during the Bronze Age and Early Iron Ages. In I. Akira (Ed.), Kingship and city culture (International Centre for Japanese Studies 33rd International Research Symposium, Kyoto, 6-8th March, 2008) (pp. 23-41). International Center for Japanese Studies.

Russell, J. C. (1958). Late ancient and medieval population. Transactions of the Americian Philosophical Society, 48(3), 1-152.

Sagona, C. (2015). The archaeology of Malta: From the Neolithic through the Roman period. Cambridge University Press.

Salerno, A., \& Marino, P. (2011). La necropoli dell'area Forum di Gricignano d'Aversa (Caserta) US Navy: Composizione e articolazione dei contesti tombali di facies Laterza. In D. Cocchi Genick (Ed.), Atti della XLIII riunione scientifica IIPP: L'età del rame in Italia (Bologna, 26-29 novembre 2008). dedicata a Gianni Bailo Modesti (pp. 323-327). Istituto Italiano di Preistoria e Protostoria.

Saupe, T., Montinaro, F., Scaggion, C., Carrara, N., Kivisild, T. et al. (2021). Ancient genomes reveal structural shifts after the arrival of steppe-related ancestry in the Italian Peninsula. Current Biology. https://doi.org/10.1016/j.cub.2021.04.022

Scoz, L., Cavulli, F., Fedrigotti, A., Neri, S., Pedrotti, A., \& Dalmeri, G. (2015). New data on the first human settlements in western Trentino: The site of Pozza Lavino in the Ledro valley (Trentino, Italy). Quaternary International, 423, 40-57. https://doi.org/10.1016/j.quaint.2015.11.112 
Shennan, S., Downey, S., Timpson, A., Edinborough, K., Colledge, S., Kerig, T., Manning, K., \& Thomas, M. G. (2013). Regional population collapse followed initial agriculture booms in midHolocene Europe. Nature Communications. https://doi.org/10.1038/ncomms3486

Shennan, S., \& Edinborough, K. (2007). Prehistoric population history: From the Late Glacial to the Late Neolithic in central and northern Europe. Journal of Archaeological Science, 34(8), 1339-1345. https://doi.org/10.1016/J.JAS.2006.10.031

Silva, F., \& Vander Linden, M. (2017). Amplitude of travelling front as inferred from 14C predicts levels of genetic admixture among European early farmers. Scientific Reports. https://doi.org/10.1038/ s41598-017-12318-2

Silvestrini, M., \& Pignocchi, G. (1997). The Eneolithic necropolis of Fontenoce/Guzzini area. Preistoria Alpina, 33, 11-14.

Skeates, R. (1994). A radiocarbon date-list for prehistoric Italy (c.46,400 BP-2450 BP/400 cal.BC). In R. Skeates \& R. D. Whitehouse (Eds.), Radiocarbon dating and Italian prehistory (pp. 147-388). British School at Rome.

Skeates, R. (1996). Towards an absolute chronology for the Copper Age in central Italy: A note based on the Conelle site and culture. Papers of the British School at Rome, 64, 273-282.

Skeates, R. (1997). Copper Age settlement and economy in Marche, central Italy: A social perspective. Journal of Mediterranean Archaeology, 10(1), 49-72.

Skeates, R. (1998). New radiocarbon dates for prehistoric Italy 3. Accordia Research Papers, 7, 149-162.

Skeates, R. (2000a). New radiocarbon dates for prehistoric Italy and Malta: Supplementary list 4. Accordia Research Papers, 8, 165-186.

Skeates, R. (2000b). The social dynamics of enclosure in the Neolithic of the Tavoliere, south-east Italy. Journal of Mediterranean Archaeology, 13, 155-188.

Skeates, R. (2003). New radiocarbon dates for prehistoric Italy: Supplementary list 5. Accordia Research Papers, 5, 163-181.

Skeates, R. (2013). Neolithic Italy at 4004 BC: People and places. Accordia Research Papers, 13. Special issue: Rethinking the Italian Neolithic, 1-29. https://doi.org/10.1063/1.2756072

Skeates, R. (2015). Italian enclosures. In C. Fowler, J. Harding, \& D. Hofmann (Eds.), The Oxford handbook of Neolithic Europe (pp. 779-793). Oxford University Press. https://doi.org/10.1063/1.27560 72

Skeates, R., \& Whitehouse, R. D. (1994a). New radiocarbon dates for prehistoric Italy 1. Accordia Research Papers, 5, 137-150.

Skeates, R., \& Whitehouse, R. D. (1994b). Radiocarbon dating and Italian prehistory. The British School at Rome.

Skeates, R., \& Whitehouse, R. D. (1996). New radiocarbon dates for prehistoric Italy 2. Accordia Research Papers, 6, 179-191.

Speciale, C. (2011). La facies di San Cono-Piano Notaro-Grotta Zubbia nel quadro delle relazioni con l'Egeo nel primo eneolitico siciliano. In D. Cocchi Genick (Ed.), Atti della XLIII riunione scientifica IIPP: L'età del rame in Italia (Bologna, 26-29 novembre 2008). Dedicata a Gianni Bailo Modesti (pp. 489-493). Istituto Italiano di Preistoria e Protostoria.

Spindler, K. (2000). Der Mann im Eis: Neue sensationelle Erkenntnisse über die Mumie in den ötztaler Alpen. Goldman.

Starnini, E., Biagi, P., \& Mazzucco, N. (2018). The beginning of the Neolithic in the Po Plain (northern Italy): Problems and perspectives. Quaternary International, 470, 270-284. https://doi.org/10. 1016/j.quaint.2017.05.059

Stoddart, S. (2010). Boundaries of the state in time and space: Transitions and tipping Points. Social Evolution \& History, 9(2), 28-52.

Stoddart, S. (2020a). Power and place in Etruria: The spatial dynamics of a Mediterranean civilisation, 1200-500 BC. Cambridge University Press.

Stoddart, S. (2020b). An Etruscan urban agenda: The weaving together of traditions. Journal of Urban Archaeology, 1, 88-121.

Stoddart, S. (2020c). Untold riches of the urban form central to the pre-Roman European experience. In L. Zamboni, M. Fernández-Götz, \& C. Metzner-Nebelsick (Eds.), Crossing the Alps: Early urbanism between northern Italy and central Europe (900-400 BC) (pp. 427-450). Sidestone.

Stoddart, S., Bonanno, A., Gouder, T., Malone, C., \& Trump, D. H. (1993). Cult in an island society: Prehistoric Malta in the Tarxien period. Cambridge Archaeological Journal, 3(1), 3-19.

Stoddart, S., Palmisano, A., Redhouse, D., Barker, G., di Paola, G., Motta, L., Rasmussen, T., Samuels, T., \& Witcher, R. (2020). Patterns of Etruscan urbanism. In F. Fulminante, J. W., Hanson, S. 
Ortman, \& L. M. Bettencourt (Eds.), Where do cities come from and where are they going to? Modelling past and present agglomerations to understand urban ways of life. Frontiers Digital Humanities (Digital Archaeology) (Vol. 7, No. 1). https://doi.org/10.3389/fdigh.2020.00001

Stoddart, S., Woodbridge, J., Palmisano, A., Mercuri, A. M., Mensing, S. A., Colombaroli, D., Sadori, L., Magri, D., Di Rita, F., Giardini, M., Lippi, M. M., Montanari, C., Bellini, C., Florenzano, A., Torri, P., Bevan, A., Shennan, S., Fyfe, R., \& Roberts, C. N. (2019). Tyrrhenian central Italy: Holocene population and landscape ecology. The Holocene, 29(5), 761-777. https://doi.org/10.1177/ 0959683619826696

Surovell, T., Finley, J., Smith, G., Brantingham, P. J., \& Kelly, R. (2009). Correcting temporal frequency distributions for taphonomic bias. Journal of Archaeological Science, 36(8), 1715-1724. https:// doi.org/10.1016/j.jas.2009.03.029

Tagliacozzo, A. (1994). Economic changes between the Mesolithic and the Neolithic in the Grotta dell'Uzzo (Sicily, Italy). Accordia Research Papers, 5, 7-38.

Talamo, P. (1996). Elementi per una definizione culturale della facies di Palma Campania. In D. Cocchi Genick (Ed.), L'antica età del Bronzo in Italia: Atti del Convegno nazionale (Viareggio 9-12 gennaio 1995) (pp. 119-134). Octavo, F. Cantini.

Talamo, P. (2006). L'aspetto campano di Laterza in Irpinia. In A. Gravina (Ed.), $26^{\circ}$ Convegno Nazionale sulla Preistoria-Protostoria-Storia della Daunia (San Severo 10-11 dicembre 2005) (pp. 83-96). Centro Grafico.

Tanasi, D. (2014). Lighting up the dark: The role of ghar Mirdum in Maltese prehistory. In D. Gullì (Ed.), From cave to dolmen: Ritual and symbolic aspects in the prehistory between Sciacca, Sicily and the central Mediterranean (pp. 287-308). Archaeopress.

Tanasi, D., \& Vella, N. C. (Eds.). (2011). Site, artefacts and landscape: Prehistoric Borg in-Nadur, Malta. Monza: Polimetrica.

Thompson, J., Parkinson, E., McLaughlin, T., Barrat, R., Power, R., Mercieca-Spiteri, B., Stoddart, S., \& Malone, C. (2020). Placing and remembering the dead in late Neolithic Malta: Bioarchaeological and spatial analysis of the Xaghra Circle Hypogeum, Gozo. World Archaeology, 52(1), 71-89.

Timpson, A., Colledge, S., Crema, E., Edinborough, K., Kerig, T., Manning, K., Thomas, M. G., \& Shennan, S. (2014). Reconstructing regional population fluctuations in the European Neolithic using radiocarbon dates: A new case-study using an improved method. Journal of Archaeological Science, 52, 549-557.

Tinè, S. (1960). Giacimenti dell'età rame in sicilia e la 'cultura tipo conca d'oro.' Bullettino Di Paletnologia Italiana, 69(13), 113-151.

Tinè, S. (1983). Passo di Corvo e la civiltà neolitica del Tavoliere. Sagep.

Torfing, T. (2015). Neolithic population and summed probability distribution of 14 C-dates. Journal of Archaeological Science, 63, 193-198. https://doi.org/10.1016/j.jas.2015.06.004

Tronchetti, C. (2015). Cultural interactions in Iron Age Sardinia. In A. B. Knapp \& P. van Dommelen (Eds.), The Cambridge prehistory of the Bronze and Iron Age Mediterranean (pp. 266-284). Cambridge University Press. https://doi.org/10.1017/CHO9781139028387.020

Trump, D. H. (1961). Skorba, Malta and the Mediterranean. Antiquity, 35(140), 300-303.

Trump, D. H. (1966a). Central and southern Italy before Rome. Thames \& Hudson.

Trump, D. H. (1966b). Skorba: Excavations carried out on behalf of the National Museum of Malta 1961-1963. Society of Antiquaries of London.

Trump, D. H. (1980). The prehistory of the Mediterranean. Allen Lane.

Trump, D. H. (1987) [1963]. The excavated sites. In G. D. B. Jones (Ed.), Apulia Vol. I: Neolithic settlement in the Tavoliere (pp. 117-135). Society of Antiquaries of London.

Trump, D. H. (1995). Radiocarbon dating and Italian prehistory by R. Skeates and R. Whitehouse (review). Journal of Mediterranean Studies, 5(1), 144-147.

Trump, D. H. (1996). Radiocarbon dates from Malta. Accordia Research Papers, 6, 173-178.

Trump, D. H. (2002). Malta: Prehistory and Temples. Midsea Books.

Trump, D. H. (2015). Skorba, 1961-63 excavations: A revisit to the report and site after 50 years. Gutenberg Press.

Tunzi, A. M., Matteo Martino, F., Gasperi, N., Bubba, D., \& de Armentia, M. (2013). L'insediamento dell'età del Rame di Tegole (Bovino, Foggia). In D. Cocchi Genick (Ed.), Cronologia assoluta e relativa dell'età del rame in Italia (Atti dell'incontro di studi Università di Verona, 25 June 2013) (pp. 137-148.). QuiEdit. 
Tunzi, A. M., Lo Zupone, M., Bubba, D., \& Gasperi, N. (2017). Strutture di abitato e aree produttive dell'età del Rame nella Puglia settentrionale. In F. Radina (Ed.), Preistoria e protostoria della Puglia (pp. 2-7). Istituto Italiano di Preistoria e Protostoria.

Tykot, R. H. (1994). Radiocarbon dating and absolute chronology in Sardinia and Corsica. In R. Skeates \& R. D. Whitehouse (Eds.), Radiocarbon dating and Italian Prehistory (pp. 115-146). British School at Rome.

Ucchesu, M., Sau, S., \& Lugliè, C. (2017). Crop and wild plant exploitation in Italy during the Neolithic period: New data from Su Mulinu Mannu, Middle Neolithic site of Sardinia. Journal of Archaeological Science: Reports, 14, 1-11. https://doi.org/10.1016/j.jasrep.2017.05.026

UN (2015). United Nations Department for Economic and Social Affairs 'The world population prospects: 2015 revision' available from http://www.un.org/en/development/desa/publications/ world-population-prospects-2015-revision.html (Accessed February 2019)

van der Plicht, J., Bruins, H. J., \& Nijboer, A. J. (2009). The Iron Age around the Mediterranean: A high chronology perspective from the Groningen radiocarbon database. Radiocarbon, 51(1), 213-242. https://doi.org/10.1017/S0033822200033786

Vanzetti, A. (2013). 1600? The rise of the terramara system (northern Italy). In H. Meller, F. Bertemes, H. R. Bork \& R. Risch (Eds.), 1600_Cultural change in the shadow of the Thera Eruption? (4th Archaeological Conference of central Germany, October 14-16, 2011, Halle) (pp. 267-282). Landesmuseums.

Vigne, J. (1998). Preliminary results on the exploitation of animal resources in Corsica during the pre-Neolithic. In M. S. Balmuth \& R. H. Tykot (Eds.), Sardinian and Aegean chronology: Proceedings of the International Colloquium 'Sardinian stratigraphy and Mediterranean chronology (Tufts University, Medford, Massachusetts, March 17-19, 1995) (pp. 57-62). Oxbow.

Visentin, D., Angelucci, D. E., Berruti, G., Bertola, S., Leis, M., Marchesini, M., Marvelli, S., Pezzi, M., Rizzoli, M., Hohenstein, U. T., Ziggiotti, S., \& Fontana, F. (2016). First evidence of human peopling in the southern Po plain after the LGM: The early Sauveterrian site of Collecchio (Parma, northern Italy). Preistoria Alpina, 48, 115-128.

Visentin, D., \& Carrer, F. (2017). Evaluating Mesolithic settlement patterns in mountain environments (Dolomites, eastern Italian Alps): The role of research biases and locational strategies. Archeologia e Calcolatori, 28, 129-145. https://doi.org/10.19282/AC.28.1.2017.08

Visentin, D., Fontana, F., \& Bertola, S. (2014). An atypical early Mesolithic occupation in the southern Po Plain: Evidence from the site of Collecchio (Parma, Italy). In A. Henry, B. Marquebielle, L. Chesnaux \& S. Michel (Eds.), Techniques and territories: New insights into Mesolithic cultures: Proceedings of the round table (November 22-23 2012, Maison de la recherche, Toulouse (France) $A N)$ (pp. 123-128). Palethnologie Association.

Visentini, P. (2006). Aspetti cronologici e culturali della fine del Neolitico nell'Italia nord-orientale. Preistoria Dell'italia Settentrionale, 242, 225-242.

Von Eles, P., \& Pacciarelli, M. (2018). La Romagna dal Bronzo Finale alla prima età del Ferro. In M. Bernabò Brea (Ed.), Preistoria e protostoria dell'Emilia Romagna (vol. II, età del Bronzo, età del Ferro) (pp. 229-244). Istituto Italiano di Preistoria e Protostoria.

Webster, G. (2015). The archaeology of Nuragic Sardinia. Equinox.

Webster, G., \& Webster, M. (2017). Punctuated insularity: The archaeology of 4th and 3rd millennium Sardinia. Britsh Archaeological Reports.

Weiberg, E., Bevan, A., Kouli, K., Katsianis, M., Woodbridge, J., Bonnier, A., Engel, M., Finné, M., Fyfe, R., Maniatis, Y., Palmisano, A., Panajiotidis, S., Roberts, C. N., \& Shennan, S. (2019). Longterm trends of land use and demography in Greece: A comparative study. The Holocene, 29(5), 742-760.

Whitehouse, R. (2001). Investigating surface archaeology on the Po flood plain, northern Italy. Archaeology International, 5, 21-24. https://doi.org/10.5334/ai.0507

Whitehouse, R. D. (1986). Siticulosa Apulia revisited. Antiquity, 60(228), 36-44.

Whitehouse, R. D. (2013). The chronology of the Neolithic ditched settlements of the Tavoliere and the Ofanto valley. Accordia Research Papers: Rethinking the Italian Neolithic, 13, 57-78.

Whitehouse, R. D., \& Renfrew, C. (1974). The Copper Age of peninsular Italy and the Aegean. The Annual of the British School at Athens, 69, 343-390.

Williams, A. N. (2012). The use of summed radiocarbon probability distributions in archaeology: A review of methods. Journal of Archaeological Science, 39(3), 578-589. 
Zahid, H. J., Robinson, E., \& Kelly, R. L. (2016). Agriculture, population growth, and statistical analysis of the radiocarbon record. Proceedings of the National Academy of Sciences of the United States of America, 113(4), 931-935. https://doi.org/10.1073/pnas.1517650112

Zamboni, L. (2021). The urbanization of northern Italy: Contextualizing early settlement nucleation in the Po Valley. Journal of Archaeological Research. https://doi.org/10.1007/s10814-020-09151-z

Publisher's Note Springer Nature remains neutral with regard to jurisdictional claims in published maps and institutional affiliations.

\section{Authors and Affiliations}

\section{Eóin W. Parkinson ${ }^{1}(1) \cdot$ T. Rowan McLaughlin ${ }^{2,3}$ (1) $\cdot$ Carmen Esposito $^{3}$. Simon Stoddart ${ }^{4}$. Caroline Malone ${ }^{3}$}

Eóin W. Parkinson

ewparkinson24@gmail.com

$\triangle$ T. Rowan McLaughlin

rmclaughlin@britishmuseum.org

1 Department of Classics and Archaeology, University of Malta, Msida MSD 2080, Malta

2 British Museum, London, UK

3 School of Natural and Built Environment, Queen's University Belfast, Belfast, UK

4 Department of Archaeology, University of Cambridge, Cambridge, UK 